\title{
Recycling of beverage cartons in the Netherlands 2016
}

Technical report

dr. E.U. Thoden van Velzen, D. Huremović MSc, Ir. E.R.P. Keijsers, Ing. R. op den Kamp Ir. M.T. Brouwer

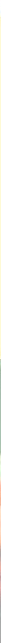




\section{Colophon}

Title Recycling of beverage cartons in the Netherlands 2016, Technical report

Author(s) dr. E.U. Thoden van Velzen, D. Huremović MSc., Ir. E.R.P. Keijsers,

Number $\quad$ Ing.

ISBN-number $\quad 978-94-6343-824-7$

DOI https://doi.org/10.18174/427248

Date of publication 17 November 2017

Version Final

Confidentiality Public

OPD code $\quad 16620453$

Approved by Nicole Koenderink

Review Internal

Name reviewer Martien van den Oever

Sponsor Stichting Afvalfonds Verpakkingen

Client Stichting Afvalfonds Verpakkingen via REBEL

Wageningen Food \& Biobased Research

P.O. Box 17

NL-6700 AA Wageningen

Tel: +31 (0)317480084

E-mail: info.fbr@wur.nl

Internet: www.wur.nl/foodandbiobased-research

(C) Wageningen Food \& Biobased Research, institute within the legal entity Stichting Wageningen Research All rights reserved. No part of this publication may be reproduced, stored in a retrieval system of any nature, or transmitted, in any form or by any means, electronic, mechanical, photocopying, recording or otherwise, without the prior permission of the publisher. The publisher does not accept any liability for inaccuracies in this report. 


\section{Abstract}

In 2016-2017 an independent, technical study has been conducted to describe the Dutch beverage carton recycling system for the year 2016. This study has been commissioned by the three Framework treaty parties and was financed by Stichting Afvalfonds. This is a follow-up study of the large pilot study performed in 2013. In 2016, 93\% of the population of the Netherlands had access to separate collection schemes for beverage cartons and/or their mixed MSW was subjected to mechanical recovery. The dominant collection scheme was the so-called PMD system (a co-collection system of plastics, beverage cartons and metals), followed by PDco-collection (plastics and beverage cartons), mechanical recovery and mono-collection of beverage cartons. A limited amount of inhabitants (almost 7\%) did not have access to a collection scheme for beverage cartons (this is named: mono-plastic collection scheme).

In order to describe these collection and recycling systems, 33 samples were taken from the systems, sorted and analysed. The focus was on the new and now dominant PMD collection \& recycling system. Additionally a material flow analysis with data reconciliation was performed to describe the sorting of beverage cartons from mixed input separate collection systems (Mono-P, $\mathrm{PD}$ and PMD). The average sorting yield was found to be $73 \pm 5 \%$. With the recycling yields established in 2013 the material flow schemes were calculated and net material yields were derived for the 5 main collection \& recycling schemes. Originally it was planned to determine the yields at the newest recycling facility in 2017 . However, this proved impossible due to problems with the feedstock quality.

The expansion of the collection methods for beverage cartons between 2013 and 2016 was reflected in substantial amounts of sorted beverage cartons being produced and traded to recycling facilities. Roughly 20 kton of gross sorted products were generated from separately collected materials in 2016, compared to an approximate $60 \mathrm{kton}$ net national potential of beverage cartons. In contrast the net material chain yields hardly grew between 2013 and 2016, they are still roughly the same as those measured during the pilot of 2013. These net material chain yields (with respect to paper fibre) varied from $18 \pm 3 \%$ for the PD-system, to $24 \pm 2 \%$ for the mono-collection system, $24 \pm 4 \%$ for the PMD-system and finally $38 \pm 7 \%$ for the mechanical recovery system.

Storage experiments with Dutch beverage cartons at specific conditions showed that the quality of the recycled paper fibres is not affected by the storage time (up to 4 weeks) and temperature $\left(4,20\right.$ and $40^{\circ} \mathrm{C}$ ). The fibres are most likely well-protected within the plastic sheets for fungal degradation. The fibres, their products and the pulping water do, however, smell strongly. Directly after pulping the beverage cartons a strong, pungent smell is released. This strong odour was generated when recycling beverage cartons that were 'freshly sorted' and was generated in similar strengths at all subsequent recycling tests during the total experiment (4 weeks). It is difficult to remove this undesired odour from the fibres, their products and the pulping water. 
The cause of this smell is most likely the microbial decomposition of the product residues contained within the cartons, which are released upon recycling.

The quality of the sorted beverage carton products has declined between 2013 and 2017. The sorted products in 2016-2017 contained on average more residual waste than in 2013. This lower quality has most likely multiple reasons: raised levels of residual waste in the collected materials and adjusted sorting policies. This lower quality of sorted products makes the recycling increasingly difficult. This feedstock smells strongly and is infested predominantly with flies. Of the three recycling facilities, one temporarily stopped with processing Dutch beverage cartons during the summer of 2017, one has limited its in-take and the third facility processed most of them under the conditions of just-in-time delivery and direct conversion (zero stock on the yard that could upset the neighbourhood). Quality-wise this is a collection \& recycling chain that is balancing on the edge.

Cross-contamination from beverage cartons to other co-collected packages is not detectable in loose collected material. It presumably occurs only after the material is pressed in either a transport vehicle or during baling of the sorted products. Cross-contamination is, however, most likely not the only cause for the drop in quality of the sorted products, observed between 2013 and 2017. The rise in the amount of residual waste in the collected material, the longer logistical lead-times and the changed sorting policies are all likely causes as well. 


\section{Uitgebreide samenvatting}

In 2016-2017 is er een onafhankelijke, technische studie verricht naar de inzamel \& recyclingketens voor drankenkartons voor het jaar 2016. Deze studie werd aangevraagd door de drie Raamovereenkomstpartijen en werd gefinancierd door Stichting Afvalfonds. Dit is een vervolgstudie na de uitgebreide pilot van 2013. In 2016 was 93\% van de Nederlandse bevolking aangesloten aan een gescheiden inzamelsysteem en/of nascheiding-systeem voor drankenkartons. Het dominante inzamelsysteem was het zogenoemde PMD systeem (een co-inzamelsysteem voor kunststof, drankenkartons en metaal), gevolgd door het PD systeem ( een co-inzamelsysteem voor kunststof en drankenkartons), nascheiding en mono-inzameling. Een kleine groep inwoners (rond de $7 \%$ ) had geen toegang tot een inzamel- \& recyclingsysteem voor drankenkartons (het mono plastic inzamelsysteem).

Om deze inzamel \& recyclingsystemen te beschrijven werden er 33 monsters genomen van materialen uit deze systemen. Deze monsters werden uitgebreid gesorteerd en geanalyseerd. De nadruk lag hierbij op het nieuwe en nu dominante PMD inzamel- \& recyclingsysteem. Het ingezamelde PMD-materiaal bleek gemiddeld te bestaan uit $13 \pm 4 \%$ drankenkartons, 66 $\pm 9 \%$ kunststof (verpakkingen en niet-verpakkingen), $8 \pm 2 \%$ metalen en $13 \pm 8 \%$ uit restafval. Van de 24 onderzochte PMD monsters van verschillende gemeenten bleken er 3 ongewoon veel restafval $(\sim 30 \%)$ te bevatten, die werden als uitschieters beschouwd. De hoeveelheid restafval in PMD materiaal van 2017 is significant hoger dan het percentage restafval in gescheiden ingezamelde kunststofverpakkingen van voor 2014, waarbij tevens moet worden opgemerkt dat de definitie van restafval voor PMD smaller is (nu geen metalen en drankenkartons) dan die voor kunststofverpakkingen was.

Het ingezamelde PD-materiaal bleek te bestaan uit $16 \pm 7 \%$ drankenkartons, $72 \pm 10 \%$ kunststof, $3 \pm 5 \%$ metalen en $10 \pm 2 \%$ restafval. De samenstelling van het PD materiaal was niet noemenswaardig veranderd sinds de pilot van 2013.

In 2016 werden nog steeds dezelfde soorten drankenkartons op de Nederlandse markt gebracht en was de verdeling hiervan in soorten nagenoeg gelijk aan die van 2013. Ook de verdeling van de hoeveelheden aanhangend vocht- en vuil over de soorten drankenkartons is weinig veranderd. Nog steeds dragen de kartons met 'dikke zuivel' (lees yoghurt, vla en drinkyoghurt) bovengemiddeld veel bij. Tijdens deze studie zijn deze resten in een groter detail onderzocht waarbij er onderscheid werd gemaakt tussen het aangehechte vuil aan de buitenzijde van het drankenkarton en de productresten in het drankenkarton. De productresten bleken dominant en voor meer dan $90 \%$ het vuilgewicht te bepalen.

Verder is de aanwezigheid onderzocht van papier- en kartonverpakkingen die lijken op drankenkartons (chips-kokers, diepvries-doosjes, ijsbekers, etc.). Deze bleken nauwelijks voor te komen in het ingezamelde PMD en PD, de gemiddelde concentratie was $0,3 \pm 0,3 \%$.

Tenslotte werden ook de agglomeraten in het ingezamelde materiaal onderzocht. Dit zijn verschillende verpakkingen die dusdanig in elkaar gedrukt zijn, dat ze nagenoeg niet met menselijke kracht te scheiden zijn. Oorzaken van agglomeraatvorming zijn specifiek 
inzamelgedrag door burgers (de zogenoemde proppers) en het mechanisch persen van ingezameld materiaal. Agglomeraten werden in slechts de helft van de monsters ingezameld materiaal (PMD en PD) aangetroffen. De gemiddelde concentratie was 1,5 $\pm 1,6 \%$. Metaalverpakkingen en kunststofverpakkingen komen het meeste voor in agglomeraten.

In dit project werd het sorteerproces van drankenkartons anders onderzocht dan in de pilot van 2013. Toen was er de mogelijkheid om meerdere sorteerbedrijven uitgebreid te massabalanceren. $\mathrm{Nu}$ werd een beperkt aantal sorteerproducten drankenkarton onderzocht, waaruit bleek dat niet alle sorteerproducten bleken te voldoen aan DKR specificatie 510. De kwaliteit van de sorteerproducten was verslechterd ten opzichte van de pilot in 2013 (hierover later meer). Vervolgens werd er een rekenkundige materiaalstroom-analyse uitgevoerd waarbij de hoeveelheden drankenkartons in de ingezamelde materialen (mono-P, PD en PMD) met de hoeveelheden drankenkartons in de uitgaande sorteerproducten in overeenstemming werden gebracht middels een data-verzoeningsprocedure met STAN software. Hieruit werd afgeleid dat het gemiddelde sorteerrendement in $201673 \pm 5 \%$ bedroeg. Oftewel 73\% van de ingezamelde drankenkartons komen ook echt in het sorteerproduct drankenkartons terecht. Hierbij moet worden opgemerkt dat de kwaliteitsindicator voor de verzoeningsprocedure (DRQ) slechts 0,48 was (op een schaal van 0 tot 1 ) en dus matig. Een betrouwbaarder sorteerrendement kan worden verkregen nadat er aanvullende metingen van de concentraties drankenkartons in de uitgaande sorteerproducten zijn verricht.

Helaas bleek het in de zomer van 2017 niet mogelijk om een nieuw recyclingbedrijf voor drankenkartons te massabalanceren. Daardoor werden in de pilot 2013 bepaalde recyclingrendementen gebruikt voor het berekenen van de materiaalstroomschema's van de 5 inzamel- en \& recyclingsystemen.

De expansie van de inzamelsystemen voor drankenkartons tussen 2013 en 2016 zien we terug in de forse hoeveelheden gesorteerd drankenkarton product die zijn geproduceerd en verhandeld naar recyclingbedrijven in 2016. Grofweg 20 kton bruto sorteerproduct werd gegenereerd uit gescheiden inzamelde materialen in 2016, vergeleken met een nationaal potentiaal van ongeveer 60 kton netto drankenkartons. De netto-materiaal-keten-rendementen (berekend ten aanzien van papiervezel) groeien daarentegen nauwelijks tussen 2013 en 2016. Deze netto-materiaal-ketenrendementen varieerden van $18 \pm 5 \%$ voor het PD systeem, tot $24 \pm 2 \%$ voor het monoinzamelsysteem, $24 \pm 7 \%$ voor het PMD inzamelsysteem en tenslotte $38 \pm 7 \%$ voor het nascheiding-systeem. Hierbij moet worden opgemerkt dat er PMD-sub-inzamelsystemen aan te wijzen zijn met fors hogere inzamelrendementen en dus ook netto-materiaal-keten-rendementen. Voor bijvoorbeeld gemeenten met minder dan 50\% hoogbouwwoningen die PMD inzamelen met een haalsysteem en een diftar-regime hanteren voor het restafval bedraagt het nettomateriaal-keten-rendement $37 \pm 4 \%$. In 2016 werden dus de meeste drankenkartons nog niet gescheiden ingezameld en/of nagescheiden. Deze drankenkartons werden met het huishoudelijke restafval verbrand. 
Bewaarexperimenten met Nederlandse drankenkartons onder specifieke omstandigheden lieten zien dat de kwaliteit van de gerecycleerde papiervezels niet wordt beïnvloed door de bewaarduur (0-4 weken na sorteren) en temperatuur $\left(4,20,40^{\circ} \mathrm{C}\right)$. De vezels zijn goed beschermd door kunststoffolie tegen schimmelafbraak. Wel komt er een scherp ruikende geur vrij tijdens het recyclen van de drankenkartons. Deze geur is waarschijnlijk te wijten aan microbiologische afbraak van de productresten die in de kartons aanwezig zijn. Deze geur, die vrij komt bij recycling, blijft even sterk gedurende het hele experiment. Verder viel op dat ook teruggewonnen vezels, hieruit gemaakte producten en het verpulpingswater sterk ruiken. Volgens recyclingbedrijven is het met een extra inspanning mogelijk om deze geur uit de vezels, de daaruit geproduceerde producten en het proceswater te verwijderen.

De kwaliteit van gesorteerde drankenkartons uit deze studie is gedaald ten opzichte van die in de pilot 2013. De sorteerproducten in 2016-2017 bevatten meer restafval dan in 2013. Deze lagere kwaliteit heeft waarschijnlijk meerdere oorzaken: de hogere gehaltes restafval in het ingezamelde materiaal en het veranderde sorteerbeleid. Deze lagere kwaliteit van de sorteerproducten maakt de verdere verwerking hiervan lastiger. Deze grondstof ruikt sterk en is biologisch actief (met hoofdzakelijk vliegen). Van de drie recyclingbedrijven, is er één gedurende de zomer van 2017 tijdelijk gestopt met de verwerking, accepteert een ander slechts nog beperkt Nederlandse drankenkartons en heeft het derde bedrijf zijn bedrijfsvoering aangepast met directe levering en verwerking (zodat er geen opslag van materiaal op het terrein is die de buurt kan bezwaren). Vanuit het oogpunt van kwaliteit balanceert het inzamel \& recyclingsysteem voor drankenkartons op het randje van het mogelijke.

Kruisvervuiling van drankenkartons naar andere gelijktijdig ingezamelde verpakkingen treedt niet aantoonbaar op in het losse, ingezamelde materiaal. Het treedt vermoedelijk pas op nadat het materiaal wordt geperst in een pers-vrachtwagen of tijdens het balen van de sorteerproducten (met daarin kleine hoeveelheden drankenkartons). Kruisvervuiling is echter hoogstwaarschijnlijk niet de enige reden waarom de kwaliteit van alle sorteerproducten is gedaald in de afgelopen jaren. De toename van het gehalte restafval in het ingezamelde materiaal, de langere logistieke doorlooptijden en het veranderde sorteerbeleid zijn hier waarschijnlijk eveneens debet aan. 


\section{Content}

Abstract 3

Uitgebreide samenvatting $\quad 5$

$\begin{array}{lll}1 \text { Introduction } & 10\end{array}$

2 Methods 11

2.1 Sampling method and sample analysis $\quad 11$

$\begin{array}{ll}\text { 2.1.1 Studied collection and recycling chains } & 11\end{array}$

$\begin{array}{ll}\text { 2.1.2 Municipality list } & 13\end{array}$

$\begin{array}{lll}2.1 .3 & \text { Gross response data } & 13\end{array}$

$\begin{array}{ll}\text { 2.1.4 Selection of municipal samples } & 13\end{array}$

$\begin{array}{lll}2.1 .5 & \text { Sampling } & 13\end{array}$

2.1.6 Manual sorting of the samples 14

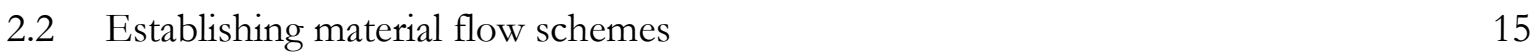

$\begin{array}{lll}2.2 .1 & \text { General data } & 15\end{array}$

2.2.2 Basic calculations within the material flow schemes prior to sorting 17

2.2.3 Calculations in material flow scheme related to the sorting process for PMD, PD and mono-P 18

2.2.4 Calculations related to the recovery recycling chain 20

2.2.5 Final parameters to express the performance of the collection and recycling $\begin{array}{ll}\text { chains } & 20\end{array}$

2.3 Quality of the paper fibres contained with Dutch beverage carton 21

2.4 Error calculations 21

2.4.1 Error analysis of the net material collection yields 22

2.4.2 Error analysis of the sorting division 22

2.4.3 Error analysis of the net material chain yield 22

2.4.4 Error analysis for the net material yield of the recovery chain 23

3 Results 24

3.1 Division of municipalities over the collection systems and potentials 24

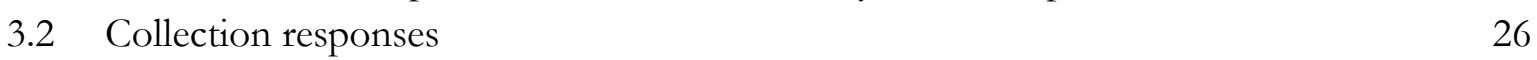

3.3 Composition 27

3.3.1 Attached moisture and dirt of the beverage cartons 30

3.3.2 Attached moisture and dirt of the co-collected materials 32

3.3.3 Presence of beverage carton look-a-likes 32

$\begin{array}{lll}\text { 3.3.4 Presence of agglomerates and their composition } & 33\end{array}$

3.3.5 Residual waste in the collected material 34

3.4 Sorting of beverage carton containing materials 36

3.4.1 Composition of sorted beverage cartons 36

3.4.2 Concentrations of beverage cartons in other sorted products 37

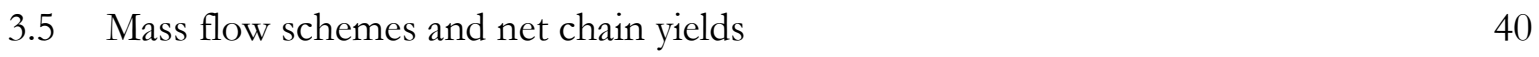


$\begin{array}{lll}3.6 & \text { Cross contamination } & 43\end{array}$

3.7 Quality decay experiment of paper fibres 44

$\begin{array}{lll}\text { 3.7.1 Pulp strength } & 45\end{array}$

$\begin{array}{lll}\text { 3.7.2 Fibre length characterisation } & 48\end{array}$

3.8 Perspective of the recycling industry 51

4 Discussion $\quad \mathbf{5 3}$

4.1 Quality of the input response data 53

4.2 Recycling system on the edge 56

5 Conclusions $\quad 57$

$\begin{array}{ll}\text { References } & 59\end{array}$

$\begin{array}{ll}\text { Acknowledgements } & 60\end{array}$

$\begin{array}{ll}\text { List of abbreviations } & 61\end{array}$

$\begin{array}{ll}\text { Appendices } & 62\end{array}$

Appendix A: All sorting results per sample $\quad 63$

Appendix B: Input Data into STAN 96

$\begin{array}{ll}\text { Appendix C: Material Flow Schemes } & 97\end{array}$

Appendix D: Paper fibre fractionation results 103

$\begin{array}{ll}\text { Appendix E: Categorisation of municipalities } & 108\end{array}$ 


\section{Introduction}

This report describes the recycling chain for beverage cartons in the Netherlands in 2016 from the households to the recycled secondary materials produced from the beverage cartons (fibres and by-products). This is a technical report, describing the yields of all the steps in the recycling chain and the quality of the (intermediate) products. The following steps in the recycling chain are discerned:

- Separate collection (both mono-collection and co-collection systems),

- Mechanical recovery of beverage cartons from MSW,

- Sorting,

- Mechanical recycling.

This study has been commanded by the three parties in the Framework treaty (Ministry I\&M, Dutch municipalities and Dutch packaging industries), via Rebel management. Our formal contact persons were Michiel Kort and Peter Blok. The study was financed by Stichting Afvalfonds Verpakkingen on behalf of the three parties. This report has been written by independent researchers of WFBR and aimed to objectively describe the post-consumer beverage carton collection and recycling chains in technical terms. This is a public report aimed at professionals stakeholders in the recycling chains and interested scientists.

Previously in 2013, a large technical pilot study has been conducted to describe the recycling chain of post-consumer beverage cartons in the Netherlands which has been documented thoroughly [Thoden van Velzen et al. 2013]. This new follow-up study is less elaborate and focuses on studying those aspects of the recycling chain that has been changed most drastically since 2013. The largest changes to the supply chain were identified to be:

- The general rise in gross responses of the co-collection systems PD and PMD,

- The rise in relevance of the PMD co-collection system,

- The simultaneous decline in relevance of the mono-collection systems for beverage cartons,

- The new Dutch recycling facility for beverage cartons van Houtum, 


\section{Methods}

\subsection{Sampling method and sample analysis}

\subsubsection{Studied collection and recycling chains}

In 2016 five different collection and recycling chains were operational for beverage cartons in the Netherlands, see Figure 1. Some municipalities operate a mono-collection scheme for beverage cartons (Mono-BC), others operate a combined co-collection system for plastic packages and beverage cartons (PD), others operate a combined co-collection system for plastic packages, metal packages and beverage cartons (PMD), others subject their municipal solid refuse waste (MSW) to mechanical recovery (Recovery). And finally some municipality do not have a collection scheme in place for beverage cartons, but only for plastic packages (Mono-P). Since in the latter scheme small amounts of beverage cartons are found, this is still a collection scheme for beverage cartons.

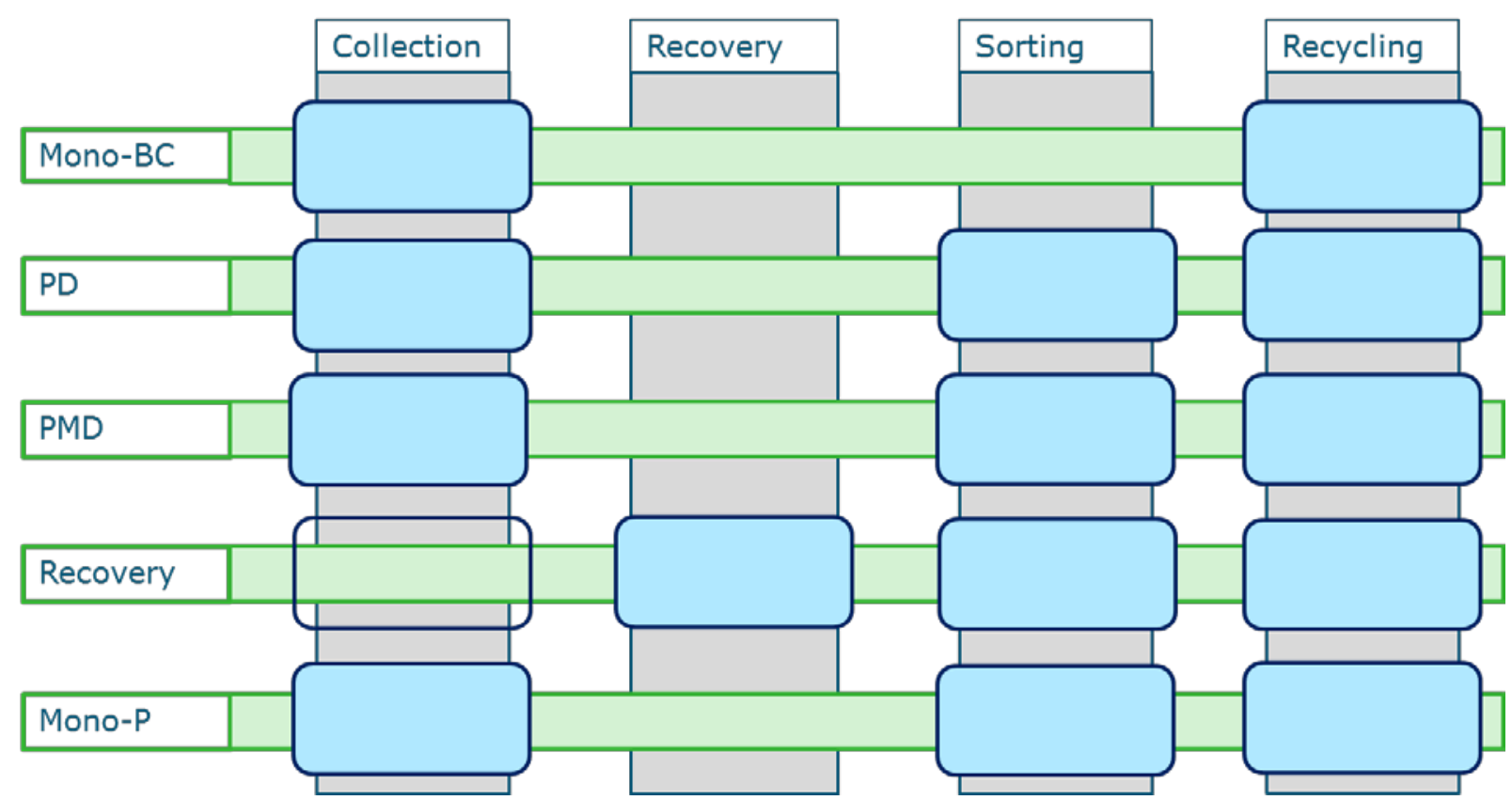

Figure 1: The five studied collection \& recycling chains for beverage cartons in the Netherlands in 2016.

\section{Separate collection of beverage cartons (Mono-BC)}

Within this mono-collection scheme civilians are expected to keep their beverage cartons separately from other waste and offer them separately for collection. Collected beverage cartons are usually cross-docked within a municipality or at a regional cross docking centre from which they are directly transported to the recycling facilities. 


\section{Co-collection with plastic packaging waste (PD)}

Combined collection with plastic packaging waste is the collection where civilians are expected to keep beverage cartons and plastic packages separate and offer them for collection in the same collection bags or mini-containers. This mixture is usually cross-docked at a regional crossdocking station and transported to a sorting facility which produce several plastic sorting products and a beverage carton sorting product. This beverage carton product is then subsequently traded with a recycling facility.

\section{Co-collection with plastic and metal packaging waste (PMD)}

Similarly to the PD collection scheme, here civilians are expected to collect beverage cartons together with plastic packages and metal packages and offer this mixture for collection. This mixture is also sorted and recycled. This collection method closely resembles the German LVP collection scheme. The abbreviation PMD was borrowed from the Belgian collection scheme of Fost-Plus. The difference with the Belgian system is, however, that in the Belgian system only plastic bottles are allowed and not all plastic packages. But recent tests in Belgium suggests that their collection portfolio might be expanded in the near future, to make the schemes more similar to the German and the Dutch schemes.

\section{Combined recovery with plastic packages from MSW (Recovery)}

In the recovery scheme civilians discard both their plastic packaging waste and beverage cartons with all other wastes in the MSW. This MSW is subsequently subjected to mechanical recovery in one of the three recovery facilities that were operational in 2016 in the Netherlands. The recovered mixture is sorted in a sorting facility and the sorting products are traded to recycling facilities.

\section{Mono-collection for plastic packages (Mono-P)}

A small amount of municipalities (29 of the $390,6.5 \%$ of the population) do not offer a collection \& recycling scheme for beverage cartons. Nevertheless, these municipalities do operate a mono-collection system for plastic packages and in the collected material a small amount of beverage cartons are found. This collected mono-P-material is sorted with the collected PD and PMD material in the same sorting facilities and hence these beverage cartons are sorted and recycled in the same manner as those in the PD and PMD chains.

All the collection \& recycling chains start with beverage cartons that are present at the Dutch households, which are being discarded. All chains end with an intermediate pulp product, a sideproduct and process waste. The pulp is used to produce either corrugated board, massive board or sanitary paper products. The side product is currently still mainly used as fuel in cement kilns, but several innovative processes have been developed, which could alter the use in the near future. 


\subsubsection{Municipality list}

The Netherlands was composed of 390 municipalities in 2016. Hedra and Rebel offered a list of all municipalities, with their main characteristics and their collection methods for packaging materials. This list was corrected by researchers of PwC and WFBR based on their personal experience, the public information which was available on the municipal websites and telephonic verification with municipal civil servants. The municipalities were categorised in the five main collection \& recycling schemes (see paragraph 2.1.1) and whether they contain more than $50 \%$ high rise buildings.

\subsubsection{Gross response data}

The gross response data was obtained from Nedvang. These are the officially registered amounts of collected packaging materials in the registration tool named Wastetool for each individual municipality in 2016. These numbers are voluntarily entered by the municipalities in Wastetool as this is not obligatory and hence this data might contain errors as a result of misconceptions of the definition of gross responses. For municipalities with a separate collection system for only beverage cartons (mono-BC) and a recovery system, the registered gross responses of beverage cartons were deemed to be the most reliable. For municipalities with a separate collection system for plastic packages (mono-P), a co-collection system for plastic packages and beverage cartons (PD) and a co-collection system for plastic packages, beverage cartons and metal packages (PMD) the gross plastic packaging responses were deemed the most reliable.

\subsubsection{Selection of municipal samples}

The budget for sampling was limited and hence 29 municipalities could be sampled with regard to collected beverage carton-containing materials (mono-BC, PD, PMD). Since the focus in the pilot of 2013 was on mono-collection and PD and the initial municipal list indicated that PMD had become the dominant collection scheme, it was decided to take 25 samples of PMD material at 25 different municipalities and 4 samples of PD material at 4 different municipalities. These 29 samples were divided over the municipalities to represent the most common collection schemes. Additionally 3 samples of sorted product from separate collection schemes (mono-P, PD and PMD) would be taken and 1 sample of a sorted product from mechanical recovery.

\subsubsection{Sampling}

Most of the sampling was done at the municipal cross-docking station for PD and PMD material. The target amount of sample was 2 bigbags, or $2 \mathrm{~m}^{3}$. Four of the targeted municipalities operated with side-feeding collection vehicles. Here the material is directly pressed in the transport container. This transport container is directly driven to the sorting facility and hence there would be no option to sample material on a cross docking station. For these type of municipalities, it 
was decided to fill two bigbags of material on the streets of the municipality in front of the collection vehicle.

Samples of sorted products were only 1 bigbag, since the concentration of beverage cartons is much higher in these materials. After sampling, and prior to manual sorting, all samples were stored in cooled cell (around $4^{\circ} \mathrm{C}$ ) to prevent moisture loss and reduce biological activity.

\subsubsection{Manual sorting of the samples}

Prior to manual sorting, the volume of the sample was estimated. This together with the total weight of the sample was used to estimate the density of the collected material.

Subsequently the sample was manually sorted and analysed in a specific order, see Figure 2. First the samples were manually sorted into nine main material categories (organic \& indefinable, paper \& board, textile, plastics, glass, metal, beverage cartons, beverage-carton-look-a-likes and agglomerates). Beverage-carton-look-a-likes are paper $\&$ board packages that resemble beverage cartons and that can be mistaken by consumers for a beverage carton, such as laminated board used to pack deep frozen products and Pringels crisps laminated board casings. Agglomerates are combinations of packages which cannot be separated into loose packages with normal force. Either they are the result of consumers' stuffing behaviour or caused by deformations of packages or by gluing action of some product residues.

After sorting the (gross) weight of all these materials was noted. Beverage cartons were then manually sorted into 14 different categories, herein listed in Table 1. After the manual sorting the gross weights of the beverage carton categories were determined. Mass percentages were calculated by taking the gross weight of a beverage carton category and dividing that by the total gross weight of the complete sample (thus including all the gross weights of residual wastes).

Two types of moisture and dirt contents were determined for all 14 types of beverage cartons per sample; the outside-attached moisture and dirt and the inside-moisture and dirt.

The outside level of moisture and dirt was determined by randomly taking 10 beverage cartons per category and sample, weighing the gross weight of the 10 cartons, cleaning the outside of the cartons with a brush and weighing the 10 cartons again (without outside dirt). These numbers were used to calculated the outside-moisture \& dirt content, see Equation 1.

Subsequently, the 10 cartons per category were cut open with scissors and washed inside and out. The opened and cleaned cartons were dried in an oven at $80^{\circ} \mathrm{C}$ overnight and in the morning their dry weights were recorded. From these numbers the inside-moisture \& dirt content was calculated, see Equation 2. Weight-averaged total (outside + inside) moisture \& dirt contents were calculated for the beverage cartons of each sample.

From the PD and PMD materials also the moisture and dirt content of 5 main type of plastic packages (PET bottle small clear, PE flasks, PP rigid others, PE film large and PET rigid others), the ferrous metals and the non-ferrous metals were determined, by randomly taking 10 packages 
per category, weighing them, washing them, drying them in the oven overnight and weighing them again.

$$
M D C_{\text {outside }},[\%]=\frac{m_{\text {gross }}^{B C \text { category }}-m_{\text {gross brushed }}^{B C \text { category }}}{m_{\text {gross }}^{B C \text { category }}}
$$

Equation 1: The moisture and dirt content of the outside of the beverage cartons category equals the difference between the gross and the gross-brushed weight divided by the gross weight.

$$
M D C_{\text {inside }},[\%]=\frac{m_{\text {gross brushed }}^{\text {BC category }}-m_{n e t}^{B C \text { category }}}{m_{\text {gross }}^{B C \text { category }}}
$$

Equation 2: The moisture and dirt content of the inside of the beverage cartons category equals the difference between the gross-brushed and the net weight divided by the gross-brushed weight.

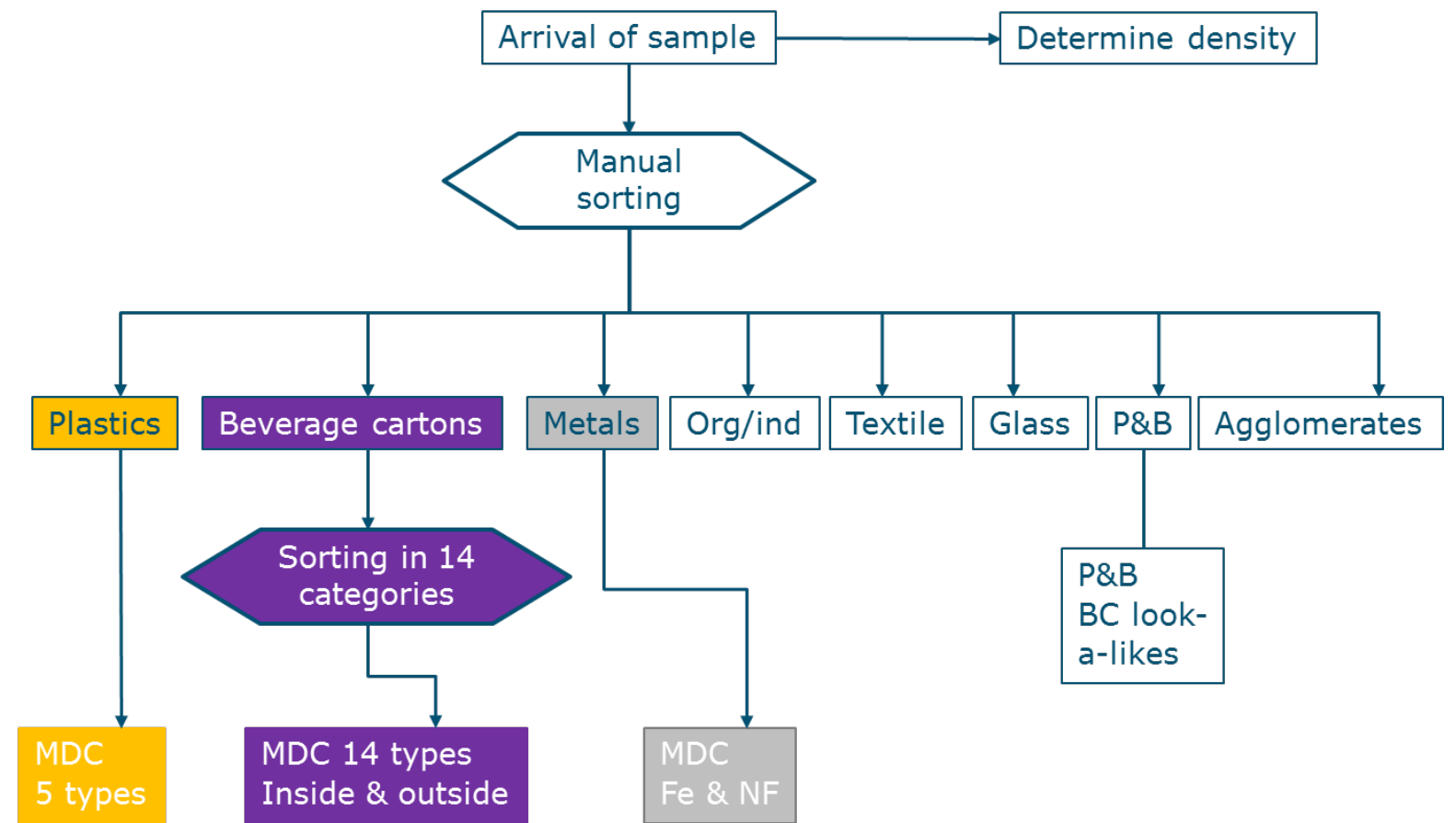

Figure 2: Work flow scheme for the analysis of the beverage carton samples.

\subsection{Establishing material flow schemes}

\subsubsection{General data}

The total amount of beverage cartons placed on the Dutch market for 2016 was approximately 58 kton net, according to Stichting Afvalfonds Verpakkingen. This number is based on the registration of packaging material use by packaging companies at the Afvalfonds. Since there always will be small amounts of beverage cartons being placed on the market by small companies that fall below the registration threshold (less than 15 tons of packaging use annually) and 
possibly also free-riders the net potential of beverage cartons was rounded to $60 \mathrm{kton}$ net for the Netherlands in 2016.

The material composition of the 14 categories of beverage cartons was assumed to be equal to the material composition that was determined in 2013 [Thoden van Velzen et al 2013], see Table 1 .

Table 1: Material composition of the most common beverage cartons per category.

\begin{tabular}{|l|c|c|c|c|c|c|}
\hline & Carton & Al & PE-foil & PE rigid & PP rigid & PP-foil \\
\hline Milk cartons $\geq 1 \mathrm{~L}$ & $79.0 \%$ & $0.0 \%$ & $13.0 \%$ & $8.0 \%$ & $0.0 \%$ & $0.0 \%$ \\
Milk cartons < 1 L & $75.0 \%$ & $0.0 \%$ & $15.0 \%$ & $10.0 \%$ & $0.0 \%$ & $0.0 \%$ \\
UHT milk cartons $\geq 1 \mathrm{~L}$ & $72.0 \%$ & $5.0 \%$ & $17.0 \%$ & $5.0 \%$ & $1.0 \%$ & $0.0 \%$ \\
UHT milk cartons < 1 L & $67.0 \%$ & $6.0 \%$ & $22.0 \%$ & $0.0 \%$ & $4.0 \%$ & $1.0 \%$ \\
Yoghurt \& dessert cartons $\geq 1 \mathrm{~L}$ & $78.0 \%$ & $0.0 \%$ & $12.0 \%$ & $10.0 \%$ & $0.0 \%$ & $0.0 \%$ \\
Yoghurt \& dessert cartons < 1 L & $79.0 \%$ & $0.0 \%$ & $16.0 \%$ & $5.0 \%$ & $0.0 \%$ & $0.0 \%$ \\
Juice cartons $\geq 1 \mathrm{~L}$ & $70.0 \%$ & $4.0 \%$ & $20.0 \%$ & $3.0 \%$ & $3.0 \%$ & $0.0 \%$ \\
Juice cartons < 1 L & $67.0 \%$ & $5.0 \%$ & $23.0 \%$ & $0.0 \%$ & $4.0 \%$ & $1.0 \%$ \\
Cartons with fresh mixes of juice \& diary $\geq 1 \mathrm{~L}$ & $78.0 \%$ & $0.0 \%$ & $13.0 \%$ & $9.0 \%$ & $0.0 \%$ & $0.0 \%$ \\
Cartons with fresh mixes of juice \& diary < 1 L & $72.0 \%$ & $0.0 \%$ & $14.0 \%$ & $14.0 \%$ & $0.0 \%$ & $0.0 \%$ \\
Cartons with UHT mixes of juice \& diary $\geq 1 \mathrm{~L}$ & $71.0 \%$ & $5.0 \%$ & $17.0 \%$ & $4.0 \%$ & $3.0 \%$ & $0.0 \%$ \\
Cartons with UHT mixes of juice \& diary $<1 \mathrm{~L}$ & $67.0 \%$ & $6.0 \%$ & $22.0 \%$ & $0.0 \%$ & $4.0 \%$ & $1.0 \%$ \\
Residual $\geq 1 \mathrm{~L}$ & $73.0 \%$ & $4.0 \%$ & $17.0 \%$ & $4.0 \%$ & $2.0 \%$ & $0.0 \%$ \\
Residual < 1 L & $67.0 \%$ & $6.0 \%$ & $22.0 \%$ & $2.0 \%$ & $3.0 \%$ & $0.0 \%$ \\
\hline
\end{tabular}

Table 2: Market division of beverage cartons and the potential of moisture and dirt in normally emptied and discarded beverage cartons.

\begin{tabular}{|c|c|c|}
\hline & Market division & Potential of MDC \\
\hline Milk cartons $\geq 1 \mathrm{~L}$ & $13.23 \%$ & $25 \%$ \\
\hline Milk cartons $<1 \mathrm{~L}$ & $0.38 \%$ & $22 \%$ \\
\hline UHT milk cartons $\geq 1 \mathrm{~L}$ & $16.24 \%$ & $30 \%$ \\
\hline UHT milk cartons $<1 \mathrm{~L}$ & $1.08 \%$ & $32 \%$ \\
\hline Yoghurt \& dessert cartons $\geq 1 \mathrm{~L}$ & $26.07 \%$ & $63 \%$ \\
\hline Yoghurt \& dessert cartons $<1 \mathrm{~L}$ & $0.95 \%$ & $64 \%$ \\
\hline Juice cartons $\geq 1 \mathrm{~L}$ & $21.22 \%$ & $28 \%$ \\
\hline Juice cartons $<1 \mathrm{~L}$ & $4.58 \%$ & $19 \%$ \\
\hline Cartons with fresh mixes of juice $\&$ diary $\geq 1 \mathrm{~L}$ & $6.59 \%$ & $52 \%$ \\
\hline Cartons with fresh mixes of juice $\&$ diary $<1 \mathrm{~L}$ & $0.54 \%$ & $48 \%$ \\
\hline Cartons with UHT mixes of juice \& diary $\geq 1 \mathrm{~L}$ & $1.69 \%$ & $35 \%$ \\
\hline Cartons with UHT mixes of juice \& diary $<1 \mathrm{~L}$ & $1.40 \%$ & $37 \%$ \\
\hline Residual $\geq 1 \mathrm{~L}$ & $1.93 \%$ & $26 \%$ \\
\hline Residual $<1 \mathrm{~L}$ & $4.10 \%$ & $53 \%$ \\
\hline
\end{tabular}


Also the market division of beverage cartons placed on the market and the potential of attached moisture and dirt for normally emptied and discarded beverage cartons were kept the same as in the pilot of 2013 [Thoden van Velzen et al. 2013], for completeness they are listed in Table 2. To recall, the potential of attached moisture and dirt is the amount of moisture and dirt that normally remains in the beverage cartons after it has been emptied and discarded in the regular manner.

\subsubsection{Basic calculations within the material flow schemes prior to sorting}

In this paragraph all intermediate parameters that are calculated within the material flow scheme prior to the sorting step are explained separately.

\section{The net potential per municipality}

The net potential per municipality is calculated as the total net potential for the Netherlands (60 kton net) times the share of the inhabitants of the Netherlands of that municipality. This implies that it is assumed that the consumption of beverage cartons is equally divided over the Dutch municipalities. This differs from the pilot 2013, when a regional correction factor was deemed necessary. Since, the data of 2016 does not suggest that such a correction factor would be required, it was not implemented. The net potential of a category of municipalities is the sum of all the net potentials of municipalities within that category.

\section{The gross potential per municipality}

The gross potential per municipality is calculated from the net potential per municipality and adding contributions for attached moisture and dirt and the other materials present in the collected material. The contributions of attached moisture and dirt is derived from the total MDC value for that municipality. The contributions of other materials are derived from the composition of the collected material. In case the municipality was not sampled itself, the average compositional data of the municipal category was taken.

$$
P o^{\text {gross }}=P o^{\text {net }} \frac{M D C}{[100 \%-M D C]}+C O M
$$

Equation 3: Gross potential is the net potential corrected for the moisture and dirt content and the contributions of other materials.

$$
\operatorname{COM}(P \& B)=P o^{n e t} \cdot \frac{c_{P \& B}}{\left[c_{B C} \cdot\left(100 \%-M D C^{p o t}\right)\right]}
$$

Equation 4: Contributions of other materials to the gross materials are calculated from the concentration of other materials in the collected material, the concentration of beverage cartons in the collected material and the potentially present moisture and dirt content. Here as an example the calculation of the additional amount of paper \& board is shown. 


\section{Net response per municipality}

The net response of beverage cartons per municipality are derived from the gross responses from which the contributions of attached moisture and dirt and co-collected other materials are subtracted, see Equation 5. Again, for municipalities which were not sampled the compositional data of the category average were used.

$$
C R^{\text {net }}=C R^{\text {gross }} \cdot c_{B C} \cdot\left[100 \%-M D C^{a v}\right]
$$

Equation 5: The net collection response of beverage cartons equals the gross collection response times the concentration of beverage cartons in the collected material and corrected for the averaged moisture and dirt content of the beverage cartons.

\section{Washed off residues}

The amount of washed off residues (WOR) by civilians in a municipality were calculated from the difference between the potentially present residues and the amount of residues calculated to be present (based on the MDC measurements of the sampled municipalities). This difference equals the amount of residues that civilians have supposedly washed off the beverage cartons prior to collection.

$$
W O R=C R^{n e t} \cdot P o^{n e t} \cdot \frac{M D C^{P o t}}{\left[100 \%-M D C^{P o t}\right]}-C R^{\text {gross }} \cdot M D C^{a v}
$$

Equation 6: The amount of washed off residues is calculated from the difference between the residues that are potentially present and the amount that was calculated to be present.

The amount of potentially present residues was calculated from the amounts that remain inside the package after normal emptying and discarding, as explained in the pilot 2013 report. In case more residues were found than what would be expected as potential, these amounts were registered as additional residues. These residues were supposed to be the consequence of discarding behaviour with more than average amounts of residues.

\subsubsection{Calculations in material flow scheme related to the sorting process for PMD, PD and mono-P}

During the pilot 2013 multiple sorting facilities were mass-balanced to derive the sorting-fates of the beverage cartons, which involves a laborious manual sorting of all products in which beverage cartons are expected. This was not an option for this study. In this study the average sorting fates of beverage cartons in the Netherlands in 2016 was derived from material flow analysis with data reconciliation techniques.

This computational method for mass balancing requires that material flows into the sorting facilities and the product flows leaving the sorting facilities are all described in terms of total masses with concomitant standard deviations and also the masses of beverage cartons entering and leaving the sorting facility are described with masses and standard deviations. The data was reconciled with STAN software [University of Vienna, Fellner 2011], which is basically a 
mathematical tool to find the best possible overall solution within the margins of the standard deviations. The output data was the reconciled data (so all the beverage carton masses and standard deviations) and a DRQ parameter which describes the quality of the reconciled data.

The total amounts of collected PMD, PD and Mono-P material were derived from gross responses of the municipalities, summed for these categories. The total amounts of beverage cartons in these three feedstock flows were derived from the total masses and the average concentration of beverage cartons in these feedstock flows. The standard deviation in the amount of beverage cartons in these feedstock equalled the product of the total amount of these feedstock flows and the standard deviation in the concentration of beverage cartons in these feedstock flows. For the concentration of beverage cartons in the mono-P feedstock the value of $0.5 \pm 0.5 \%$ was taken, which was derived from measurements in 2013 .

The total amounts of sorted products which have been registered in 2016, as being made from separately collected packaging materials, were obtained from Nedvang. The amounts of residues produced by the sorting facilities were estimated with numbers from the management of three different sorting facilities. Additionally an average moisture loss of $4.5 \%$ during the sorting process was taken into account.

The concentration of beverage cartons in the main plastic products (PET, PE, PP, Film) was estimated, by studying the photo's made of the residual material during the monthly regular quality controls of sorting facilities in 2016. The type and amount of beverage cartons were registered and based on their gross average weights in sorting products an estimation of the weight of beverage cartons in these samples was obtained. The quotients of these weights with the total sample weights gave the beverage carton concentrations in these sorting products. Because of the large numbers of quality controls and photos it was possible to obtain average values and standard deviations.

For the sorting product MIX the amount of residual material was too large and hence not all beverage cartons could be counted on the photo. Therefore, the compositional data of several sorted MIX products was used instead.

For the sorted metal products and the sorting residues, Nedvang did not have data and photo's, and hence here compositional data of these products were used.

For the concentration of beverage cartons in the sorted product "beverage cartons" the composition measured in threefold in this project was used.

The MDC of the beverage cartons in the separately collected feedstock flows is higher than the MDC of beverage cartons in sorted products, which is attributed to baling process. During the baling process the contained residues are pressed out the cartons and a part flows out of the bale in the sewage gutter of the sorting plant. To estimate the amount of pressed out residues the difference of the total MDC of the collected beverage cartons and the average level of MDC of sorted BC products $(25 \%)$ was taken. 


\subsubsection{Calculations related to the recovery recycling chain}

Municipalities with a recovery system register the amount of recovered and sorted BC product that has been produced on behalf of the municipality in Wastetool at the Beverage carton folder. These numbers are supplied to these municipalities by management of their recovery facilities. We assume that they divide the amount of sorted BC products over the municipalities in their service area based on the amount of inhabitants and the composition of the MSW. For this project the municipalities with a recovery system are treated as one entity, implying that all the contributions of single municipalities are again summed to the total amount of sorted BC. Therefore, in this project we have calculated the $\mathrm{BC}$ potentials for these municipalities and the total amount of sorted products made on their behalf. No knowledge is available from the intermediate steps: MSW collection efficiency, recovery efficiency and sorting efficiency. The MSW collection efficiency for BC's was assumed to be $100 \%$. The sorting efficiency was measured in the pilot 2013 and these numbers were rounded to 75\%. Hence from the overall chain efficiency (collection, recovery, sorting) and these assumptions, the recovery yield for BC can be estimated.

\subsubsection{Final parameters to express the performance of the collection and recycling chains}

The following parameters were used to express the overall performance of the collection and recycling schemes.

\section{The amount of products and by-products}

The amounts of recycling products formed were derived from the amount of sorted product, its composition and the transfer coefficients for the components. These transfer coefficients were derived from the measurements in the previous pilot beverage cartons in 2013. Four products were discerned: the pulp, the floating by-products, the sinking by-products and dissolved losses. Although it was originally planned to execute a mass balance of the new recycling plant Wepa Nederland BV for this project, this proved to be impossible within the time window of this project (May-August 2017) and hence the data of the previous project was used.

\section{Net chain yields}

The net chain yields were calculated as the net products of the net yields of all steps in collection and recycling chains, as depicted in Figure 1. Hence for the PMD-chain, the net chain yield, equals the product of the net collection yield, the net sorting yield and the net recycling yield. 


\subsection{Quality of the paper fibres contained with Dutch beverage carton}

The quality development of fibres contained within Dutch beverage cartons were evaluated by testing the effect of storage for prolonged time at three different temperatures $\left(4,20\right.$ and $\left.40^{\circ} \mathrm{C}\right)$. Fresh samples of beverage cartons from two different sources were taken and transported to Wageningen. Upon arrival the samples were divided into smaller samples manually and stored at the different temperatures, large plastic and metal parts were removed. After specific periods of time a sample was tested on fibre quality. The performed tests were both on pulp strength in handsheets and fibre length.

A sorted product from separate collection (named SP (P+PD+PMD)) was obtained on 23 august 2017 from sorting facility Schönmackers Kempen, that processed only Dutch separately collected material. A sorted product from the recovery system (named SP (Recovery)) was obtained from a sorted facility Augustin in Meppen on 29 August 2017, which processed only recovered material on that day.

\section{Pulp strength}

For the testing of the fibre strength in pulpsheets the stored samples were pulped in a mechanical pulper (RAS-Pulper) for 10 minutes at a consistency of $2.5 \%$. The pulp was cleaned further from smaller size impurities with a Sommerville fractionator. A slit width of $0.15 \mathrm{~mm}$ was used. Hand sheets were produced using a Rapid Köthen Sheet former. After conditioning at $23^{\circ} \mathrm{C}$ and $50 \%$ RH for more than 2 days, weight, thickness, Short Span Compressing Strength and tensile properties were determined according to ISO 536, ISO 534, ISO 1924-2 and ISO 9895.

\section{Fibre length characterisation}

For the length qualification the stored samples were pulped in in a mechanical pulper (RASPulper) for 10 minutes at a consistency of $2.5 \%$. Part of the pulped sample was fractionated using a Sommerville fractionator (slit width of $0.15 \mathrm{~mm}$ ) followed by a Bauer-McNett classifier. This resulted in five different fractions: Particles with a width $>0.15 \mathrm{~mm}$. And four different fibre length fractions: $>1.19 \mathrm{~mm},>0.595 \mathrm{~mm},>0.149 \mathrm{~mm},>0.074 \mathrm{~mm}$. All particles smaller than $0.074 \mathrm{~mm}$ in length were not determined.

\subsection{Error calculations}

The errors in the results were calculated with the error propagation laws. This is further explained in the sub-paragraphs below for the errors in the net material collection yields, sorting division and the net material chain yields. Only the error in the gross response of collected packaging materials were derived from the comparative analysis described in paragraph 4.1. 


\subsubsection{Error analysis of the net material collection yields}

The error in the calculated net collection yields varied between 0.1 and $10 \%$, see Table 6 . This error is composed of several contributions, namely the error in the gross collection response (Wastetool-data), the error in the conversion factors to calculate the net collection response and the error in the net potential.

- Error in the gross collection response. The errors in the gross collection response amount were discussed in paragraph 4.1 and the relative standard deviations varied from between $1.6 \%$ and $1.8 \%$.

- Error in the conversion factors. To convert the gross collection response in an net collection response it is multiplied with the concentration of beverage cartons in the collected material and the net material content, see equation 5 . The standard deviations in both factors was either derived as standard deviations from the averaging of multiple values from multiple samples. In case only one sample was measured, standard errors were used of $3 \%$ for the beverage carton concentration and $5 \%$ for the MDC.

- Error in the national potential of beverage cartons. The national potential of beverage cartons is according to Stichting Afvalfonds 58 ton net for 2016, but due to uncertainties in free-riders, the total was estimated to be $60 \mathrm{kton}$ as rounded figure. This implies an error of 2 kton or $3 \%$. Conservatively, we set this error to 3 kton. Furthermore, in the calculation we assumed that the consumption of beverage cartons is equally distributed over the population and that there would be no regional variation in the consumption over the country. This assumption introduces another error that cannot be estimated.

\subsubsection{Error analysis of the sorting division}

The errors in the output-data of STAN (the reconciliation software used) were used to calculate the errors in the sorting division. The sorting division is calculated by dividing the net amount of beverage cartons present in the sorting product beverage cartons divided by the net total amount of beverage cartons present in the separately collected materials. Since both net amounts are reconciled outputs from STAN and include errors, the error in the sorting division is derived from these errors.

\subsubsection{Error analysis of the net material chain yield}

The error in the calculated net material chain yields for separate collection chains are calculated to vary between $0.05 \%$ and $7 \%$, see Table 11 . This error is composed of several contributions, namely the error in the recycling yields, the error in the sorting yields, the error in collection yields. These contributions are discussed separately, below. These error-contributions have been combined with error propagation laws. For the recovery chain a separate calculation was made and hence also a different error calculation was made, see the paragraph below. 
- Error in the recycling yield. The net material recycling yields are based on measured yields during the pilot of 2013. The question is whether or not these net material recycling yields still accurately describe the recycling process of beverage cartons. On the one side, there is the opinion of personnel of the new recycling facility van Houtum that the losses of paper fibres is currently smaller. On the other hand, the quality of sorted product has declined from 2013 to 2016-2017 and hence it is likely that the losses of paper fibres has increased in comparison to 2013. Since it was not possible to measure the recycling yields in 2017, it was decided, to maintain the recycling yields of 2013 in the calculations and to estimate the error in this yield to $5 \%$.

- Error in the net amount of sorted products. The error in the net amount of sorted product is derived from the error in the gross amount of sorted product, see paragraph 2.4.2.

- Error in the net collection yield. The error in the net collection yield was calculated as described in paragraph 2.4.1.

\subsubsection{Error analysis for the net material yield of the recovery chain}

The calculation of the net material yield for the recovery chain was performed slightly different, see paragraph 2.2.4. The error in net material chain yield was calculated with the following errors in the parameters that contributed to the calculation of the yield, with the error propagation laws:

- The error in gross amount of sorted product made from recovered material was set at 10\% of the value. This relative large error in the gross amount of sorted product was chosen to reflect the uncertainty in the categorisation of the municipalities, especially regarding the municipalities that were categorised as "separate collection" but do in fact also subject their MSW to mechanical recovery.

- The error in the gross concentration of beverage cartons in the sorted product was set at $5 \%$.

- The error in the moisture and dirt content of the recovered and sorted beverage cartons was set at $5 \%$.

- The error in the fraction of the Dutch population that contributes to the recovery system was set at $1 \%$, which is relatively high in comparison to the value of $7.5 \%$ to reflect the uncertainty in the categorisation of the municipalities.

- The error in the net potential of Dutch beverage carton was set at 3 kton. The same as in the previous error calculations. 


\section{Results}

In this chapter all the results of this project are discussed per main topic: municipality list, collection, composition of beverage carton containing materials, sorting, recycling, overall chain yields, cross contamination and quality development.

\subsection{Division of municipalities over the collection systems and potentials}

The division of the municipalities over the collection systems is listed in Table 3. Since the largest collection systems are PMD and PD collection, these categories were further divided according to their collection method (drop-off or kerbside or combination of both), the presence of a Payas-you-throw (PAYT) tax system for MSW and the type of dwellings present (more or less than $50 \%$ high rise buildings), see Table 4.

Table 3: Division of the municipalities and citizen over the five collection and recycling schemes for beverage cartons in the Netherlands in 2016.

\begin{tabular}{|l|r|r|}
\hline Collection and recycling scheme & Amount of municipalities & Total amount of inhabitants \\
\hline No system for BC / Mono-P & 29 & 1096833 \\
\hline Mono BC & 7 & 224100 \\
\hline PD & 68 & 4023391 \\
\hline PMD & 247 & 10349626 \\
\hline Recovery & 39 & 1285170 \\
\hline Total & $\mathbf{3 9 0}$ & $\mathbf{1 6 9 7 9 1 2 0}$ \\
\hline
\end{tabular}

Table 4: Finer division of the collection systems for beverage cartons. HRB is an abbreviation for high-rise buildings.

\begin{tabular}{|l|l|c|c|}
\hline Name & System & $\mathbf{2 5 0} \mathbf{0 ~ H R B}$ & $<\mathbf{5 0} \% \mathbf{H R B}$ \\
\hline Mono-P (no BC) & & 2 & 27 \\
\hline Mono-BC & & 0 & 7 \\
\hline \multirow{5}{*}{ PD } & Drop-off, PAYT & 0 & 7 \\
\cline { 2 - 4 } & Drop-off, no PAYT & 4 & 11 \\
\cline { 2 - 4 } & Kerbside, PAYT & 0 & 33 \\
\cline { 2 - 4 } & Kerbside, no PAYT & 0 & 10 \\
\cline { 2 - 4 } & Comb., PAYT & 0 & 0 \\
\cline { 2 - 4 } & Comb, no PAYT & 0 & 3 \\
\hline \multirow{5}{*}{ PMD } & Drop-off, PAYT & 0 & 22 \\
\cline { 2 - 4 } & Drop-off, no PAYT & 3 & 95 \\
\cline { 2 - 4 } & Kerbside, PAYT & 0 & 82 \\
\cline { 2 - 4 } & Kerbside, no PAYT & 6 & 8 \\
\cline { 2 - 4 } & Comb., PAYT & 0 & 23 \\
\cline { 2 - 4 } & Comb, no PAYT & 1 & 37 \\
\hline \multirow{5}{*}{ Recovery } & & 2 & 7 \\
\hline
\end{tabular}


Based on this division of municipalities over the collection scheme and the intention to sample more PMD than PD municipalities, the total amount of samples from collected material was divided; 25 of PMD and 4 of PD. This division is shown in Table 5. Within each category first municipalities were chosen, that were also targeted by $\mathrm{PwC}$ for the economic analysis, in order to maximise the overlap between the two studies.

Table 5: The amount of inhabitants, the net potential of beverage cartons and the gross potential of the collection portfolio per collection system.

\begin{tabular}{|l|r|r|r|r|}
\hline System & $\begin{array}{r}\text { Amount of } \\
\text { inhabitants }\end{array}$ & $\begin{array}{r}\text { Amount of } \\
\text { samples }\end{array}$ & $\begin{array}{r}\text { Net potential } \\
{[\mathrm{kg} \text { net }}\end{array}$ & $\begin{array}{r}\text { Gross potential } \\
\text { [kg gross }]\end{array}$ \\
\hline No BC / Mono-P & 1096833 & 0 & $3,875,936$ & $24,750,826$ \\
\hline Mono BC & 224,100 & 0 & 791,914 & $1,548,456$ \\
\hline Recovery & $1,285,170$ & 0 & $4,541,472$ & $43,192,733$ \\
\hline PD DO NP $<50 \%$ & 625,121 & 1 & $2,209,023$ & $32,821,053$ \\
\hline PD DO NP $\geq 50 \%$ & $1,567,178$ & 1 & $5,538,018$ & $47,623,760$ \\
\hline PD DO PA $<50 \%$ & 362,875 & 0 & $1,282,310$ & $11,679,526$ \\
\hline PD KS NP $<50 \%$ & 253,355 & 1 & 895,294 & $7,240,712$ \\
\hline PD KS PA $<50 \%$ & 940,432 & 1 & $3,323,254$ & $28,487,134$ \\
\hline PD CO NP $<50 \%$ & 274,430 & 0 & 969,768 & $8,832,828$ \\
\hline PD Total & $4,023,391$ & 4 & $14,217,666$ & $136,685,012$ \\
\hline PMD DO NP $<50 \%$ & $1,219,283$ & 2 & $4,308,644$ & $55,508,614$ \\
\hline PMD DO NP $\geq 50 \%$ & 601,608 & 1 & $2,125,933$ & $29,675,609$ \\
\hline- PMD DO PA $<50 \%$ & 289,670 & 3 & $1,023,622$ & $11,663,979$ \\
\hline PMD KS NP $<50 \%$ & $3,143,570$ & 5 & $11,108,597$ & $115,392,658$ \\
\hline PMD KS NP $\geq 50 \%$ & 707,149 & 3 & $2,498,889$ & $26,771,901$ \\
\hline PMD KS PA $<50 \%$ & $2,609,574$ & 6 & $9,221,587$ & $102,917,793$ \\
\hline PMD CO NP $<50 \%$ & $1,292,094$ & 2 & $4,565,940$ & $48,190,153$ \\
\hline PMD CO NP $\geq 50 \%$ & 18,572 & 1 & 65,629 & 656,960 \\
\hline PMD CO PA $<50 \%$ & 468,106 & 2 & $1,654,171$ & $16,541,731$ \\
\hline PMD total & $10,349,626$ & 25 & $36,573,012$ & $407,319,398$ \\
\hline Grand Total & $\mathbf{1 6 , 9 7 9 , 1 2 0}$ & $\mathbf{2 9}$ & $\mathbf{6 0 , 0 0 0 , 0 0 0}$ & $\mathbf{6 1 3 , 4 9 6 , 4 2 4}$ \\
\hline
\end{tabular}

The net potential of dry and clean beverage cartons is calculated based on the division of the amount of inhabitants per collection system, see Table 5. The gross potentials were calculated based on the net potentials and the average composition of the collected materials, these are also listed in Table 5. 


\subsection{Collection responses}

The total gross responses per category as derived from Wastetool are listed in Table 6. From these numbers the net beverage carton response and yields are calculated. The calculation of the error in the net collection yield, is explained in paragraph 2.4.1.

Table 6: Gross total response per category of the collection systems, the net BC response and the derived net collection yields. Recovery is not shown, since the calculation is performed differently.

\begin{tabular}{|c|c|c|c|}
\hline System & $\begin{array}{l}\text { Gross total } \\
\text { response, } \\
{[\text { ton gross } / \mathrm{a}]}\end{array}$ & $\begin{array}{c}\text { Net } \mathrm{BC} \text { response } \\
{[\text { ton net/a] }}\end{array}$ & $\begin{array}{c}\text { Net collection yield, } \\
{[\%]}\end{array}$ \\
\hline No BC / Mono-P & 8,108 & $28 \pm 6$ & $0.7 \pm 0.1 \%$ \\
\hline Mono BC & 423 & $225 \pm 22$ & $28 \pm 2 \%$ \\
\hline PD DO NP $<50 \%$ & 6,261 & $250 \pm 130$ & $11 \pm 6 \%$ \\
\hline PD DO NP $\geq 50 \%$ & 4,361 & $310 \pm 82$ & $6 \pm 2 \%$ \\
\hline $\mathrm{PD} D O \mathrm{PA}<50 \%$ & 5,090 & $500 \pm 200$ & $39 \pm 16 \%$ \\
\hline PD KS NP $<50 \%$ & 2,752 & $380 \pm 60$ & $43 \pm 3 \%$ \\
\hline PD KS PA $<50 \%$ & 19,846 & $2,500 \pm 400$ & $75 \pm 13 \%$ \\
\hline PD CO NP $<50 \%$ & 4,785 & $470 \pm 180$ & $48 \pm 20 \%$ \\
\hline PD Total & 43,094 & $4,400 \pm 1,100$ & $31 \pm 4 \%$ \\
\hline PMD DO NP $<50 \%$ & 14,472 & $820 \pm 290$ & $19.0 \pm 0.6 \%$ \\
\hline PMD DO NP $\geq 50 \%$ & 1,706 & $106 \pm 22$ & $5.0 \pm 0.4 \%$ \\
\hline $\mathrm{PMD}$ DO $\mathrm{PA}<50 \%$ & 8,086 & $580 \pm 90$ & $57 \pm 4 \%$ \\
\hline PMD KS NP $<50 \%$ & 43,848 & $3,700 \pm 1,500$ & $33 \pm 3 \%$ \\
\hline $\mathrm{PMD} K \mathrm{KS} N \mathrm{NP} \geq 50 \%$ & 4,388 & $480 \pm 190$ & $19 \pm 2 \%$ \\
\hline PMD KS PA < $50 \%$ & 65,697 & $5,700 \pm 1,300$ & $62 \pm 5 \%$ \\
\hline $\mathrm{PMD} C \mathrm{CO} \mathrm{NP}<50 \%$ & 24,227 & $1,900 \pm 700$ & $42 \pm 8 \%$ \\
\hline PMD CO NP $\geq 50 \%$ & 278 & $40 \pm 5$ & $61 \pm 4 \%$ \\
\hline $\mathrm{PMD} \mathrm{CO} \mathrm{PA}<50 \%$ & 12,944 & $1,200 \pm 190$ & $73 \pm 10 \%$ \\
\hline PMD total & 175,647 & $14,600 \pm 4,000$ & $40 \pm 6 \%$ \\
\hline
\end{tabular}

The net collection yields roughly show the same trend between the collection systems.

The factors contributing to a higher net collection yield are in general:

- Co-collection systems: PMD > PD > Mono-BC,

- PAYT > Non-PAYT municipalities,

- Municipalities with $<50 \%$ high-rise buildings $>$ those with $\geq 50 \%$ high-rise buildings,

- Combined kerbside + drop-off $>$ kerbside only. 
Table 6 makes it very clear that the collected materials contain only small net amounts of beverage cartons, which relates to both the low gross concentration of beverage cartons and the high MDC of the beverage cartons.

\subsection{Composition}

The analysis results of the 29 samples of collected material are anonymously listed in Appendix A. The main compositional parameters are listed in Table 7 per category of collection system. When multiple samples were taken from the same category, the average values are presented. For categories which were not studied during this project (mono-BC and no-BC), the values of the previous projects are displayed [Thoden van Velzen et al. 2013]. For the two PD categories which were not sampled the average of the other 4 categories and of the previous pilot is used and displayed.

Table 7: Gross main composition of the collected materials [\% gross weight/gross weight]. Averages are shown in case multiple samples were taken for that category. Blue values indicate that no samples were available for that category and average (blue) values were used.

\begin{tabular}{|c|c|c|c|c|}
\hline Collection system & $\begin{array}{c}\text { Beverage } \\
\text { cartons }\end{array}$ & Plastics & Metals & $\begin{array}{l}\text { Residual } \\
\text { wastes }\end{array}$ \\
\hline No BC / Mono-P & 0.5 & 89.9 & 1.8 & 7.8 \\
\hline Mono BC & 78.6 & 4.1 & 0.6 & 16.7 \\
\hline PD DO NP $<50 \%$ & 6.1 & 56.6 & 11.8 & 25.5 \\
\hline$P D D O N P \geq 50 \%$ & 12.7 & 83.8 & 0.3 & 3.3 \\
\hline PD DO PA $<50 \%$ & 15.5 & 71.9 & 2.9 & 9.7 \\
\hline $\mathrm{PD} K S \mathrm{NP}<50 \%$ & 22.7 & 76.6 & 0.2 & 0.5 \\
\hline $\mathrm{PD} K \mathrm{KS} \mathrm{PA}<50 \%$ & 20.3 & 73.1 & 0.8 & 5.8 \\
\hline$P D C O N P<50 \%$ & 15.5 & 71.9 & 2.9 & 9.7 \\
\hline PD Total & $16 \pm 7$ & $72 \pm 10$ & $3 \pm 5$ & $10 \pm 2$ \\
\hline PMD DO NP $<50 \%$ & $9 \pm 3$ & $67 \pm 3$ & $6.4 \pm 1.4$ & $18 \pm 2$ \\
\hline PMD DO NP $\geq 50 \%$ & 10.5 & 50.5 & 8.3 & 30.7 \\
\hline PMD DO PA $<50 \%$ & $10.2 \pm 1.4$ & $67 \pm 10$ & $8 \pm 2$ & $14 \pm 11$ \\
\hline PMD KS NP $<50 \%$ & $12 \pm 5$ & $74 \pm 10$ & $7 \pm 3$ & $8 \pm 6$ \\
\hline PMD KS NP $\geq 50 \%$ & $16 \pm 6$ & $60 \pm 17$ & $8.8 \pm 1.5$ & $16 \pm 14$ \\
\hline PMD KS PA $<50 \%$ & $14 \pm 3$ & $63 \pm 4$ & $9 \pm 2$ & $14.3 \pm 1.8$ \\
\hline $\mathrm{PMD} C \mathrm{CO} \mathrm{NP}<50 \%$ & $13 \pm 4$ & $70 \pm 3$ & $8.4 \pm 0.6$ & $8.5 \pm 1.3$ \\
\hline PMD CO NP $\geq 50 \%$ & 20.0 & 59.4 & 11.3 & 9.3 \\
\hline PMD CO PA $<50 \%$ & $14.7 \pm 0.3$ & $71 \pm 2$ & $8.7 \pm 1.2$ & $6.0 \pm 1.4$ \\
\hline PMD total & $13 \pm 4$ & $66 \pm 9$ & $8 \pm 2$ & $13 \pm 8$ \\
\hline
\end{tabular}


These main compositional figures show a large variation, especially in the percentage of residual waste and plastics. But also in the gross percentage of beverage cartons in the Dutch PMD material the variation is substantial; on average $13 \pm 4 \%$. This substantial variation is also eminent from Figure 3.

\section{Composition PD municipalities}

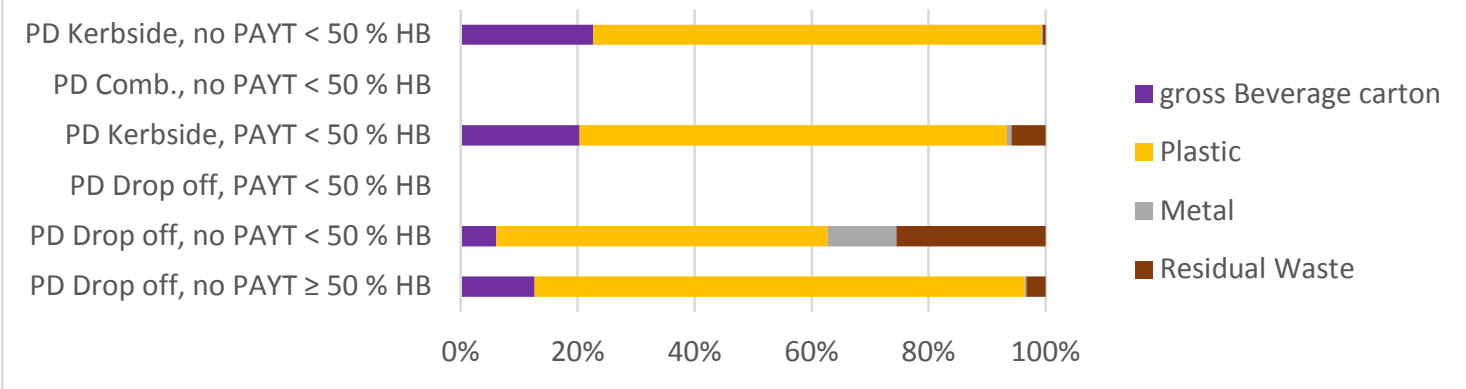

\section{Composition PMD municipalities}

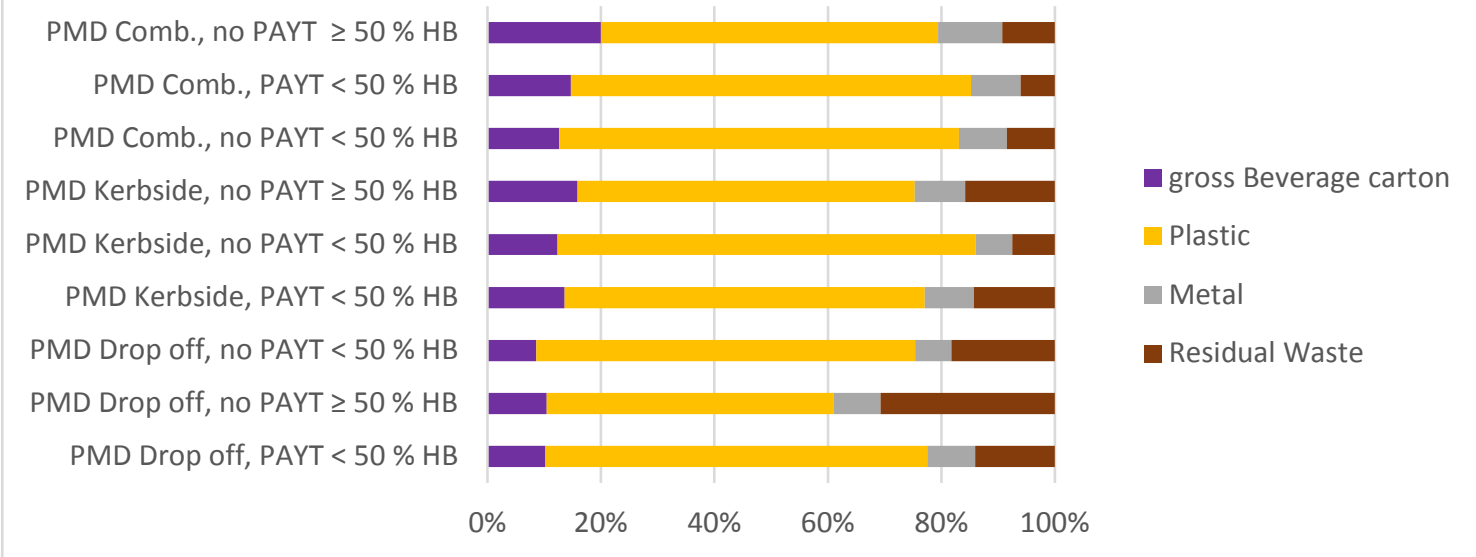

Figute 3: Gross composition of the analysed PD (above) and PMD (below) material.

The composition of the beverage cartons with regard to the 14 types of beverage cartons was also studied for each sample, see Appendix A. This beverage carton composition is averaged for the PD and PMD samples and graphically compared to the average data of the pilot in 2013 for beverage cartons from the Mono-BC and the PD system. As can be seen in Figure 4 the beverage carton composition has hardly changed between 2013 and 2016. Perhaps a small shift has occurred in market share between juice and yoghurt cartons. This is further substantiated by a comparison of the market division in 2013 (which was derived from the composition of all beverage cartons found during a mass balancing of a mechanically recovered facility in 2013) and the estimated market division in 2016, derived from the average composition of beverage cartons in the PD and PMD samples, as is listed in Table 8. 


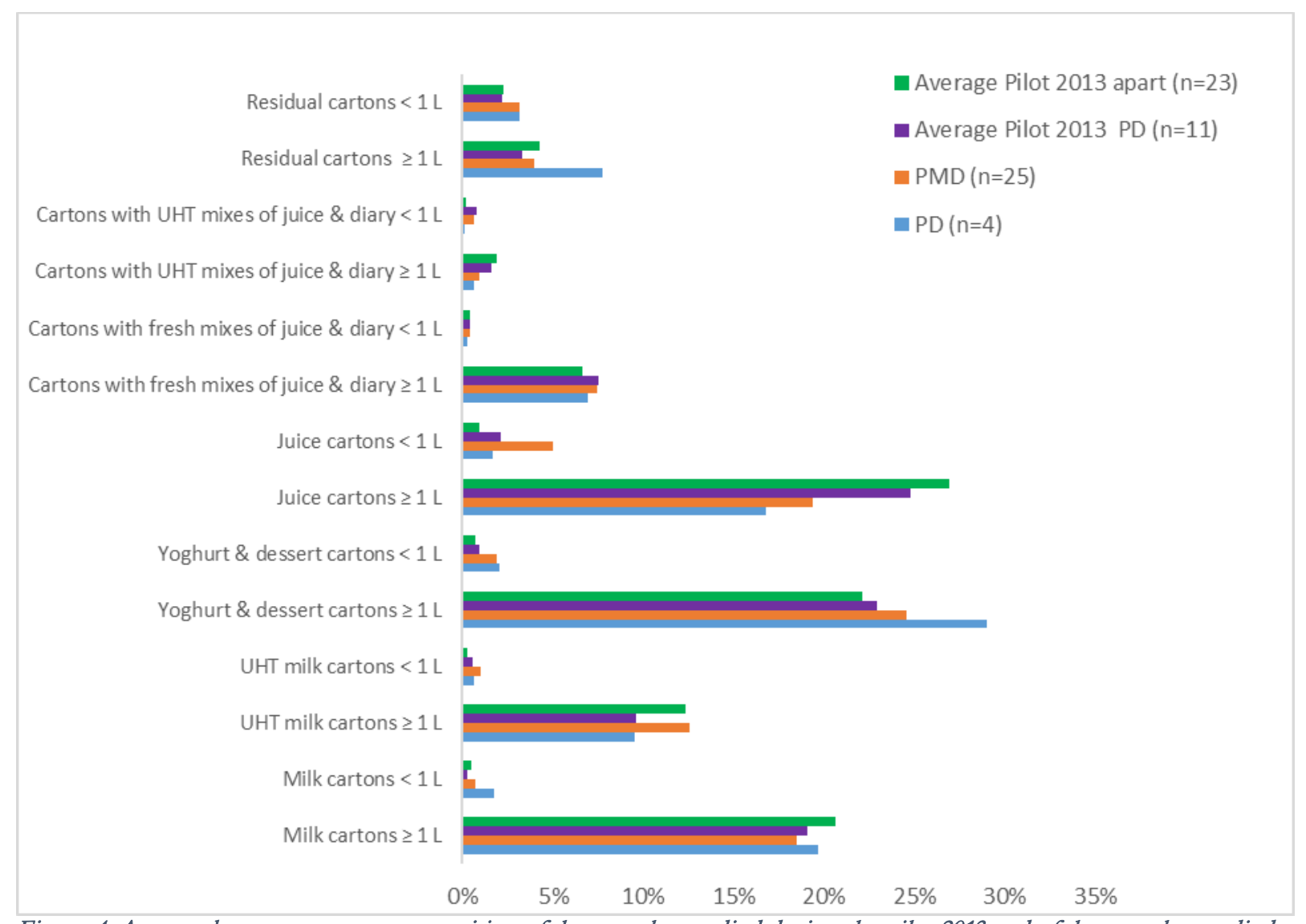

Figure 4: Average beverage carton composition of the samples studied during the pilot 2013 and of the samples studied for the evaluation 2016/2017, [\% gross weight / gross weight].

Table 8: Market division of beverage cartons in 2013 compared with the estimated division in 2016-2017.

\begin{tabular}{|l|c|c|}
\hline & & $\begin{array}{c}\text { Estimated market } \\
\text { division in 2016 }\end{array}$ \\
\hline Milk cartons $\geq 1 \mathrm{~L}$ & Market division 2013 & $19 \pm 7 \%$ \\
Milk cartons < 1 L & $13.23 \%$ & $0.8 \pm 1.3 \%$ \\
UHT milk cartons $\geq 1 \mathrm{~L}$ & $0.38 \%$ & $12 \pm 9 \%$ \\
UHT milk cartons $<1 \mathrm{~L}$ & $16.24 \%$ & $1.0 \pm 1.6 \%$ \\
Yoghurt \& dessert cartons $\geq 1 \mathrm{~L}$ & $1.08 \%$ & $25 \pm 10 \%$ \\
Yoghurt \& dessert cartons $<1 \mathrm{~L}$ & $26.07 \%$ & $2 \pm 2 \%$ \\
Juice cartons $\geq 1 \mathrm{~L}$ & $0.95 \%$ & $20 \pm 7$ \\
Juice cartons $<1 \mathrm{~L}$ & $21.22 \%$ & $5 \pm 12 \%$ \\
Cartons with fresh mixes of juice \& diary $\geq 1 \mathrm{~L}$ & $4.58 \%$ & $6 \pm 4 \%$ \\
Cartons with fresh mixes of juice \& diary <1 L & $6.59 \%$ & $0.5 \pm 0.7 \%$ \\
Cartons with UHT mixes of juice \& diary $\geq 1 \mathrm{~L}$ & $0.54 \%$ & $0.9 \pm 1.1 \%$ \\
Cartons with UHT mixes of juice \& diary $<1 \mathrm{~L}$ & $1.69 \%$ & $0.5 \pm 1.0 \%$ \\
Residual $\geq 1 \mathrm{~L}$ & $1.40 \%$ & $5 \pm 6 \%$ \\
Residual $<1 \mathrm{~L}$ & $1.93 \%$ & $3.2 \pm 1.7 \%$ \\
\hline
\end{tabular}


A general note of the sampling process and the participation of the municipalities should be made. In general, it was more difficult to obtain samples from municipalities in 2017 than in 2013. Although there were still several enthusiastic contributing municipalities, we were now also confronted with roughly 5 municipalities that refused to co-operate and which caused us to adjust the sampling plan a few times.

\subsubsection{Attached moisture and dirt of the beverage cartons}

The moisture and dirt contents, both on the outside of the carton and the inside of the carton, were measured for each type of beverage carton in each sample. The outside- and inside-MDC levels were weight-averaged for each sample, also total weight-averaged MDC levels were calculated.

In Figure 5 the averaged levels of MDC on the outside of the cartons and the inside of the cartons are shown for the different collection systems. The product residues within the carton are much more substantial than those on the exterior of the cartons.

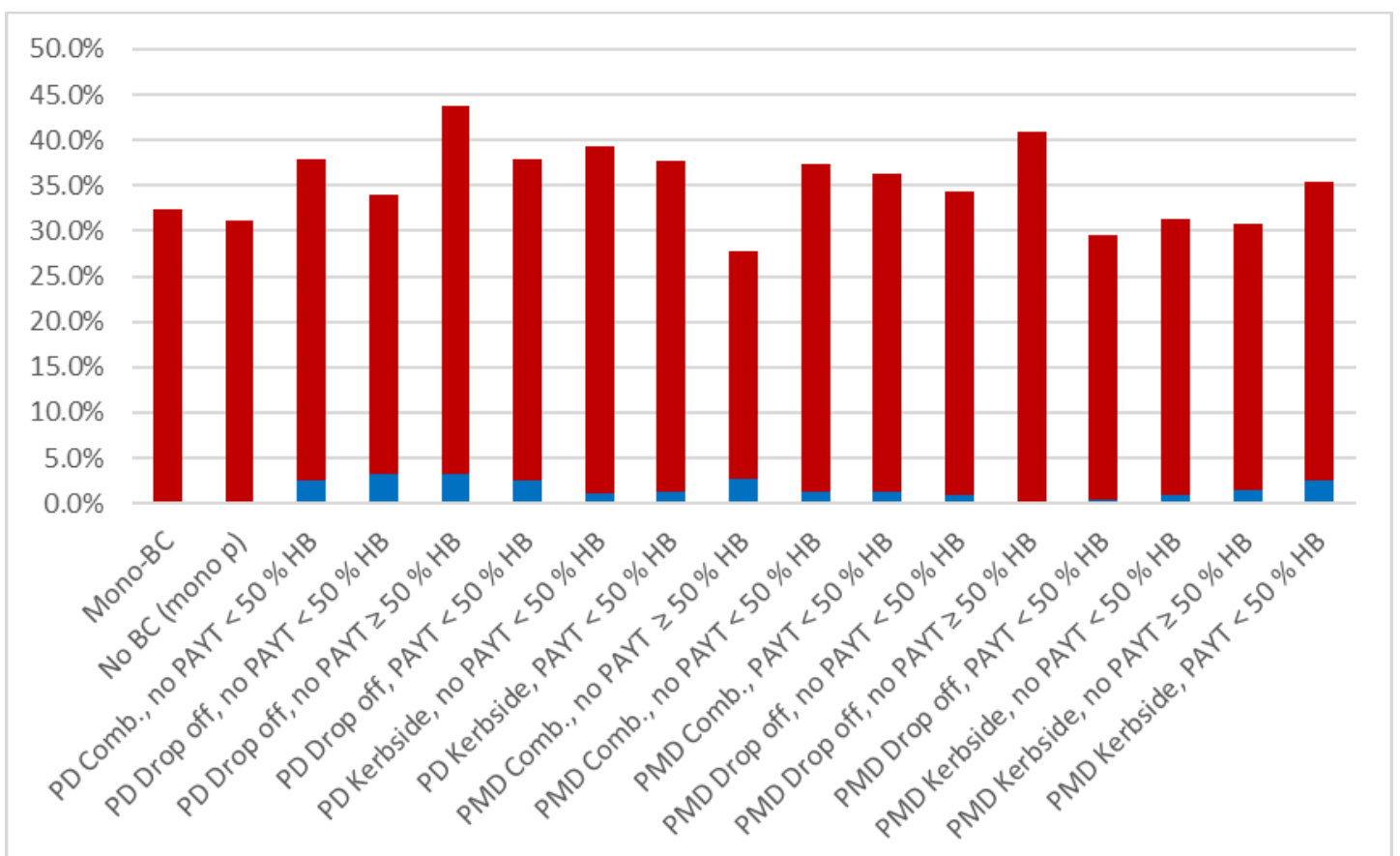

Figure 5: The averaged levels of moisture and dirt on the outside and the inside of the cartons for the different collection systems. The results of the first two systems (Mono-BC and No BC) were taken from previous project in which no distinction was made between $M D C$ in- and outside the carton.

No clear relationship is seen between the collection system and the total averaged MDC levels. Nevertheless, it is noticed that the two highest total averaged MDC levels are registered for municipalities with more than $50 \%$ high rise buildings and a drop-off collection system. Since, most of these municipalities operate a drop-off system, these factors are related. Too few samples of these municipalities were analysed to definitely prove or refute this correlation, but it is still the 
only trend in the data that can be observed. Other aspects of the collection system clearly do not correlate with the total average MDC level, such as: portfolio (mono, PD, PMD), PAYT (yes, no) and method (drop-off, kerbside).

The total levels of MDC is unevenly distributed over the types of beverage cartons. This is shown in Figure 6 in a comparative manner between the beverage cartons studied in the pilot of 2013 and those studied in the evaluation study of 2016-2017.

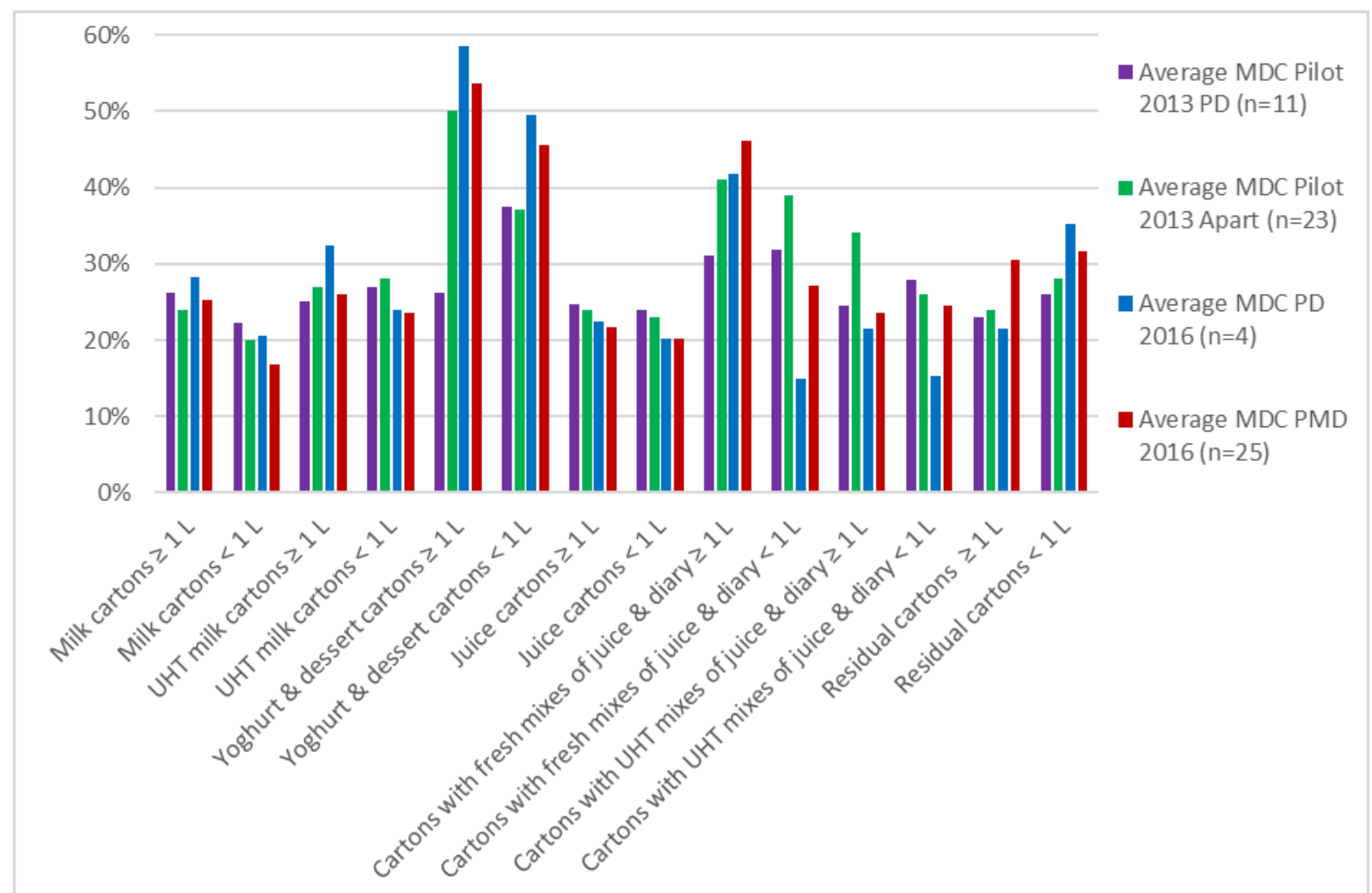

Figure 6: A comparison of the total a veraged levels of $M D C$ for the 14 types of beverage cartons between those from pilot in 2013 and the evaluation study in 2016-2017.

The highest levels of total MDC (40-60\%) are recorded for cartons which contain: yoghurt, desserts and mixes of juice and diary. These levels were high in the past and are still high. In contrast the total MDC levels for milk and juice cartons are relatively low (20-30\%). These levels were low and are still low, so we found no evidence to support markedly changed MDC levels in Dutch beverage cartons. Hence, although consumer campaigns have been held to promote consumers to empty, rinse and flatten the cartons, we see no effect of these campaigns in these measured MDC levels. 


\subsubsection{Attached moisture and dirt of the co-collected materials}

The MDC-levels were also measured for 5 main types of plastic packages and 2 types of metal packaging. These MDC-values for the 5 plastic packaging types are weight-averaged to an overall MDC level for plastic packages and compared to previously measured values.

This observed level of variation is substantial, which could not easily be related to collection methods or types of municipalities, so we suppose that the cause of this variation is mostly due to regular sample-to-sample variation.

Table 9: Averaged total MDC levels for non-beverage carton packages in various collection systems.

\begin{tabular}{|l|l|l|l|}
\hline MDC & Mono-P 2010-2013 & PD 2016-2017 & PMD 2016-2017 \\
\hline Plastic packages & $14 \pm 7 \%$ & $12 \pm 5 \%$ & $10 \pm 3 \%$ \\
\hline $\begin{array}{l}\text { Ferrous metal } \\
\text { packages }\end{array}$ & & $5 \pm 3 \%$ \\
\hline $\begin{array}{l}\text { Non-ferrous metal } \\
\text { packages }\end{array}$ & & $8 \pm 3 \%$ \\
\hline
\end{tabular}

\subsubsection{Presence of beverage carton look-a-likes}

Since there are a few packages that are composed of both board and plastic, they might be mistaken by consumers for a beverage carton and be also present in the collected material. Hence, we also created a separate category for 'beverage carton look-a-likes' while sorting the materials. However, hardly any packages could be registered as a look-a-like. Only a few laminated board packages for deep-frozen vegetables, ice cream cartons, crisp canisters and fast food packages were found, see the photos in Figure 7. The average concentration of look-a-likes in collected PD and PMD was $0.3 \pm 0.3 \%$. The highest recorded concentration was $1 \%$. No clear difference between PD and PMD municipalities was observed. Hence the presence of looka-likes in the collected materials does not pose any problem or risk for the sorting and recycling industries, other contaminants, such as organic waste, textiles are in comparison much more problematic.

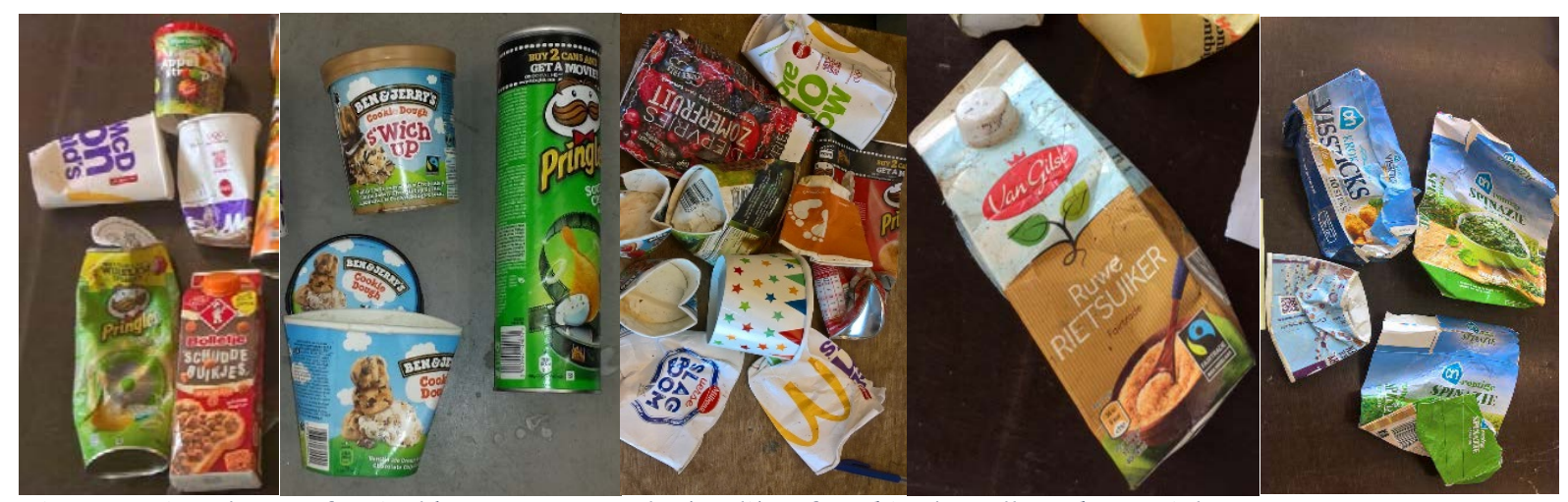

Figure 7: Five photos of typical beverage carton look-a-likes found in the collected materials. 


\subsubsection{Presence of agglomerates and their composition}

Agglomerates were found in roughly half of the studied PD (2 of 4) and PMD (13 of 25) samples. When agglomerates were present, $17 \pm 14$ of them were found, representing $1.5 \pm 1.6 \%$ gross weight of the sample. The material composition of agglomerates reveals that metals $(51 \pm$ $24 \%)$ and plastics $(39 \pm 22 \%)$ are mostly present in agglomerates. Whereas beverage cartons $(6 \pm$ $8 \%)$, paper \& board $(3 \pm 3 \%)$, organics $(1.4 \pm 3 \%)$ and textiles $(0.03 \pm 0.09 \%)$ are in much fewer occasions part of an agglomerate. Glass was not found in an agglomerate.

In Figure 8 four random photos of agglomerates are shown.

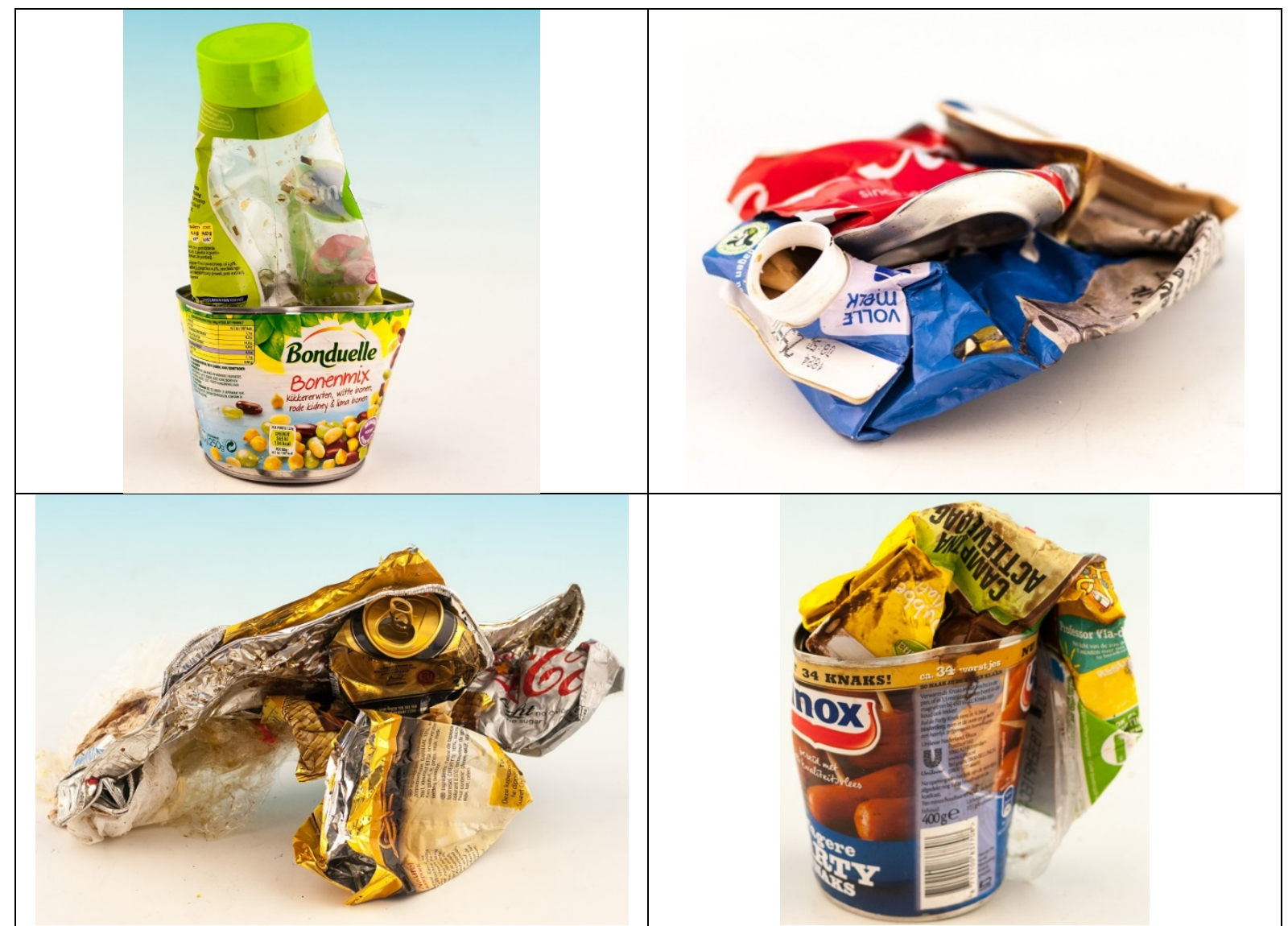

Figure 8: Four photos of random agglomerates found in PMD material.

Many agglomerates were clearly the result of stuffing behaviour of consumers, other appeared to originate from mechanical deformations (flattening). 


\subsubsection{Residual waste in the collected material}

The percentage of residual waste in the separately collected PMD material varies strongly between municipalities, as is already apparent from Figure 3. This has been depicted in more detail in the boxplots in Figure 9. Here the percentage of residual waste is shown in Mono-P material collected and studied between 2010-2013 and PMD material collected and studied in this project (2016-2017). The definition of residual waste has shifted in time. For the Mono-P collection systems this was all the other materials that were not plastic, hence including metals and beverage cartons. Whereas for the PMD systems the definition of residual excluded those two materials.

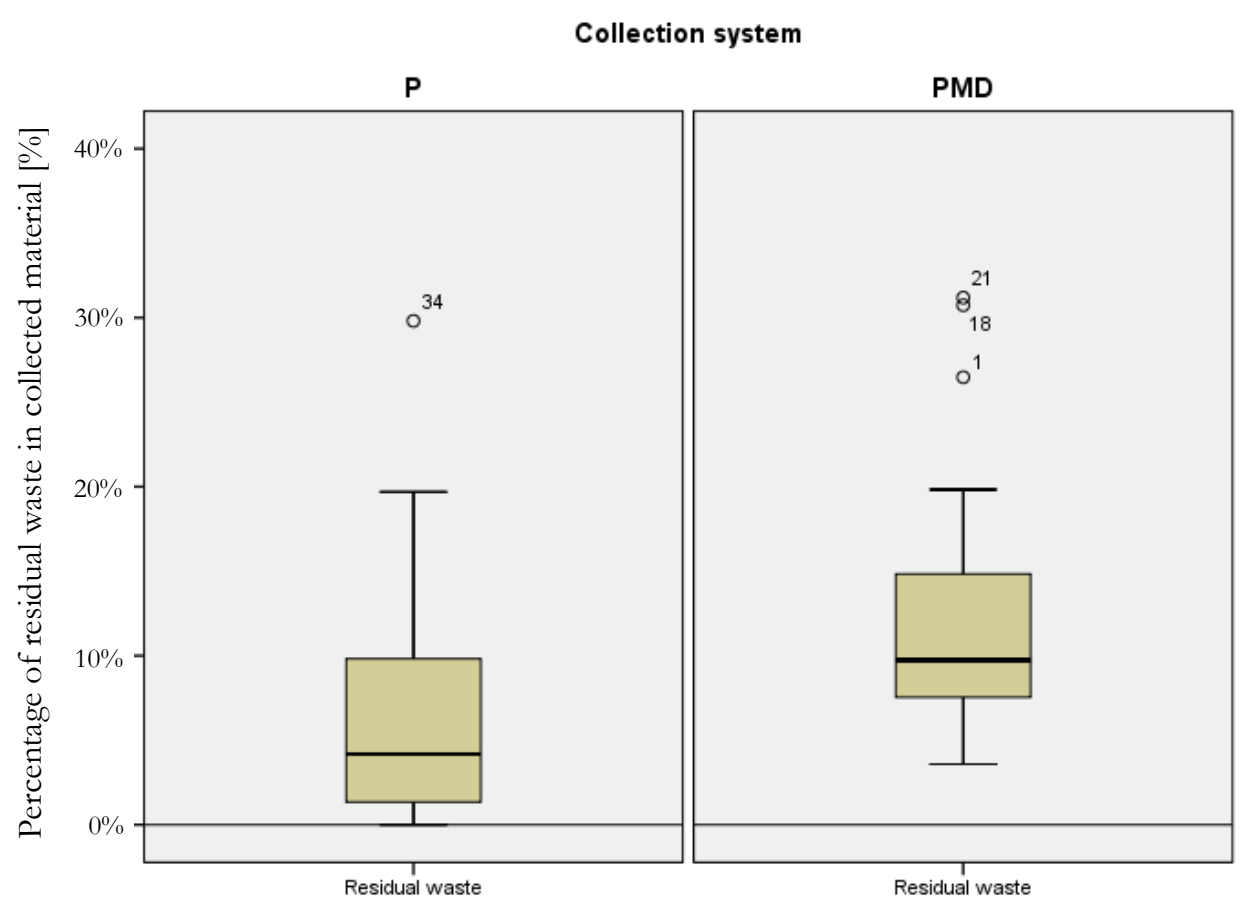

Figure 9: Boxplot of the percentage of residual waste in collected mono-P-material from 2010-2013 ( $n=15,7 \pm 9 \%$ ) and PMD material from 2016-2017 ( $n=24,13 \pm 8 \%)$.

The average amounts of residual wastes are for both data sets $7 \pm 9 \%$ and $13 \pm 8 \%$ and hence overlapping. Remarkably the amount of outliers are larger for the PMD-dataset than for the Mono-P dataset. The single-sided t-test proves that the PMD-material contains on average significantly more residual waste than the Mono-P-material (0.029). This boxplot confirms opinions of collection operators in rural parts of the Netherlands that their currently collected PMD material is similarly polluted than their Mono-P-material was prior to 2014. But it also confirms opinions of sorting companies that a growing number of collection areas and municipalities collect PMD material that is strongly polluted with more than $10 \%$ of residual waste and cannot be accepted. The three outliers in the PMD dataset all have a drop-off collection system, which apparently poses a larger risk for contamination. However, not all 
studied drop-off systems produce such outliers. Furthermore, according to representatives of sorting facilities the source of residual wastes in PMD is not limited to drop-off systems and also areas with a kerbside collection system with mini-containers have to be rejected repetitively. These results reveal similar trends as the LCKVA report on the composition of the PMD material, although the definitions of plastics and impurities are slightly different in this study [Leenaars 2017]. In the latter study, the most impurities (also residual waste) were found in PMD collected in municipalities with a drop-off system and mini-containers, with PAYT system and with reversed collection [Leenaars 2017].

The widening of the collection portfolio (from mono-P to PMD) has apparently attracted residual waste to the collected packaging material. Although other factors that occurred simultaneously like the introduction of the Dutch VANG-policy and local translation into policies to discourage civilians to produce MSW might also have contributed to the rise of residual waste in the collected material. In some municipalities this hardly caused much more foreign material, in most municipalities this exceeded $10 \%$ and in some exceptional cases it even approached $30 \%$.

The residual waste present in PMD material (in average 12.7\%) is composed of: $5.9 \%$ organic and indefinable materials, $4.0 \%$ paper \& board, $1.3 \%$ textiles and $0.8 \%$ glass. 


\subsection{Sorting of beverage carton containing materials}

\subsubsection{Composition of sorted beverage cartons}

The composition of three sorted products 'beverage cartons' made from separately collected materials (mono-P, PD and PMD) and originating from three different sorting facilities is listed in Appendix A. Also one sorted beverage carton product originating from mechanical recovery is listed in the same appendix. A graphical representation of the material composition of the four sorted products is given in Figure 10.

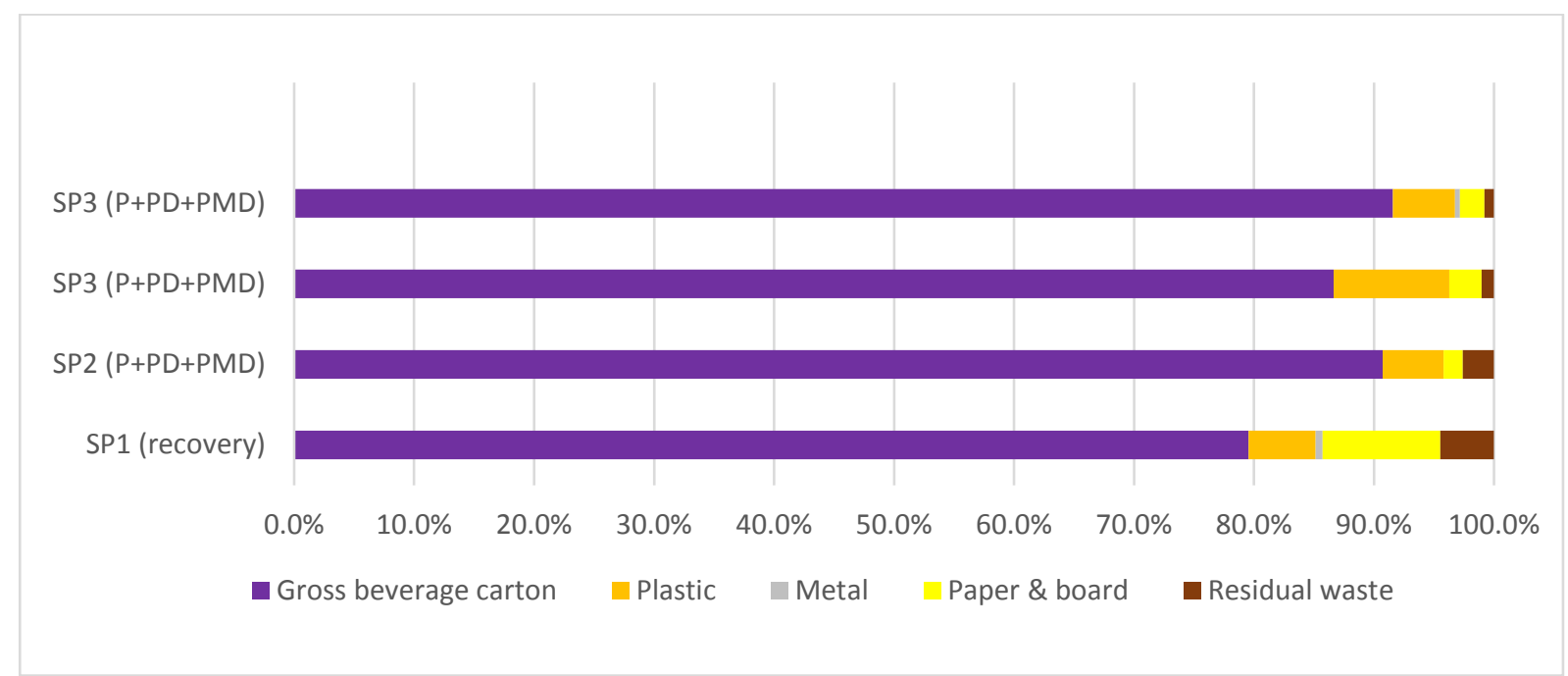

Figure 10: Material composition of sorted beverage carton products.

The sorted products have to comply with DKR specification 510 which mentioned that the concentration of impurities should not exceed $10 \%$. As is clear from Figure 10 only two of the four sorted products comply with this specification. Non-compliance of sorted products is a larger, general issue, that is addressed by Nedvang with their monthly quality controls of all sorting companies. It is expected that Nedvang will release a more detailed report on the matter in the coming months. The limited samples studied in this study give a first impression of this problem. From interviews with directors of sorting facilities and recycling facilities it is apparent that the level of non-compliance of our 4 samples doesn't surprise them.

Of the impurities plastics and metals are least problematic, they simply reduce the recycling yield. Paper and board impurities are likely to have absorbed product residues and other liquids during collection and sorting, which can contaminate the fibre product. Organic materials as impurity can significantly downgrade the recovered fibres, giving it an odour that cannot be removed. Hence, this recycling feedstock has quality issues and these issues have risen in comparison to the pilot of 2013 when most sorted beverage carton products contained more than $95 \%$ beverage cartons. 
The precise composition in terms of types of beverage cartons is listed in Appendix A. The average total moisture and dirt content is shown in Figure 11. During the pilot 2013 this value was $25 \%$ and this more or less is still the same, although the variation is substantial.

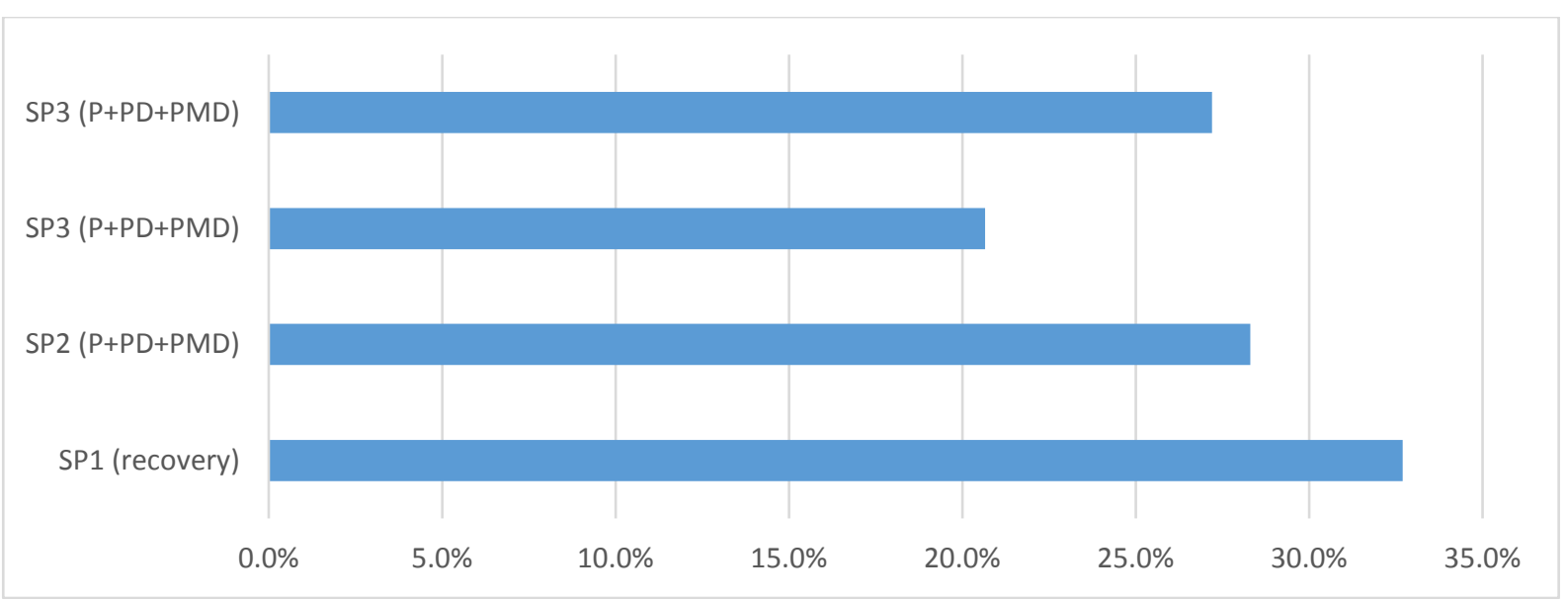

Figure 11: averaged total MDC levels for sorted beverage carton products.

\subsubsection{Concentrations of beverage cartons in other sorted products}

The average concentration of beverage cartons in sorting products other than beverage cartons is given in Table 10. For the PET, PE, PP and Film sorting production these concentration were derived by analysing photos made of the category 'other materials' during the monthly quality controls of Nedvang. The concentrations of beverage cartons in the other were obtained from manually sorting MIX, sorting residues and Non-ferrous metals.

Table 10: average concentrations of beverage cartons in sorting products made from selective collected packaging materials in the Netherlands in 2016.

\begin{tabular}{|l|c|}
\hline Sorted product & Average concentration of beverage cartons \\
\hline PET & $0.04 \pm 0.03 \%$ \\
\hline PE & $0.07 \pm 0.03 \%$ \\
\hline PP & $0.13 \pm 0.06 \%$ \\
\hline Film & $0.05 \pm 0.03 \%$ \\
\hline MIX & $1.7 \pm 0.5 \%$ \\
\hline Metals & $3 \pm 4 \%$ \\
\hline Sorting residues & $5 \pm 2 \%$ \\
\hline
\end{tabular}

With these concentrations, gross masses of collected materials (see paragraph 3.2) and the gross masses of sorted products (obtained from Nedvang and sorting companies) a first mass balance was established, see Appendix B. This data was entered in STAN for data reconciliation.

The output of STAN is graphically shown in Figure 12. The DRQ value was 0.48, indicating that 
the quality of the reconciled data was fairly low, which is most likely caused by the large uncertainties in the net amounts of beverage cartons that were present in the collected materials.

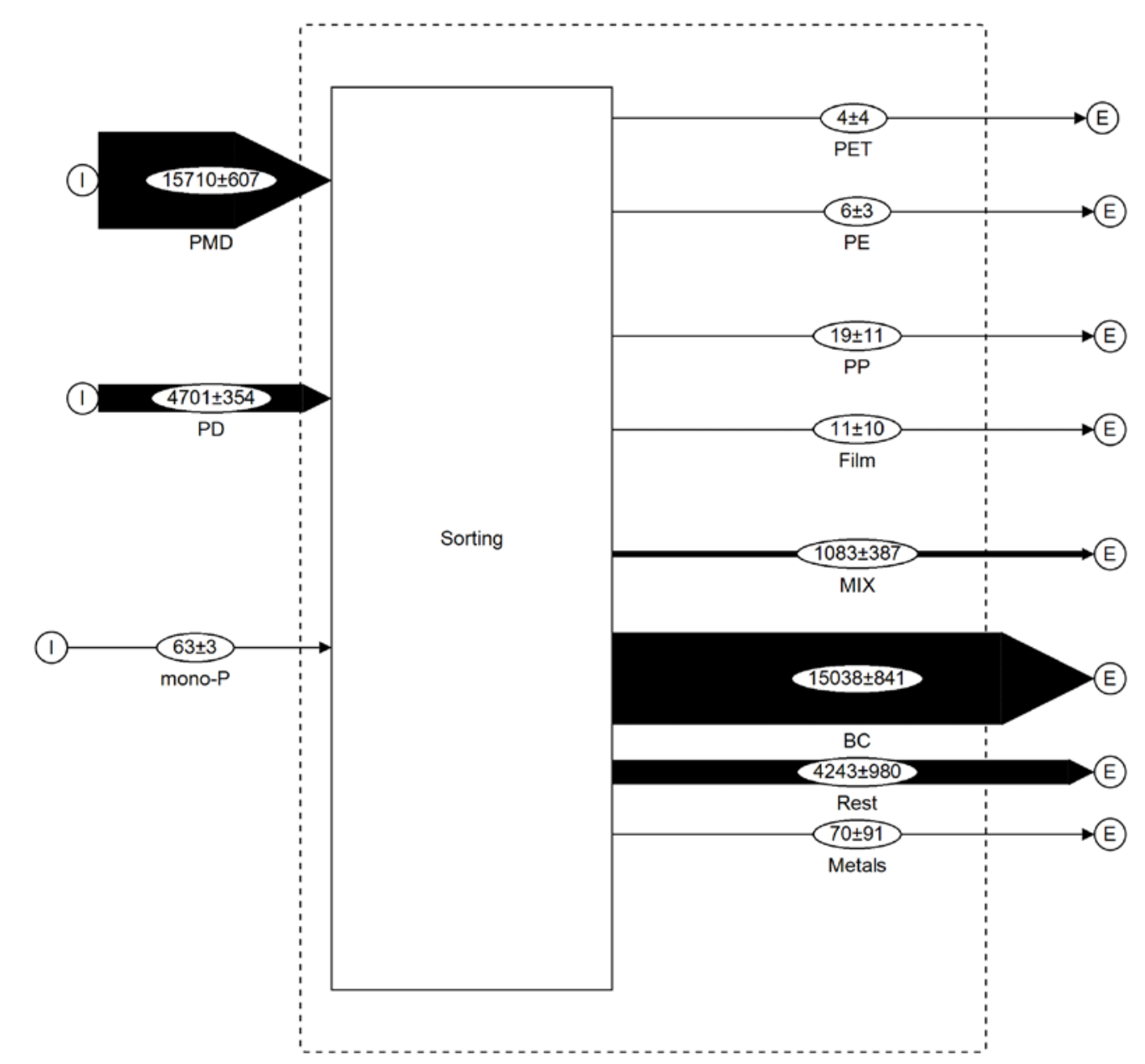

Figure 12: Reconciled data for the sorting process of beverage cartons that are present in the three types of separately collected packaging wastes (Mono-P, PD and PMD) that underwent sorting in 2016 with regard to the beverage cartons [tonne net].

The sorting division of the separately collected beverage cartons over the sorted products is shown in Figure 13. As is eminent from this pie-chart $73 \pm 5 \%$ of the beverage cartons end-up in the beverage carton product. The method for calculation the error in this sorting yield $(5 \%)$ is explained in paragraph 2.4.2.

The calculated large loss to the sorting residues is the result of the large variation in beverage carton concentrations determined for sorting residues from various sorting facilities. During the reconciliation procedure, the values with the largest uncertainty will be adjusted the most to achieve agreement between the input and output data. 


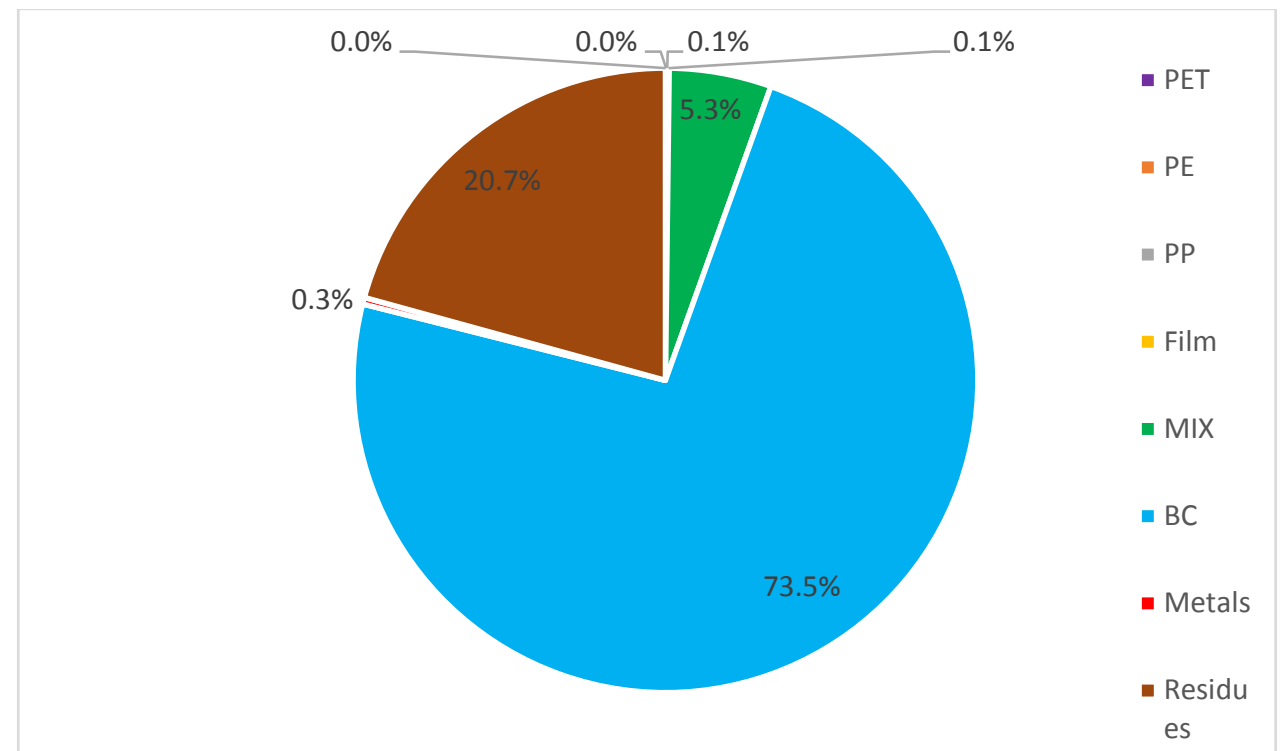

Figure 13: Sorting division of the separately collected beverage cartons from mono-P, PD and PMD over the sorted products. 


\subsection{Mass flow schemes and net chain yields}

The gathered data has been combined in mass flow scheme's. The most simple mass flow scheme of the separate collection of only beverage cartons is shown in Figure 14. The others are more complicated since they also contain a sorting step and these are collected in Appendix C.

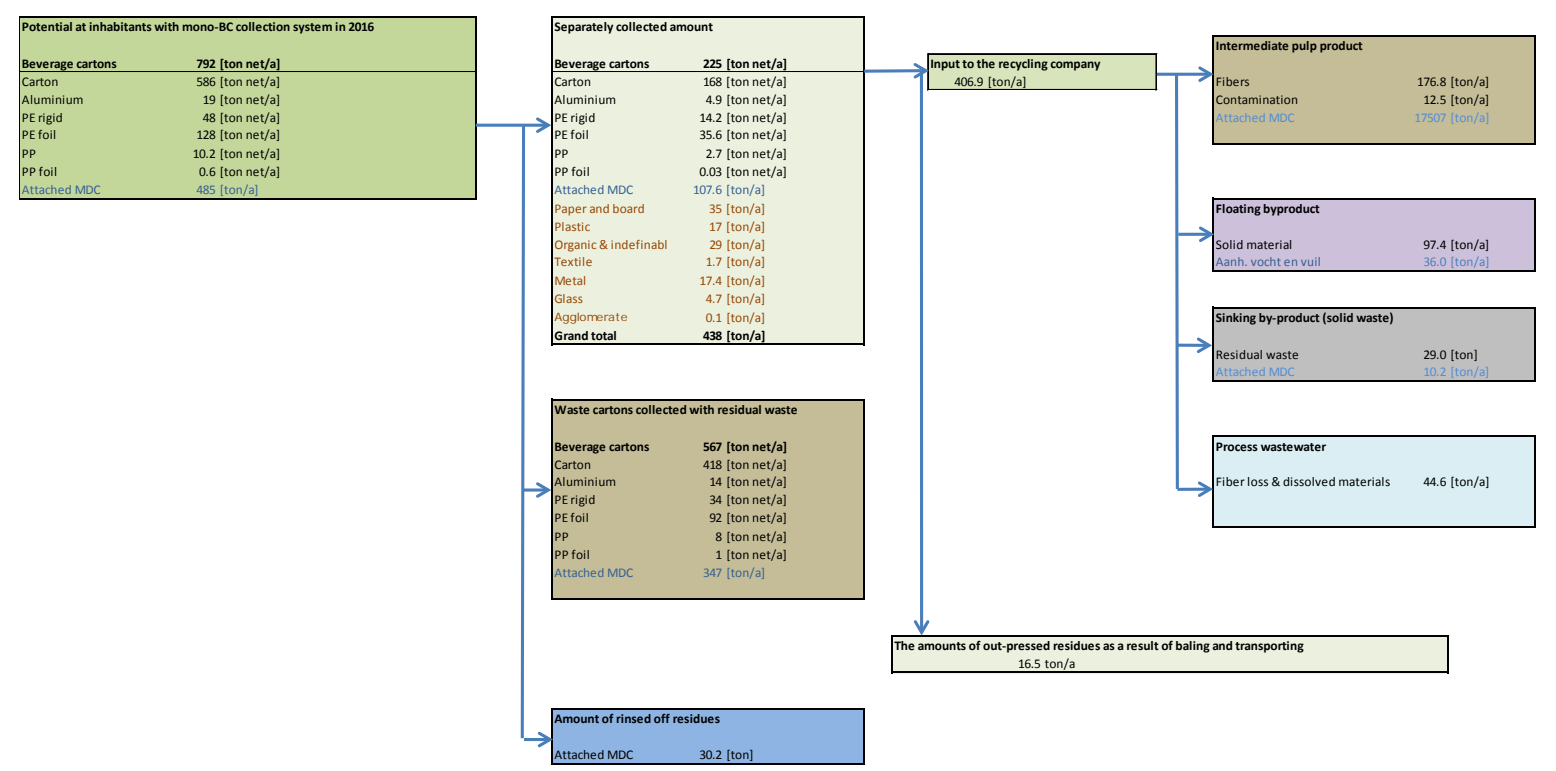

Figure 14: mass flow scheme for the 7 Dutch municipalities that operated a separate collection system for only beverage cartons in 2016.

The net material chain yields for all the studied collection \& recycling chains in 2016 have been listed in Table 11. These are material yields (and hence not mass yields), implying that they relate to net concentration of paper fibres in the beverage cartons and of the net weight of fibres in the pulp. The net materials yields of the recycling step were copied from the pilot study in 2013 . The net recycling yields in the recovery chain are printed italic, since they are based on the assumed complete collection with the MSW and a sorting yield of $75 \%$, see paragraph 2.2.4.

Table 11: The net material yields from net collected beverage cartons to net amount of pulp. N.a. means not applicable.

\begin{tabular}{|l|l|l|l|l|c|}
\hline System & 1 Collection & 2 Recovery & 3 Sorting & 4 Recycling & $\begin{array}{c}1.2 .3 .4 \\
\text { Overall }\end{array}$ \\
\hline Mono BC & $28 \pm 2 \%$ & n.a. & n.a. & $85 \pm 5 \%$ & $24 \pm 2 \%$ \\
\hline PD & $31 \pm 8 \%$ & n.a. & $73 \pm 5 \%$ & $81 \pm 5 \%$ & $18 \pm 3 \%$ \\
\hline PMD & $40 \pm 12 \%$ & n.a. & $73 \pm 5 \%$ & $81 \pm 5 \%$ & $24 \pm 4 \%$ \\
\hline Recovery & $100 \%$ & $57 \%$ & $75 \%$ & $89 \pm 5 \%$ & $38 \pm 7 \%$ \\
\hline $\begin{array}{l}\text { Mono-P (no } \\
\text { BC) }\end{array}$ & $0.7 \pm 0.1 \%$ & n.a. & $73 \pm 5 \%$ & $81 \pm 5 \%$ & $0.43 \pm 0.05 \%$ \\
\hline
\end{tabular}


The net sorting yield of beverage cartons is based on the calculations in paragraph 3.4 and is hence a combined parameter that is calculated for the mixed input of collected materials (MonoP, PD and PMD) of 2016. It is not possible to break this parameter up into the partial contributions of three different types of feedstock.

The net collection yields are strongly dependant on the national potential of beverage cartons (60 kton in 2016), an even consumption pattern throughout the country and the correct categorisation of the municipalities. Since we do know that a few municipalities (e.g. Tilburg, Midden-Drenthe) operate combinations of separate collection and mechanical recovery systems, it is possible that the categorisation of these municipalities as separate collection system causes a slight over-estimation of the net collection yield for these municipalities. Since only a limited amount of municipalities are expected to have such a combined recycling system, it is expected that the impact on the net collection yield is limited.

\section{Comparison with net yields from 2013.}

The net material chain yields are roughly similar to those determined in 2013 [Thoden van Velzen et al 2013], although there are several minor changes. The net material yield for separate collection of only beverage cartons has risen from 16 to $24 \%$. The seven municipalities that operate this separate collection system, do that already for many years and hence the response is matured within these years. Simultaneously the amount of municipalities that operate a mono-BC collection system has reduced enormously between the pilot of 2013 (23) and 2016 (7). The responses from this smaller, more homogeneous group of municipalities is likely to be higher. An additional partial explanation became apparent when the Wastetool-response data was compared to the PwC-response data (see paragraph 4.1); some of these Mono-BC municipalities are engaged in mechanical recovery of their MSW as well and hence the Wastetool-data overestimates the Mono-BC collection response.

In 2013 two different PD collection systems were studied. The Milieuzakken-system with a net recycling chain yield of $46 \%$ and a then new group of pilot municipalities with a net chain yield of $11 \%$. The net overall recycling chain yield for all the municipalities with a PD collecting system in 2016 was $18 \%$, which is in reasonable agreement with the numbers of 2013 . Although the number is lower than what is was for the Milieurakken, this is easily explained due to the more heterogeneous nature of the current list of PD municipalities. Furthermore, also the higher average net chain yield of $18 \%$ compared to $11 \%$ can be understood as a maturation effect of the overall collection system.

The overall net chain collection yield for the PMD collection system was $24 \%$ and hence in average slightly higher than the average for the PD system. This effect can either be contributed to the expansion of the portfolio and also to simultaneously taken measures, such as changes in the collection frequency of the packaging materials and MSW and changes in the collection method such as from bags to mini-containers etc. 
For both the PD and the PMD system, the net chain yields can also be calculated for the different types of collection systems that are discerned, see Table 12. These net chain recycling chain are governed by the net collection yields, since the sorting and recycling yields are equal for the PD and PMD collection systems. As is obvious, the net chain yields vary strongly with the collection systems and are higher for kerbside collection systems than for drop-off, higher for municipalities with a PAYT system than for municipalities without and higher for municipalities with less than $50 \%$ high rise buildings than for municipalities with more of these buildings. It also shows that the highest net recycling chain yields for a separate collection system are in the order of $43-45 \%$.

Table 12: Net recycling chain yields for the various PD and PMD collection systems.

\begin{tabular}{|c|c|c|}
\hline System & $\begin{array}{c}\text { Net collection yield, } \\
{[\%]}\end{array}$ & $\begin{array}{c}\text { Net recycling chain yield, } \\
{[\%]}\end{array}$ \\
\hline PD DO NP < 50\% & $11 \pm 6 \%$ & $7 \pm 3 \%$ \\
\hline PD DO NP $\geq 50 \%$ & $6 \pm 2 \%$ & $3 \pm 1 \%$ \\
\hline $\mathrm{PD} D O \mathrm{PA}<50 \%$ & $39 \pm 16 \%$ & $23 \pm 10 \%$ \\
\hline PD KS NP $<50 \%$ & $43 \pm 3 \%$ & $25 \pm 3 \%$ \\
\hline $\mathrm{PD} K S \mathrm{PA}<50 \%$ & $75 \pm 13 \%$ & $45 \pm 9 \%$ \\
\hline $\mathrm{PD}$ CO NP $<50 \%$ & $48 \pm 20 \%$ & $29 \pm 12 \%$ \\
\hline PD Total & $31 \pm 4 \%$ & $18 \pm 3 \%$ \\
\hline PMD DO NP $<50 \%$ & $19.0 \pm 0.6 \%$ & $11 \pm 1 \%$ \\
\hline PMD DO NP $\geq 50 \%$ & $5.0 \pm 0.4 \%$ & $2.9 \pm 0.4 \%$ \\
\hline PMD DO PA $<50 \%$ & $57 \pm 4 \%$ & $34 \pm 4 \%$ \\
\hline PMD KS NP $<50 \%$ & $33 \pm 3 \%$ & $20 \pm 3 \%$ \\
\hline $\mathrm{PMD} K \mathrm{KS} N \mathrm{NP} \geq 50 \%$ & $19.0 \pm 0.6 \%$ & $11 \pm 1 \%$ \\
\hline $\mathrm{PMD} K \mathrm{KS} \mathrm{PA}<50 \%$ & $62 \pm .5 \%$ & $37 \pm 4 \%$ \\
\hline PMD CO NP $<50 \%$ & $42 \pm 8 \%$ & $25 \pm 5 \%$ \\
\hline PMD CO NP $\geq 50 \%$ & $61 \pm 4 \%$ & $36 \pm 4 \%$ \\
\hline $\mathrm{PMD} \mathrm{CO} \mathrm{PA}<50 \%$ & $73 \pm 10 \%$ & $43 \pm 7 \%$ \\
\hline PMD total & $40 \pm 6 \%$ & $24 \pm 4 \%$ \\
\hline
\end{tabular}

In 2013 two mechanical recovery chains were studied, which gave two different values for the overall net chain yield, namely 38 and $63 \%$. In this study we calculate an overall yield of $38 \pm 7 \%$ for 2016. The overall number is now lower than the average of the two numbers in 2013. This is most likely caused by the categorisation of municipalities with combined separate collection and recovery systems as separate collection systems. This has multiple consequences. One of the consequences is that a large part of the MSW which is subjected to mechanical recovery is depleted in beverage cartons, due to the presence of the separate collection system. This reduces the efficiency of the recovery process. 


\subsection{Cross contamination}

Before this research project started, the hypothesis was that due to the relative high moisture and dirt contents (MDC) of Dutch beverage cartons cross-contamination of these residues to the other co-collected packages will happen during collection and sorting. This would be especially relevant in co-collection systems such as PD and PMD co-collection.

However, the results of this study do not directly support this hypothesis. The MDC of plastic packages collected together with beverage cartons and metal packages in PMD material is inaverage equal to the MDC of separate collected plastic packages from before 2014, see 3.3.1. This means no cross contamination from beverage cartons to plastic packages has occurred in the loose collected material. This appears to contradict with the observations of representatives of sorting facilities and recycling facilities that both collected material and the sorted products have been become dirtier, smellier and more prone to infestation. From 2015 on, one sorting facility treats all the collected materials with insect repellents and biocides. Two other sorting facilities only treat susceptible sorting products with anti-odour-enzymes and biocides such as MIX and beverage cartons when it is necessary (usually when the outside temperature rises above $10^{\circ} \mathrm{C}$ ). One partial explanation for these observations is that the fraction of residual waste of the collected PMD material has increased (see paragraph 3.3.5) of which a part is organic material and indefinable objects, which are also distributed over the sorting products (see paragraph 3.4.1).

The second partial explanation is that when the collected material is pressed in collection vehicles, transport vehicles and bale presses the contained residues are released from the cartons and spread over the neighbouring packages. Since small amounts of beverage cartons also end up in the plastic sorting products (see 3.4.2), this also contributes to the contamination of the plastic sorting products with product residues from beverage cartons during the baling of these sorting products. Note that 4 municipalities were sampled directly on the street, because the side-feeding collection vehicles (that press the collected material) could not sampled (see 2.1.5), hence by studying the loose material, we are likely to have missed the cross-contamination. Both partial explanations raise the level of food residues on the surface of plastic packages and hence give better growth conditions for micro-organisms and insects.

A third possible partial explanation is the reduced collection frequencies of packaging wastes. Several kerbside PMD collecting municipalities have introduced mini-containers and collect the contents now every 4 weeks instead of every fortnight. This increases the lead time of collection and since this PMD waste is exposed to outside temperatures, it implies that the microbiology and entomology can thrive, resulting in odours and infestation.

This implies that cross-contamination between beverage cartons and plastic packages is mostly an indirect effect. It is not detectable in loosely collected material. But due to the fact that PMD contains more residual waste and has longer collection lead times, the micro-organisms and insects receive more options to grow on the food residues present. The pressing of collected 
materials in transport trucks and the baling of sorted products with small amounts of faulty sorted beverage cartons present, squeeze out the contained food residues and spread them over the plastic packages, which enhances this growth further.

Normal cross-contamination is a mutual exchange process in which the residues between cocollected materials are exchanged during collection and sorting. However, since in Dutch beverage cartons, most of the residues are entrapped within the cartons, this exchange process only starts after a trigger is applied (pressing). And since the MDC of beverage cartons is much higher than those of plastic packages and metal packages (see paragraph 3.3.1), the net result of the exchange process after applying the trigger of pressing is a net transport of residues from the beverage cartons to the other packages.

So, in the end the hypothesis of cross-contamination needs reformulation. It is likely that crosscontamination from beverage cartons to the other co-collected packaging materials is indeed occurring. However, this is not yet detectable in loosely collected material. The crosscontamination process only starts off after the material is pressed, either in a transport vehicle or during baling of sorting products. To complicate this issue even further, besides crosscontamination simultaneously two other factors deteriorate the quality of co-collected packaging materials and their sorted products. First, the collected packaging materials contain higher levels of residual waste. Second, the longer collection lead-times also contribute to the reduction in quality of recycled packaging materials.

So, the hypothesis can be (and will be in the near future) tested by measuring the MDC levels of plastic packages in sorted products made from PMD collection in 2017 and comparing those levels to previously measured MDC levels (2013) on sorting products made from mono-P collection system. Although this will present new evidence, it cannot confirm the hypothesis, due to the two other factors. Only a relatively complicated technical test in which the collection and sorting processes are well-controlled can be used to definitely confirm the cross-contamination hypothesis.

\subsection{Quality decay experiment of paper fibres}

The hypothesis prior to this project was that the quality of paper fibres inside beverage cartons will deteriorate during storage of collected beverage carton waste. The idea was that, during emptying, discarding, collection and sorting, the beverage cartons are subjected to mechanical stress which can result in small cracks in the interior PE or PE/Aluminium film. This would allow microorganisms and especially fungi to contact the paper fibre and start degrading them. To test this hypothesis a controlled storage experiment was conducted.

The quality development of the fibres contained within Dutch beverage cartons was evaluated by testing the effect of storage for prolonged time at three different temperatures $\left(4,20\right.$ and $\left.40^{\circ} \mathrm{C}\right)$. Two different samples were tested, a sorted product from separate collection, named: SP $(\mathrm{P}+\mathrm{PD}+\mathrm{PMD})$ was obtained on 23 August 2017 and a sorted product from mechanical recovery, 
named SP (Recovery) was obtained from a Recovery system on 29 august 2017. Upon arrival the samples were divided into smaller samples manually and stored at the different temperatures, large plastic and metal parts were removed. It was noted that both samples were relatively dry (Moisture content about 30\%). Little biological activity was seen during the storage up to 4 weeks for all three temperatures. The odour of the material itself was not very bad, the odour of the water after pulping the material was bad at all test moments. Apparently, a strong odour is released from the beverage cartons during the wet recycling (pulping) process. It did not matter if the beverage cartons were pulped directly after arrival or after 4 weeks. In both cases the stench was intense and caused complaints of neighbouring scientists. Additionally, this odour was found to absorb in the PE containers used for the pulping water. It proved very difficult to remove this odour from these 150 litre water containers after the pulping experiment was finished. Even after cleaning, drying and storing these containers for some time, they still released a strong smell.

\subsubsection{Pulp strength}

For the testing of the fibre strength in pulp-sheets the stored samples were pulped in a mechanical pulper (RAS-Pulper) for 10 minutes at a consistency of $2.5 \%$. In practice about 12 beverage cartons of 1 litre size were pulped per batch, or more if the sample contained smaller beverage cartons. The pulp was cleaned further from smaller size impurities with a Sommerville fractionator. A slit width of $0.15 \mathrm{~mm}$ was used. This cleaning step is necessary, because larger (plastic) particles greatly influence the mechanical properties of hand-sheets. As the Sommerville fractionator requires large amounts of water during processing, the fibres were highly diluted prior to hand-sheet production. Hand sheets were produced using a Rapid Köthen Sheet former. After conditioning, weight, thickness, Short Span Compressing Strength and tensile properties were determined according to ISO 536, ISO 534, ISO 1924-2 and ISO 9895. The results of all measurements are presented in Appendix D. Both the short span compression strength and the tensile strength of the hand-sheets are an indication of the fibre strength and the bonding between the fibres. A decay in the strength of the fibres due to prolonged storage would be visible in these two parameters. In Figure 15 the tensile strength of hand-sheets made from SP $(\mathrm{P}+\mathrm{PD}+\mathrm{PMD})$ is shown as a function of storage time and storage temperature. The tensile strength of the samples shows large variations over time. This is caused by the fact that each data point was measured starting with different beverage cartons. There is no clear deterioration of the tensile strength due to prolonged storage. There is no significant difference between the samples stored at the three different temperatures. 


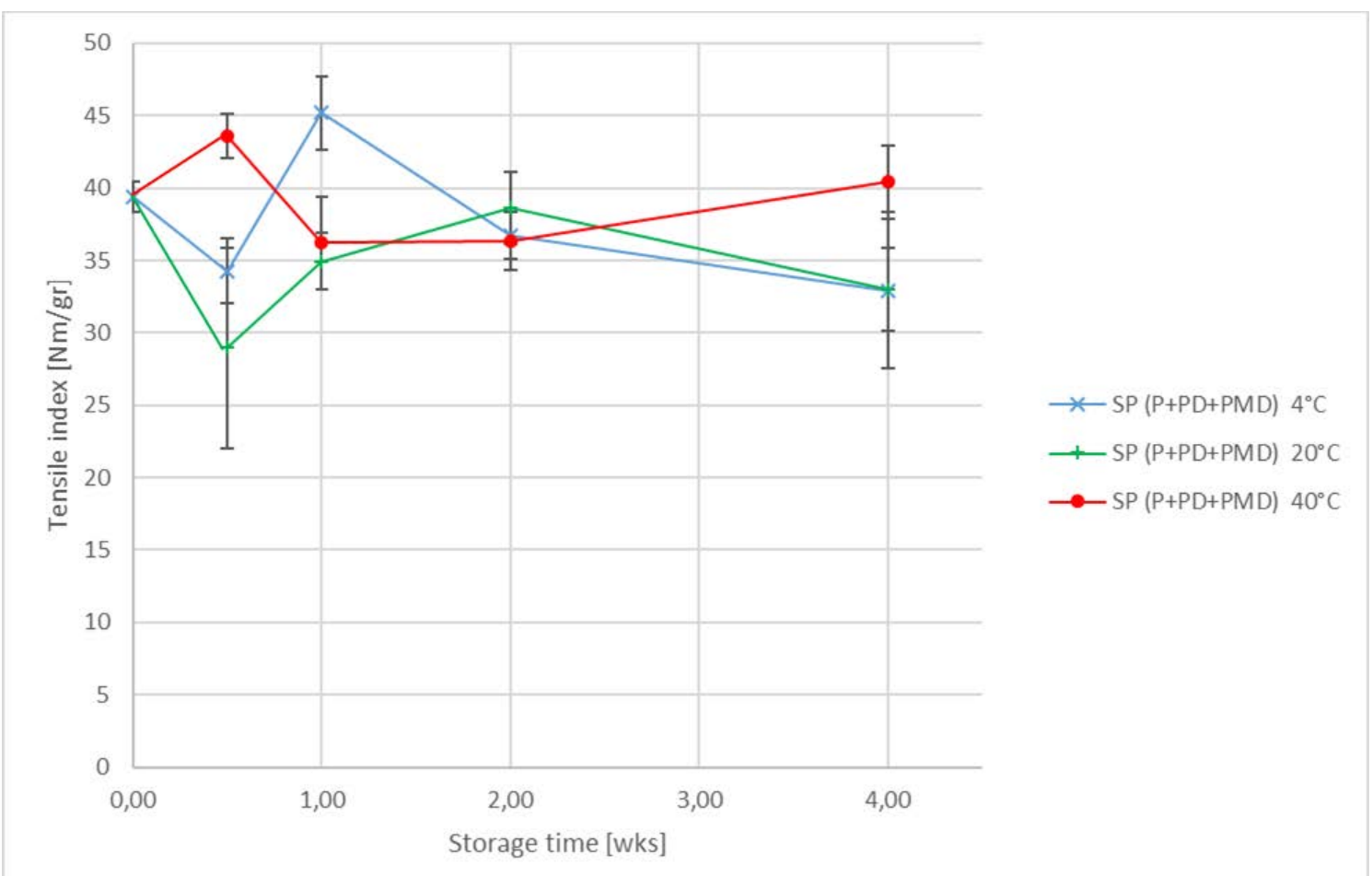

Figure 15: Tensile strength of hand-sheets made from $S P(P+P D+P M D)$ after storage at different temperatures.

In Figure 16 the tensile strength of hand-sheets made from SP (Recovery) is shown as a function of storage time and storage temperature. Again there is no indication of deterioration of the tensile strength due to prolonged storage.

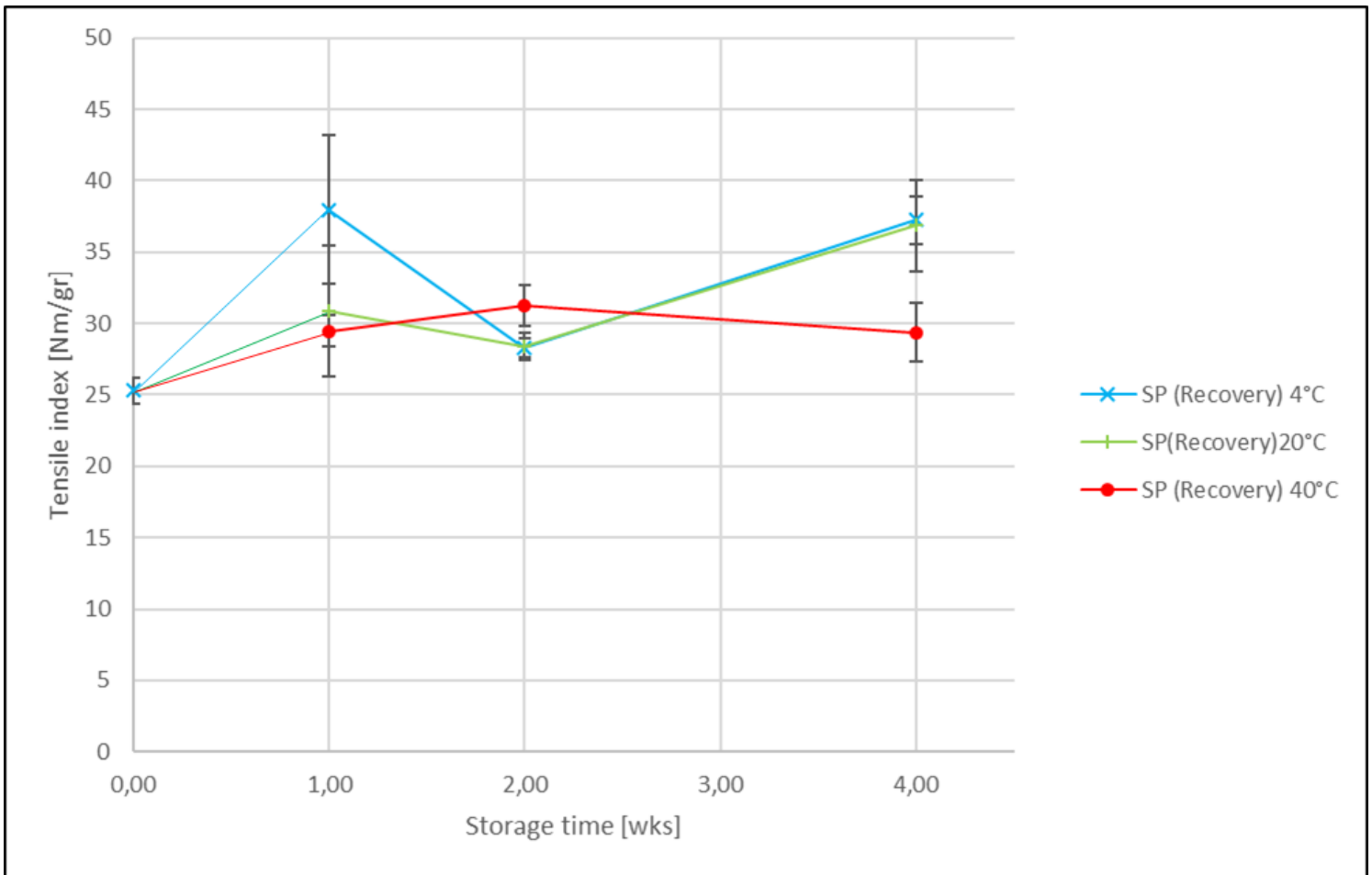

Figure 16: Tensile strength of hand-sheets made from SP (Recovery) after storage at different temperatures. 
In Figure 17 the Short span compression strength (SCT) of hand-sheets made from SP $(\mathrm{P}+\mathrm{PD}+\mathrm{PMD})$ is shown as a function of storage time and storage temperature. SCT is a measure of the force needed to bend a piece of paper by compression. It can e.g. be used as an indicator on how many cardboard boxes can be stacked before one collapses. The fibres used in beverage cartons have relatively high SCT properties. The figure shows that there is no significant deterioration of the SCT due to the prolonged storage time. There is no significant difference between the results for the different storage temperatures.

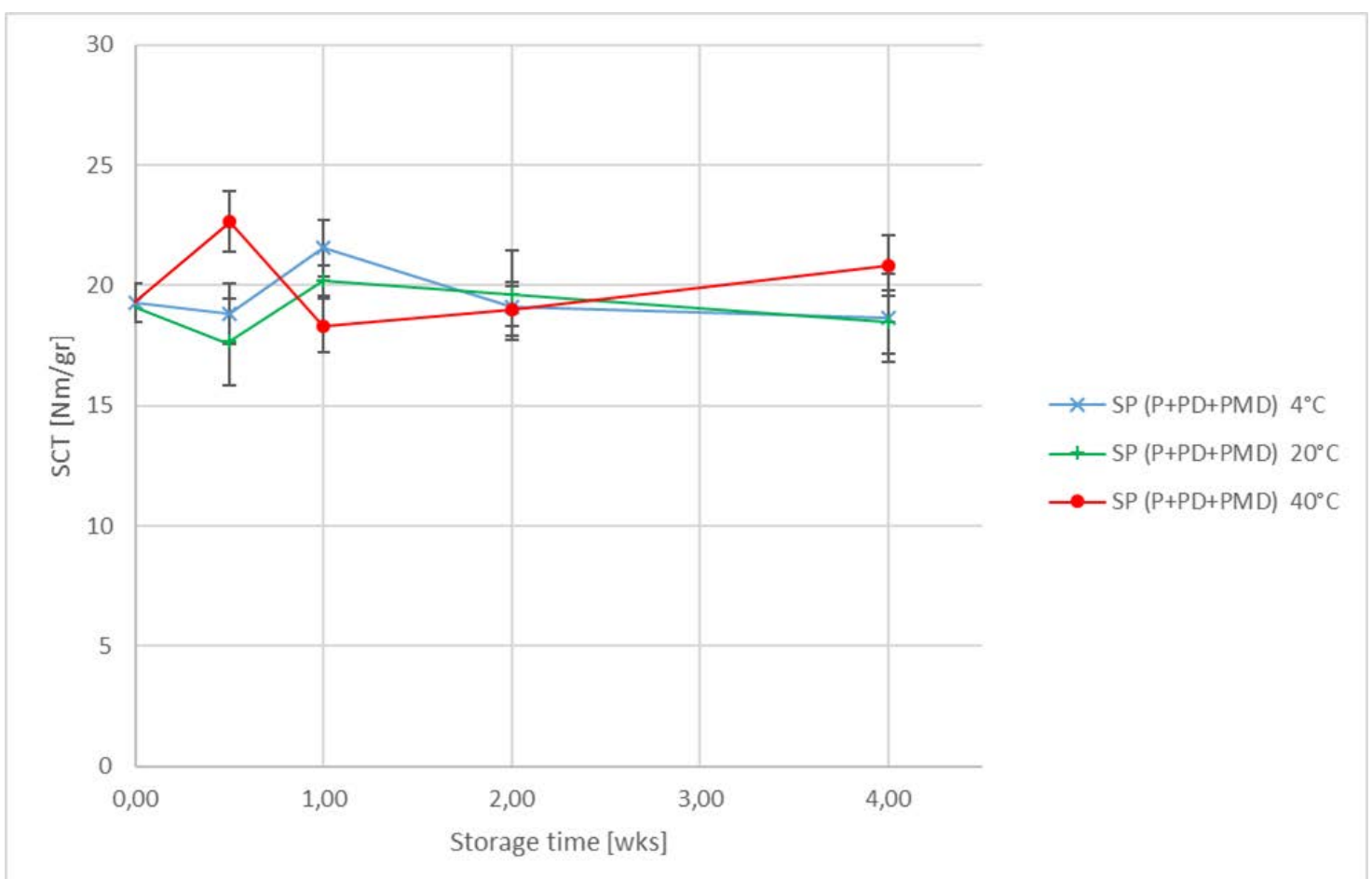

Figure 17: SCT of hand-sheets made from $S P(P+P D+P M D)$ after storage at different temperatures.

In Figure 18 the SCT of hand-sheets made from SP (Recovery) is shown as a function of storage time and storage temperature. Again there is no indication of deterioration of the SCT due to prolonged storage. 


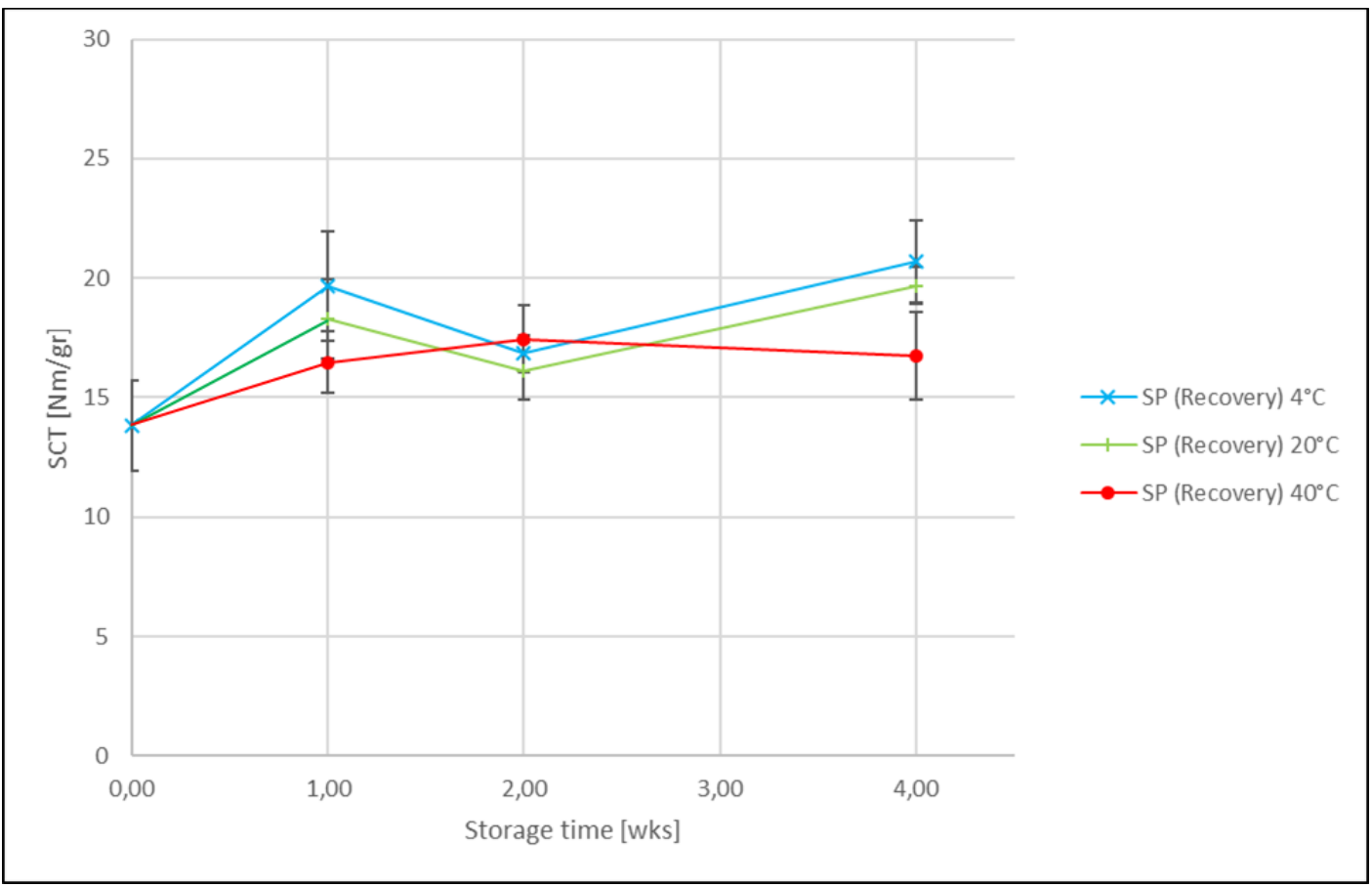

Figure 18: SCT of hand-sheets made from SP (Recovery) after storage at different temperatures

\subsubsection{Fibre length characterisation}

For the fibre length qualification the stored samples were pulped in a mechanical pulper (RASPulper) for 10 minutes at a consistency of $2.5 \%$. Part of the pulped sample was fractionated using a Sommerville fractionator (slit width of $0.15 \mathrm{~mm}$ ) followed by a Bauer-McNett classifier. The impurities present in the samples had a large influence on the measurements. Ideally the length of the fibres should be measured without influence of (non-wood) impurities. In practice the largest fraction (particles with a width over $0.15 \mathrm{~mm}$ ) contained mostly plastics. E.g. an extra plastic cap in this fraction has a high influence on the fractionation results. The smallest screen $(0.074 \mathrm{~mm})$ was sometimes blocked by very fine impurities, possibly product residues from within the beverage cartons. These two problems resulted in large variations in the results of the fractionation. All results are given in appendix D. To still be able to see the effect of prolonged storage time at different temperatures on the fibre length, only the three middle fractions were evaluated:

1) The longest fibres with a length of more than $1.19 \mathrm{~mm}$ (mostly softwood fibres) and a width smaller than $0.15 \mathrm{~mm}$,

2) the middle fibres with a length between 0.595 and $1.19 \mathrm{~mm}$ and

3) the smaller fibres with a length between 0.149 and $0.595 \mathrm{~mm}$.

In Figure 19 and Figure 20 the relative mass fraction of these three fractions are shown, as a function of storage time and storage temperature. 


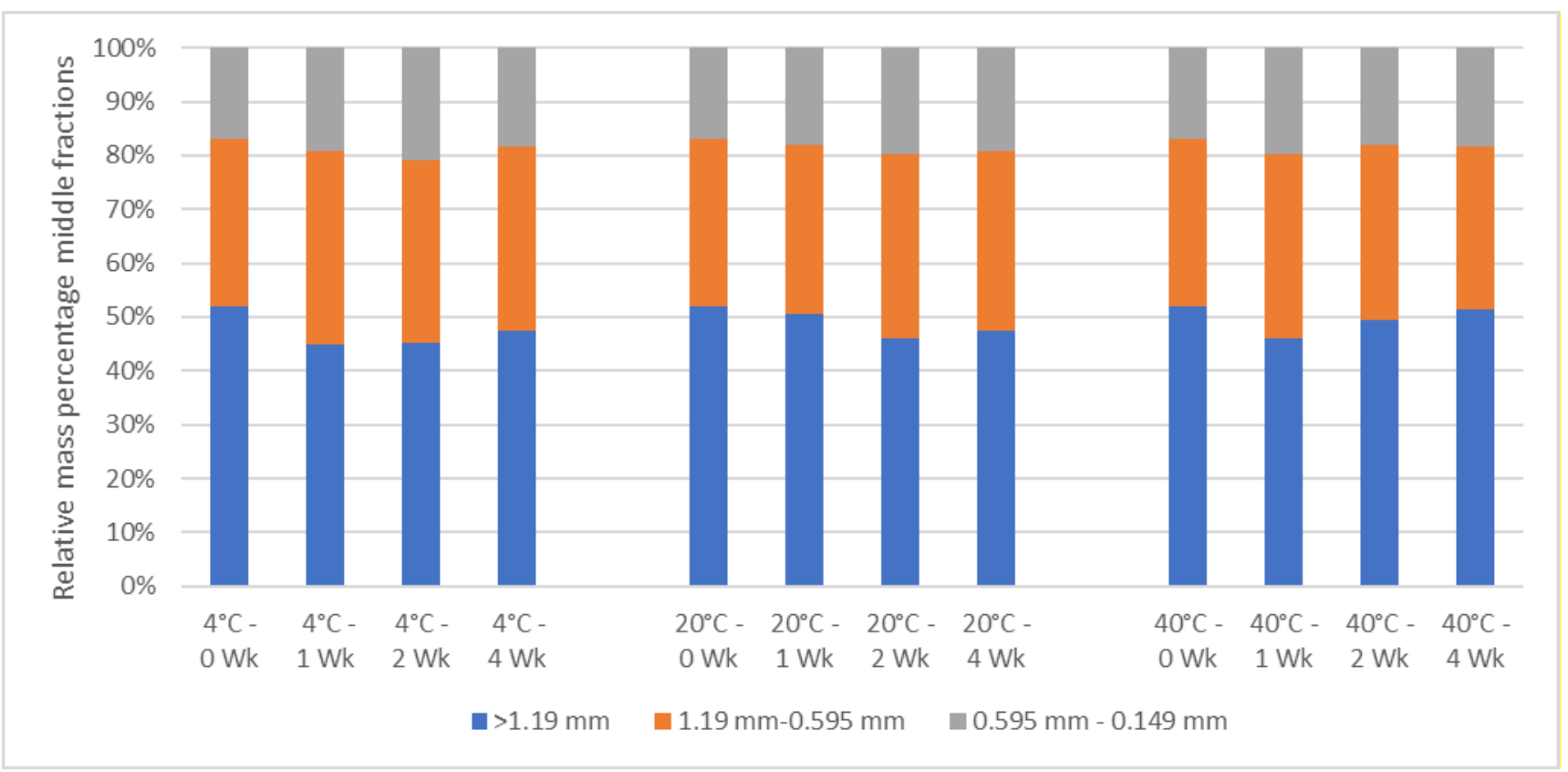

Figure 19: Fibre length characterisation of SP (Recovery) after storage at different temperatures.

Figure 19 shows the results for the storage trials with SP (recovery). The fraction with the longest fibres at the bottom and the fraction with the smallest fibre at the top. There is no significant decrease in fibre size visible.

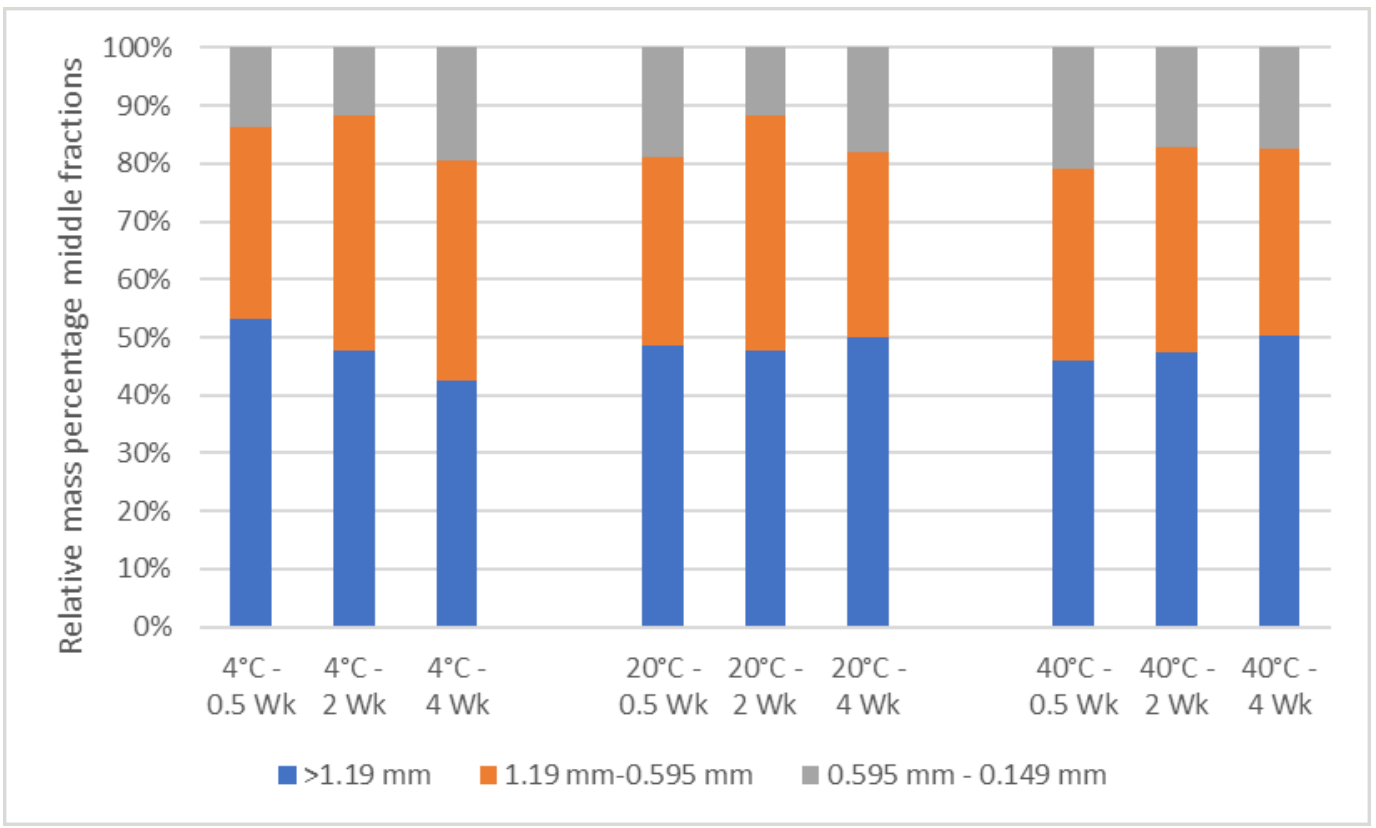

Figure 20: Fibre length characterisation of SP $(P+P D+P M D)$ after storage at different temperatures. 
Figure 20 shows the results for the storage trials with SP (P+PD+PMD). The fraction with the longest fibres at the bottom and the fraction with the smallest fibre at the top. There is no significant decrease in fibre size visible.

Both the mechanical properties of the hand-sheets made from the beverage cartons and the fibre length characterisation gave no indication of significant decay of the fibres after prolonged storage at the temperatures and conditions used in these trials.

Based on these results, the hypothesis has to be refuted. Apparently, the paper fibres inside the beverage cartons are in general well protected from microbial decay by the inner and outer films. Storage at various temperatures and time duration does not alter this; the paper fibres are still well protected within the plastic film layers. Nevertheless, this research also revealed that during the recycling (pulping) process a very strong odour is released. The strength of this odour is not influenced by the storage time and temperature; it is already very strong when pulping on the day of arrival. This is a very negative quality attribute of the feedstock of Dutch beverage cartons that has to be managed. It is likely that this strong odour originates from the product residues that are contained within the beverage cartons. The normal lead times from the moment the beverage carton is discarded to the moment the beverage carton is recycled can differ from 1 to 3 months, but during 2016 and 2017 several sorting facilities also processed packaging waste that had been stored for 1 and 2 years. The beverage cartons are stored in mini-containers and storage halls at ambient conditions and hence the contained product residues start to rot. Since the contained residues are a mix of dairy products (milk, yoghurt, custard) and juices, multiple microorganisms can grow and form typical odours associated with the anaerobic decay of proteins, such as pungent amines and sulphides. Since, the beverage cartons in 2016-2017 had lead times of months to years, this odour was already fully developed when the beverage cartons arrived at our facility. This odour can be mitigated by reducing the lead times and asking the consumer to rinse their emptied beverage cartons with cold water prior to collection.

In short, the hypothesis has to be refuted. Storage time and temperature do not negatively affect the quality of the recovered fibres from Dutch beverage cartons. However, during the recycling process a strong odour is released which does limit the recycling options and places additional demands on the recycling process. Hence, odour is the true quality-limiting factor for recycled Dutch beverage cartons.

Although establishing a difference in quality of fibres originating from separate collection and mechanical recovery was outside the scope of this project, it is tempting to evaluate a potential difference in quality based on these results. No significant difference in pulp strength and fibre length was found between the two samples obtained. However, the data generated in this project is not well suited for a comparative analysis. Much more samples should be evaluated to establish a difference in quality of fibres originating from different collection systems. 
The tests at WFBR were performed on real-life samples from two different collecting systems and stored up to 4 weeks. No significant effect on fibre quality was found. The experience from the paper industry shows that prolonged storage (more than a half year up to three years) does result in a decrease in fibre quality and discolouration. Other extreme conditions (storage under very wet conditions, large damages to the outer surface of the beverage cartons) may also result in a decrease in fibre quality.

\subsection{Perspective of the recycling industry}

The three recycling industries that are most involved with processing beverage cartons from the Netherlands are, in alphabetic order; Delkeskamp in Nortrup, Niederauer Papiermühle in Kreuzau and WEPA Nederland in Swalmen. All three recycling facilities have invested in equipment to process beverage cartons and hence have become partially dependent on this feedstock.

Representatives of all three recycling facilities have expressed their concern regarding the quality of sorted beverage cartons from the Netherlands; especially the odour and infestation of sorted beverage cartons strongly limit their applicability. Two of the three recycling facilities are located in populated areas, where the strong odours and infestation with especially flies are causing neighbours to complain. This has resulted in a reduced intake of Dutch beverage cartons for one facility.

A second facility was forced to stop processing Dutch beverage cartons from May 2017 on, due to complains from neighbouring civilians regarding flies. They have invested in an upgraded waste water treatment facility and in several technical measures to mitigate the odour emission from the storage and processing halls. They are planning to restart with processing Dutch beverage cartons from the end of November 2017 on.

The third facility is located in a forest with only a small village in the neighbourhood and quality issues could still be managed there. Although this facility also experienced issues with the waste water treatment and they also had to invest in it and hence have dealt with the odour issues. For 2016 and 2017 this facility has processed most of the Dutch beverage cartons from both separate collection and mechanical recovery. This is, however, not a long term durable situation, since the latter facility has only a 20 kton annual processing capacity and the Netherlands has produced roughly 20 kton's of sorted beverage cartons in 2016. With the reopening of the second facility end November 2017 a more healthy market situation will emerge.

Nevertheless it is in the interest of all three recycling facilities that the quality issues with Dutch beverage cartons are resolved. There are many partial solutions to the quality issues. The first one, which is the relative most easily implemented, is to change the sorting policy and to produce less contaminated sorted products. Other partial solutions involve collection policies and consumer discarding behaviour. Ideally from a quality point of view, the beverage cartons would be rinsed with cold water by the consumer to reduce the contained residues, flattened and closed. Changes in consumer behaviour require, however, years of campaigning. Furthermore, a 
reduction in the collection-to-recycling lead times could also help to keep microbial growth and hence odour formation under control.

The levels of residual waste in sorted beverage carton products is a general concern for all recycling companies. Representatives of the recycling facilities would like the sorted beverage cartons to contain less residual waste and to raise the level of compliance to the DKR 510 specification. For some recycling companies, it is a reason to return the sorted products, since the quality of their paper products can no longer be guaranteed. For other recycling companies it reduces their profitability and makes their process more labile. All companies agree that the problems associated with non-compliance of sorted beverage carton products has increased since 2013 (see paragraph 3.4.1).

\section{Recycling of by-products}

With regard to the recycling of the by-products (predominantly composed of PE, PP and Aluminium), there have been various initiatives and tests between 2013 and 2017. The majority of the by-products is still being sold as fuel to cement kilns. Tests have been performed to convert the by-products into a re-granulate (with the aluminium mixed in as tiny flakes in the PE matrix). These applications, however, suffered from odour issues that were difficult to resolve. According to the director of WEPA Nederland, these odour issues were resolved. However, currently the by-products are still sold to cement kilns.

The new pyrolysis facility of Fuenix in Weert is claiming to target the beverage carton rejects as a feedstock (amongst other plastic wastes) and hence we might see results of these tests in 2018. This would then result in the conversion of the plastics in the by-products into various breakdown products (naphtha, fuels, gas, etc.) and in the recovery of the aluminium flakes [Mellema 2017]. These tests will have to answer the questions whether or not this process is profitable and whether or not the process can handle the contaminants present. Besides pyrolysis also other processes are being tested, according to directors of beverage carton recycling facilities. This only indicates that the end-of-life-fates of the by-products could potentially change in the future. 


\section{Discussion}

\subsection{Quality of the input response data}

The calculations in this project are based on the gross collected amounts that municipalities entered in Wastetool for the year 2016, both for "plastic packages" and for "beverage cartons". This data was offered to us by Nedvang in May 2017 for use in this study and encompassed all the 390 municipalities.

Since we received indications from civil servants that this data doesn't always relate to the gross total collection response (including attached moisture and dirt and other co-collected packaging materials), a cross-check was performed with the gross total responses that PwC collected (and verified as accountants) for 80 municipalities, roughly $20 \%$ of the population. This comparison between both data sets of gross collection responses revealed substantial differences. Roughly half of the municipalities had the same or nearly the same response, but the other half deviated substantially. Subsequently attempts were made to add up the entered plastic packaging response and the beverage carton response in Wastetool and to compare that to the $\mathrm{PwC}$ dataset. That did not improve the comparison. Therefore, it was decided to calculate the difference in annual gross specific responses, according to Equation 7.

$$
\Delta C R=C R^{P w C}-C R^{W T P L P a}\left[\frac{\mathrm{kg} \text { gross }}{\text { cap.a }}\right]
$$

Equation 7: The difference in gross total collection response was calculated as the difference between the response according to $P_{W} C$ (for a full year) and the response entered in Wastetool for plastic packages.

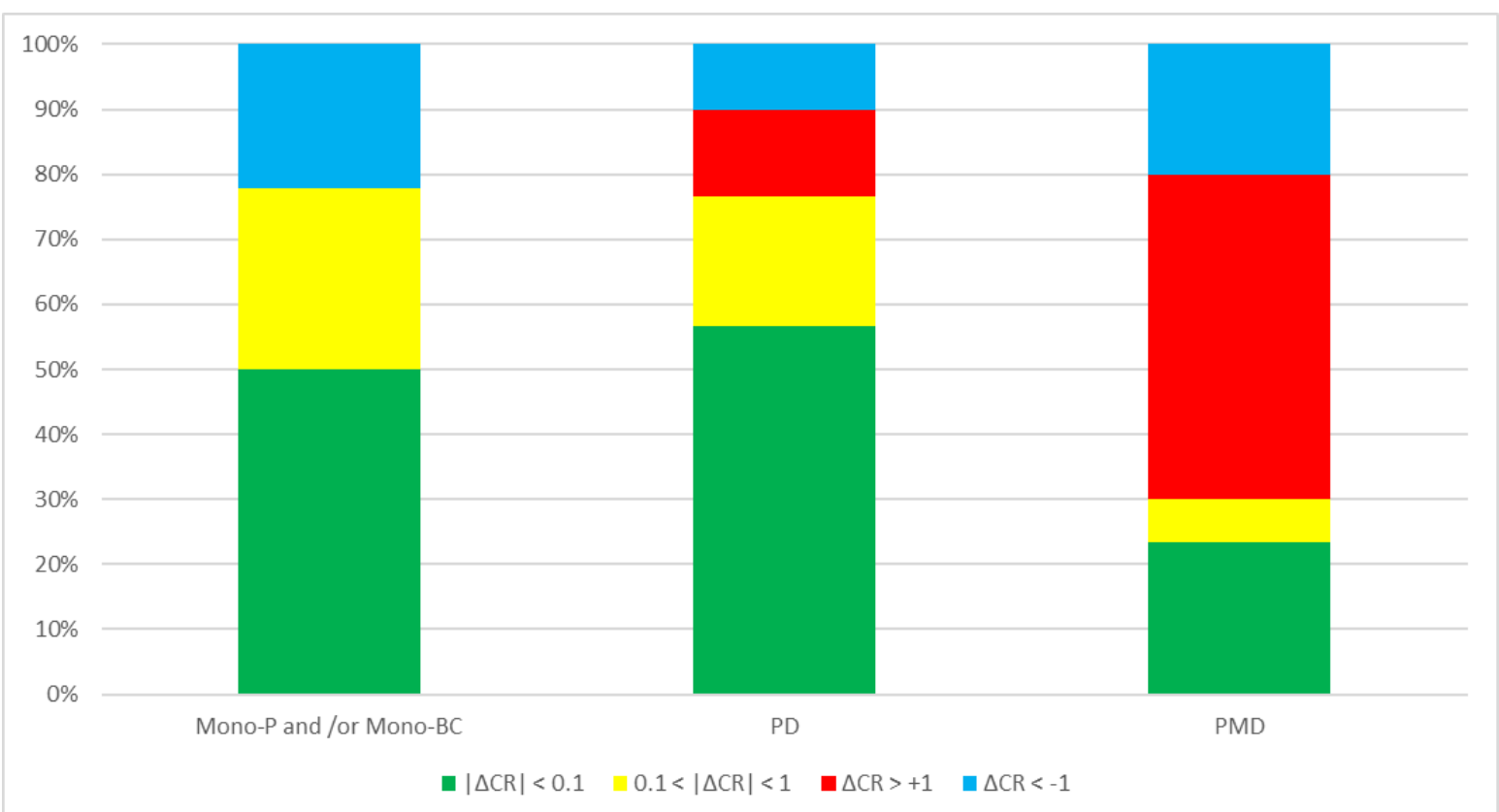

Figure 21: The difference in total gross response for 80 municipalities from the $P_{W} C$ dataset and the Wastetool dataset for plastic packages . 
In Figure 21 the difference in collection responses is shown for municipalities with three different collection systems: Mono-P and/or Mono-BC, PD- and PMD. For the mono-P and PD-collecting municipalities there is a full match in the gross responses for $50 \%$ of the municipalities and a reasonable good match for $75 \%$ of the municipalities. For PMD-collecting municipalities the data deviates much more, only a $25 \%$ full match and a $30 \%$ reasonable match in total gross collection responses.

Two types of relatively large deviations are observed; positive differences (red in figure 21) and negative differences (blue in figure 21). In case the difference is positive, the municipality registers less collection response in Wastetool as plastic packages than the actual gross total collection response according to $\mathrm{PwC}$. The likely explanation is that the civil servants apply a subtraction for non-plastic packages before entering the numbers in Wastetool. If true we could expect to find some correlation in the quotient of Wastetool response over $\mathrm{PwC}$ response. This quotient varied for most of these municipalities between 0.82 and 0.95 , which could be seen as a confirmation of this subtraction for most of the municipalities with a positive difference, but not for all.

In case the difference is negative, then the municipality reports larger gross collection responses in Wastetool than what $\mathrm{PwC}$ reported for that municipality. One of the likely explanations is that this municipality subjects its MSW to mechanical recovery and adds the weights of the sorted products from recovery to the collected amounts and enters the sum in Wastetool. Indeed for roughly half of these municipalities it is known that they operate a combined separate collection and mechanical recovery system, for the other half of these municipalities no logical explanation could be found.

The uncertainty that the use of the gross collection responses from Wastetool introduces in the calculations was estimated by taking the sum of the differences and dividing that by the amount of municipalities from which the two response data were compared, see Equation 8 and Equation 9. The calculated standard deviations are listed in table 13.

$$
S D(\text { use of WT data })=\sqrt{\frac{\sum_{0 \rightarrow n}(\Delta C R)^{2}}{n-1}}\left[\frac{\mathrm{kg} \text { gross }}{a}\right]
$$

Equation 8: The standard deviation due to the use of the Wastetool-data was calculated from the differences in response in the $P_{W} C$ dataset with the response in the Wastetool dataset divided by the amount of municipalities in that category (n).

$$
R S D\left(\text { use of WT data) }=\frac{S D \text { (use of WT data) }}{\sum_{0 \rightarrow n} C R^{W T P l P a}}[\%]\right.
$$

Equation 9: The relative standard deviation due to the use of the Wastetool-data was calculated by dividing the standard deviation with the sum of collection responses for that group of n municipalities in Wastetool. 
Table 13: Standard deviation and relative standard deviation introduced due to the use of the Wastetool data, obtained from Equation 8.

\begin{tabular}{|l|c|c|c|}
\hline & $\mathrm{n}$ & $\mathrm{SD},[\mathrm{kg}$ gross $/ \mathrm{a}]$ & $\mathrm{RSD},[\%]$ \\
\hline Mono-P and or Mono-BC & 19 & 110,218 & $1.6 \%$ \\
\hline PD & 30 & 352,869 & $1.8 \%$ \\
\hline PMD & 30 & 670,132 & $1.8 \%$ \\
\hline
\end{tabular}

The use of the Wastetool data that has been entered by municipalities in the data field "plastic packages" as total collection responses for the PD and PMD collecting municipalities introduces errors in the calculations made in this report. For PD- and PMD-collecting municipalities this error was calculated to be $1.8 \%$ relative to collection response in Wastetool.

The impact of collection response uncertainty on the calculations for municipalities that separately collect beverage cartons (Mono-BC) is limited, since these municipalities weigh and register the beverage cartons separately. These municipalities enter this data in the data field "separate collected beverage cartons" of Wastetool and this is the data used in this study for these municipalities. However, since a few municipalities also subject their MSW to mechanical recovery, and add the sorted products from recovery to the separately collection amounts, the Wastetool data slightly overestimates this collection response.

The impact of this data uncertainty on the recovery system is from a different nature. To describe the recovery system we used the data from Wastetool from the data field "beverage cartons" as amounts of sorted beverage cartons that were produced on behalf of that municipality. That will not introduce a large error on itself. A much larger concern is the error that the categorisation of municipalities introduces on the calculations for recycling chain. Of roughly 10 to 20 municipalities from the provinces of Drenthe, Brabant and Limburg we assume that they not only operate a separate collection system, but also subject their MSW to mechanical recovery. In this study we do not exactly know which municipalities have such a combination system nor do we how the contributions from both subsystems should be split, so we categorised them as separate collection municipalities. This has as consequence that the gross responses for separate collection municipalities are slightly over-estimated (see previous part) and for the recovery system under-estimated. On the other hand, the amount of inhabitants that contribute to recovery system is under-estimated as well by this choice of categorisation. This uncertainty will propagate into a relative larger error for the net chain yield for the recovery system, since this parameter is derived from the sorted amounts of beverage cartons made from recovering municipalities (which we know with a relative small error) divided by the net potential for these municipalities (which we do not know precisely due to the uncertainty in the categorisation). 
In summary, the use of the Wastetool-data gives reasonable good response data for Mono-BC, PD and PMD collecting municipalities. This data also gives a good estimation of the amount of sorted products that are produced on behalf of recovering municipalities. The errors that were introduced by using the Wastetool-data were calculated and used in the further error calculations, see paragraphs 2.4.1-2.4.4.

In hindsight, one could argue based on figure 15, that the PMD response could better be estimated by taking the data field "plastic packages" and use that as the amount of plastic packages in the PMD mixture. One should then rely on the knowledge of the municipality regarding PMD composition and this would introduce an error.

\subsection{Recycling system on the edge}

The recycling system of beverage cartons in the Netherlands has developed since the pilot of 2013. The collection methods studied in the pilot have been implemented by most of the municipalities and currently roughly $93 \%$ of the Dutch population is connected to either a collection or a recovery option for beverage cartons. Simultaneously the net material chain yields have hardly developed, implying that the amounts collected, sorted and recycled have mostly increased over the years due to system expansion and not by system optimisation.

Large changes occurred between 2013 and 2017 at the sorting facilities, mostly on the contractual level. The gross sorting division improved since the pilot to $73 \pm 5 \%$, but did not attain the theoretical optimum of roughly $80 \%$ yet [Thoden van Velzen et al. 2014]. Simultaneously, the sorted beverage carton products now contain more residual wastes than during the pilot of 2013 . For the three recycling companies the sorted beverage carton feedstock from the Netherlands has developed into a quality-wise critical feedstock. Some have stopped temporarily recycling beverage cartons, since their products smelled and had to be incinerated. They also experienced strong odour formation from and infestation (especially flies) in the purchased feedstock, which resulted in complaints from neighbours of all three recycling facilities. One recycling facility was able to change its operations and process (just-in-time delivery of feedstock, direct processing of this feedstock, zero stock on the yard, increased purification of the circulating pulping water) and processed most of the sorted beverage cartons during 2016 and 2017. Another recycling facility has made several adaptations and will restart with processing Dutch beverage cartons from the end of November 2017 on. These experiences of recycling companies reveal that the recycling of Dutch beverage cartons is not simple and straightforward, but rather critical. The composition of this feedstock is such that companies are still able to make valuable products from the feedstock but with an increased effort. Therefore, it is a recycling system on the edge. Implying that when the composition of the feedstock would worsen in the near future (due to detrimental changes in packaging design, collection methods or sorting policies), it would be likely that recycling companies will no longer be able to produce valuable products from it. 


\section{Conclusions}

The collection and recycling chains for beverage cartons have matured since 2013. Whereas in 2013 only civilians in a few pilot-municipalities could contribute to the recycling of beverage cartons, in 2016 more than $93 \%$ of the population of the Netherlands was connected to separate collection and/or mechanical recovery systems for beverage cartons. Whereas the system grew rapidly by geographical expansion, the net material yields for collection, sorting and recycling all remained roughly similar as in 2013. Simultaneously, the quality of the sorted beverage carton product has declined since 2013. This feedstock now contains more residual waste than in 2013, which hampers subsequent recycling processes.

It is likely that the beverage cartons cross-contaminate other co-collected packages such as plastic packages and metal packages, but only after the collected material is pressed in a collection vehicle or during baling of sorting products. The cross-contamination can, however, not been proven from the data gathered in this project, since the quality of sorted products has also negatively been affected by two other simultaneously occurring factors: changed sorting policies and longer lead-times.

The most critical quality attribute of Dutch beverage cartons is the smell that is released upon recycling (pulping). This smell most likely originates from decaying product residues that are contained with the cartons and are freed during recycling. No evidence was found for a gradual decline in the mechanical quality of the paper fibres during the storage of beverage cartons in time (maximal 4 weeks at $40^{\circ} \mathrm{C}$ ). The paper fibres are obviously well-protected against microbial decay within the plastic films.

During 2016-2017, only one recycling facility was able to process this relatively highly contaminated feedstock continuously, the two other facilities had to reduce their intake of Dutch beverage cartons drastically. Nevertheless, from the end of November 2017 one of these recycling facilities has modified its equipment and is ready to engage fully in the recycling of Dutch beverage cartons. Quality-wise this recycling chain is balancing on the edge; it is still operational, but it is unlikely that they can deal with additional quality set-backs as observed in the past years.

\section{General recommendations}

In order to improve the quality of the sorted beverage carton products and to increase the level of compliance to the DKR 510 specification, the Framework treaty parties could consider measures which would raise the quality of the collected materials (mono-P, PD and PMD), such as: consumer campaigns, focussed quality inspections of mini-containers and interventions at drop-off container which collect too much residual waste (camera's, civil servants, mirrors). The Framework treaty parties could also consider to address the sorting companies and their sorting policies, which is strongly related to the organisation of the recycling chain and the contract with the sorting facilities. 
To alleviate the odour issues and hygiene issues connected with the collection, sorting and recycling of Dutch beverage cartons, the Framework treaty parties could consider organising a public campaign to promote civilians to rinse their cartons with cold water prior to collection.

To obtain more transparency in the collection methods applied by municipalities, the Framework treaty parties could consider to ask the national monitoring agency Nedvang, to systematically collect and archive information from the municipalities on the collection methods applied for each packaging material and to keep this information up to date. 


\section{References}

Fellner J, Aschenbrenner P, Cencic O \& Rechberger H (2011) Determination of the biogenic and fossil organic matter content of refuse-derived fuels based on elementary analyses. Fuel 90 (11): 3164-3171.

Y. Leenaars, E. Boer, "Samenstelling ingezameld kunststof/PMD verpakkingen -het effect van inzamelsystemen" Eureco en WUR rapportage, 26 June 2017, Learning Centre Kunststofverpakkingsafval, Utrecht.

S. Mellema, "Processing beverage cartons into Renewable Chemicals and Recovered Aluminium by low temperature Thermolysis based on the FUENIX ECOGY® Technology" Conference presentation at EAP Rotterdam 2017 September $22^{\text {nd }}$.

E.U. Thoden van Velzen, M.T. Brouwer, E. Keijsers, prof. dr. Th. Pretz, A. Feil, M. Jansen Pilot beverage cartons 2013, extended technical report, FBR report 1440, Wageningen December 5th 2013.

E.U. Thoden van Velzen, M.T. Brouwer, Th. Pretz, M. Jansen, “Terugslageffecten bij gecombineerde inzameling van kunststof en drankenkartons" FBR rapport nr 1471, Wageningen April 7th 2014.

Vienna, University (2017) Stan-website: www.stan2web.net (accessed January 23rd 2017). 


\section{Acknowledgements}

Peter Blok and Michiel Kort and all the representatives of the three framework treaty partners for trusting us to perform this research.

We thank Eric Boer for his help with the statistics and error propagation laws.

Michiel Kort and Leontine Kiés van Westerik are acknowledged for their suggestions to improve the readability of paragraph 4.1.

Mark Tegelaar and Hendrik-Jan Graat of Nedvang for assisting with the Wastetool-data and offering access to the pictures of the sorted products of the quality controls in 2016.

We are grateful that the recyclers of beverage cartons were willing to share their experiences with us. Some were very easy to approach and helped us greatly. Others were more difficult to engage in this research, but we are nevertheless grateful for the time they took to answer us.

Civil servants and employees of collection companies are especially acknowledged for helping us to attain samples of collected material from the various municipalities. Although we noticed that a few municipalities were unwilling to co-operate with us, this was more than compensated by the pleasant and practical co-operations by so many. 


\section{List of abbreviations}

\begin{tabular}{|l|l|}
\hline Al & Aluminium \\
\hline Av & Average \\
\hline BC & Beverage cartons \\
\hline CR & Collection response \\
\hline CO & Combined collection system of kerbside and drop-off \\
\hline COM & Contributions of other materials \\
\hline DO & Drop-off \\
\hline DKR & Deutsche Gesellschaft für Kreislaufwirtschaft und Rohstoffe. \\
\hline DRQ & Data reconciliation quality indicator \\
\hline HRB & High-rise buildings \\
\hline KS & Kerbside \\
\hline MDC & Moisture and dirt content \\
\hline MIX & Sorting product "Mixed plastics" \\
\hline MSW & Mixed municipal solid waste \\
\hline NP & NON-PAYT, a municipality without a 'pay as you throw' scheme \\
\hline PA & PAYT, Pay as you throw \\
\hline PAYT & Pay as you throw \\
\hline PD & Co-collection system of plastic packages and beverage cartons \\
\hline PE & Polyethylene \\
\hline PET & Polyethylene terephthalate \\
\hline PMD & Co-collection system of plastic packages, metal packages and beverage cartons \\
\hline PP & Polypropylene \\
\hline P\&B & Paper and board \\
\hline Po / Pot & Potential \\
\hline SCT & Strip compression test \\
\hline SP & Sorted product \\
\hline UHT & Ultra high temperature (sterilised beverage products) \\
\hline WOR & Washed off residues \\
\hline
\end{tabular}




\section{Appendices}

Appendix A: Sorting analysis results for all samples

Appendix B: Input data for STAN

Appendix C: Material flow schemes

Appendix D: Paper fibre fractionation results

Appendix E: Categorisation of municipalities 


\section{Appendix A: All sorting results per sample}

Co-collection with plastic and metal (PMD)

\begin{tabular}{|c|c|c|c|c|c|}
\hline \multirow[b]{2}{*}{ Category of beverage cartons } & \multicolumn{2}{|l|}{ Municipality: } & \multicolumn{3}{|c|}{ Sampling date: } \\
\hline & $\begin{array}{c}\text { Gross weight in the sample } \\
{[\mathrm{g}]}\end{array}$ & $\begin{array}{c}\text { Gross material content } \\
{[\%]}\end{array}$ & $\begin{array}{c}\text { Total moisture and dirt } \\
{[\%]}\end{array}$ & $\begin{array}{c}\text { Outside } \\
{[\%]}\end{array}$ & $\begin{array}{c}\text { Inside } \\
{[\%]}\end{array}$ \\
\hline Milk cartons $\geq 1 \mathrm{~L}$ & 2281 & $3.7 \%$ & $27.9 \%$ & $1.4 \%$ & $26.5 \%$ \\
\hline Milk cartons $<1 \mathrm{~L}$ & 65 & $0.1 \%$ & $16.9 \%$ & $0.0 \%$ & $16.9 \%$ \\
\hline UHT milk cartons $\geq 1 \mathrm{~L}$ & 544 & $0.9 \%$ & $24.7 \%$ & $0.9 \%$ & $23.8 \%$ \\
\hline UHT milk cartons $<1 \mathrm{~L}$ & 20 & $0.0 \%$ & $19.2 \%$ & $7.7 \%$ & $11.5 \%$ \\
\hline Yoghurt \& dessert cartons $\geq 1 \mathrm{~L}$ & 3187 & $5.2 \%$ & $42.1 \%$ & $0.4 \%$ & $41.7 \%$ \\
\hline Yoghurt \& dessert cartons $<1 \mathrm{~L}$ & 76 & $0.1 \%$ & $38.0 \%$ & $11.4 \%$ & $26.6 \%$ \\
\hline Juice cartons $\geq 1 \mathrm{~L}$ & 2230 & $3.7 \%$ & $17.3 \%$ & $0.3 \%$ & $16.9 \%$ \\
\hline Juice cartons $<1 \mathrm{~L}$ & 141 & $0.2 \%$ & $23.7 \%$ & $1.4 \%$ & $22.3 \%$ \\
\hline Cartons with fresh mixes of juice \& diary $\geq 1 \mathrm{~L}$ & 762 & $1.3 \%$ & $30.4 \%$ & $2.0 \%$ & $28.4 \%$ \\
\hline Cartons with fresh mixes of juice \& diary $<1 \mathrm{~L}$ & 0 & $0.0 \%$ & $0.0 \%$ & $0.0 \%$ & $0.0 \%$ \\
\hline Cartons with UHT mixes of juice \& diary $\geq 1 \mathrm{~L}$ & 116 & $0.2 \%$ & $18.6 \%$ & $0.9 \%$ & $17.7 \%$ \\
\hline Cartons with UHT mixes of juice \& diary $<1 \mathrm{~L}$ & 74 & $0.1 \%$ & $18.7 \%$ & $0.0 \%$ & $18.7 \%$ \\
\hline Residual cartons $\geq 1 \mathrm{~L}$ & 81 & $0.1 \%$ & $21.7 \%$ & $2.4 \%$ & $19.3 \%$ \\
\hline Residual cartons $<1 \mathrm{~L}$ & 300 & $0.5 \%$ & $30.0 \%$ & $1.3 \%$ & $28.6 \%$ \\
\hline Plastics & 37683 & $61.9 \%$ & \multirow{3}{*}{\multicolumn{2}{|c|}{$\begin{array}{r}\text { Weight-averaged total MAD: } \\
\text { Weight-averaged outside MAD: } \\
\text { Weight-averaged inside MAD: }\end{array}$}} & $29.9 \%$ \\
\hline Paper and board & 2846 & $4.7 \%$ & & & $0.9 \%$ \\
\hline Organic waste and indefinable waste & 3792 & $6.2 \%$ & & & $29.0 \%$ \\
\hline Textile & 362 & $0.6 \%$ & \multirow{4}{*}{\multicolumn{2}{|c|}{ Municipality characteristics }} & \\
\hline Ferrous metal & 4844 & $8.0 \%$ & & & \\
\hline Non-ferrous metal & 1436 & $2.4 \%$ & & & \\
\hline Glass & 78 & $0.1 \%$ & & & \\
\hline \multirow{3}{*}{ Agglomerate } & 0 & $0.0 \%$ & High-rise buildin & $<50 \%$ & \\
\hline & 60918 & $100 \%$ & Collection portfo & PMD & \\
\hline & & & $P A$ & Yes & \\
\hline \multicolumn{2}{|l|}{ Plastic - moisture and dirt content } & {$[\%]$} & Collection meth & Kerbside & \\
\hline \multirow{2}{*}{\multicolumn{2}{|c|}{$\begin{array}{l}\text { PET beverage bottles } \\
\text { PE non-beverage bottles }\end{array}$}} & $8.7 \%$ & & & \\
\hline \multirow{2}{*}{\multicolumn{2}{|c|}{$\begin{array}{l}\text { PE non-beverage bottles } \\
\text { PP rigid and thermoformed packaging }\end{array}$}} & $18.7 \%$ & Sample density $[\mathrm{kg} / \mathrm{m}$ & 30.5 & \\
\hline & & $11.4 \%$ & & & \\
\hline \multirow{2}{*}{\multicolumn{2}{|c|}{$\begin{array}{l}\mathrm{PE} \text { foil }>A 4 \\
P E T \text { rigid and thermoformed packaging }\end{array}$}} & $18.8 \%$ & & & \\
\hline & & $13.0 \%$ & & & \\
\hline & Weight-averaged MAD Plastic & $13.8 \%$ & & & \\
\hline
\end{tabular}

Notes 


\begin{tabular}{|c|c|c|c|c|c|}
\hline Category of beverage cartons & $\begin{array}{c}\text { Gross weight in the sample } \\
{[\mathrm{g}]}\end{array}$ & $\begin{array}{c}\text { Gross material content } \\
{[\%]}\end{array}$ & $\begin{array}{c}\text { Total moisture and dirt } \\
{[\%]}\end{array}$ & $\begin{array}{c}\text { Outside } \\
{[\%]}\end{array}$ & $\begin{array}{c}\text { Inside } \\
{[\%]}\end{array}$ \\
\hline Milk cartons $\geq 1 \mathrm{~L}$ & 436 & $1.6 \%$ & $25.8 \%$ & $1.0 \%$ & $24.7 \%$ \\
\hline Milk cartons $<1 \mathrm{~L}$ & 73 & $0.3 \%$ & $37.7 \%$ & $4.4 \%$ & $33.3 \%$ \\
\hline UHT milk cartons $\geq 1 \mathrm{~L}$ & 0 & $0.0 \%$ & $0.0 \%$ & $0.0 \%$ & $0.0 \%$ \\
\hline UHT milk cartons $<1 \mathrm{~L}$ & 116 & $0.4 \%$ & $37.7 \%$ & $4.4 \%$ & $33.3 \%$ \\
\hline Yoghurt \& dessert cartons $\geq 1 \mathrm{~L}$ & 0 & $0.0 \%$ & $0.0 \%$ & $0.0 \%$ & $0.0 \%$ \\
\hline Yoghurt \& dessert cartons $<1 \mathrm{~L}$ & 37 & $0.1 \%$ & $48.6 \%$ & $5.4 \%$ & $43.2 \%$ \\
\hline Juice cartons $\geq 1 \mathrm{~L}$ & 522 & $1.9 \%$ & $26.3 \%$ & $1.5 \%$ & $24.8 \%$ \\
\hline Juice cartons $<1 \mathrm{~L}$ & 299 & $1.1 \%$ & $21.4 \%$ & $3.6 \%$ & $17.9 \%$ \\
\hline Cartons with fresh mixes of juice \& diary $\geq 1 \mathrm{~L}$ & 75 & $0.3 \%$ & $27.0 \%$ & $1.4 \%$ & $25.7 \%$ \\
\hline Cartons with fresh mixes of juice \& diary $<1 \mathrm{~L}$ & 0 & $0.0 \%$ & $0.0 \%$ & $0.0 \%$ & $0.0 \%$ \\
\hline Cartons with UHT mixes of juice \& diary $\geq 1 \mathrm{~L}$ & 0 & $0.0 \%$ & $0.0 \%$ & $0.0 \%$ & $0.0 \%$ \\
\hline Cartons with UHT mixes of juice \& diary $<1 \mathrm{~L}$ & 59 & $0.2 \%$ & $26.7 \%$ & $1.7 \%$ & $25.0 \%$ \\
\hline Residual cartons $\geq 1 \mathrm{~L}$ & 43 & $0.2 \%$ & $34.1 \%$ & $4.9 \%$ & $29.3 \%$ \\
\hline Residual cartons $<1 \mathrm{~L}$ & 64 & $0.2 \%$ & $29.7 \%$ & $1.6 \%$ & $28.1 \%$ \\
\hline Plastics & 24499 & $88.1 \%$ & \multirow{3}{*}{\multicolumn{2}{|c|}{$\begin{array}{r}\text { Weight-averaged total MAD: } \\
\text { Weight-averaged outside MAD: } \\
\text { Weight-averaged inside MAD: }\end{array}$}} & $27.4 \%$ \\
\hline Paper and board & 743 & $2.7 \%$ & & & $2.2 \%$ \\
\hline Organic waste and indefinable waste & 258 & $0.9 \%$ & & & $25.2 \%$ \\
\hline Textile & 3 & $0.0 \%$ & \multirow{4}{*}{\multicolumn{2}{|c|}{ Municipality characteristics }} & \\
\hline Ferrous metal & 370 & $1.3 \%$ & & & \\
\hline Non-ferrous metal & 205 & $0.7 \%$ & & & \\
\hline Glass & 0 & $0.0 \%$ & & & \\
\hline Agglomerate & 0 & $0.0 \%$ & \multirow{2}{*}{$\begin{array}{l}\text { High-rise building } \\
\text { Collection portfoli }\end{array}$} & $<50 \%$ & \\
\hline Total & 27802 & $100 \%$ & & PMD & \\
\hline & & & \multirow{3}{*}{$\begin{array}{r}P A Y \\
\text { Collection metho }\end{array}$} & No & \\
\hline \multicolumn{2}{|l|}{ Plastic - moisture and dirt content } & {$[\%]$} & & Kerbside & \\
\hline PET beverage bottles & & $6.3 \%$ & & \multirow{5}{*}{30.9} & \\
\hline PE non-beverage bottles & & $22.5 \%$ & \multirow[t]{5}{*}{ Sample density $[\mathrm{kg} / \mathrm{m}$} & & \\
\hline PP rigid and thermoformed packaging & & $2.5 \%$ & & & \\
\hline$P E$ foil $>A 4$ & & $10.0 \%$ & & & \\
\hline \multirow[t]{2}{*}{ PET rigid and thermoformed packaging } & & $3.1 \%$ & & & \\
\hline & Weight-averaged MAD Plastic & $8.0 \%$ & & & \\
\hline Notes & $\begin{array}{l}\text { This was a small sample, additio } \\
\text { sample }\end{array}$ & ere was one bag full & nich alone & $\mathrm{cca} 2$ & \\
\hline
\end{tabular}




\begin{tabular}{|c|c|c|c|c|c|}
\hline \multirow[b]{2}{*}{ Category of beverage cartons } & \multicolumn{2}{|l|}{ Municipality: } & Sampling date: & \multicolumn{2}{|c|}{29.6 .2017} \\
\hline & $\begin{array}{c}\text { Gross weight in the sample } \\
{[\mathrm{g}]}\end{array}$ & $\begin{array}{c}\text { Gross material content } \\
{[\%]}\end{array}$ & $\begin{array}{c}\text { Total moisture and dirt } \\
{[\%]}\end{array}$ & $\begin{array}{c}\text { Outside } \\
{[\%]}\end{array}$ & $\begin{array}{c}\text { Inside } \\
{[\%]}\end{array}$ \\
\hline Milk cartons $\geq 1 \mathrm{~L}$ & 2757 & $5.6 \%$ & $40.4 \%$ & $0.2 \%$ & $40.2 \%$ \\
\hline Milk cartons $<1 \mathrm{~L}$ & 249 & $0.5 \%$ & $22.5 \%$ & $0.4 \%$ & $22.1 \%$ \\
\hline UHT milk cartons $\geq 1 \mathrm{~L}$ & 510 & $1.0 \%$ & $25.5 \%$ & $0.3 \%$ & $25.3 \%$ \\
\hline UHT milk cartons < $1 \mathrm{~L}$ & 26 & $0.1 \%$ & $28.0 \%$ & $0.0 \%$ & $28.0 \%$ \\
\hline Yoghurt \& dessert cartons $\geq 1 \mathrm{~L}$ & 2329 & $4.8 \%$ & $51.8 \%$ & $0.3 \%$ & $51.4 \%$ \\
\hline Yoghurt \& dessert cartons < $1 \mathrm{~L}$ & 790 & $1.6 \%$ & $77.1 \%$ & $0.1 \%$ & $77.0 \%$ \\
\hline Juice cartons $\geq 1 \mathrm{~L}$ & 990 & $2.0 \%$ & $24.0 \%$ & $0.5 \%$ & $23.4 \%$ \\
\hline Juice cartons $<1 \mathrm{~L}$ & 125 & $0.3 \%$ & $18.7 \%$ & $1.9 \%$ & $16.8 \%$ \\
\hline Cartons with fresh mixes of juice $\&$ diary $\geq 1 \mathrm{~L}$ & 1098 & $2.2 \%$ & $39.8 \%$ & $0.2 \%$ & $39.7 \%$ \\
\hline Cartons with fresh mixes of juice \& diary $<1 \mathrm{~L}$ & 58 & $0.1 \%$ & $36.2 \%$ & $1.7 \%$ & $34.5 \%$ \\
\hline Cartons with UHT mixes of juice \& diary $\geq 1 \mathrm{~L}$ & 42 & $0.1 \%$ & $30.2 \%$ & $2.3 \%$ & $27.9 \%$ \\
\hline Cartons with UHT mixes of juice \& diary < $1 \mathrm{~L}$ & 34 & $0.1 \%$ & $48.6 \%$ & $0.0 \%$ & $48.6 \%$ \\
\hline Residual cartons $\geq 1 \mathrm{~L}$ & 196 & $0.4 \%$ & $20.4 \%$ & $0.5 \%$ & $19.9 \%$ \\
\hline Residual cartons $<1 \mathrm{~L}$ & 72 & $0.1 \%$ & $40.8 \%$ & $1.4 \%$ & $39.4 \%$ \\
\hline Plastics & 34852 & $71.3 \%$ & \multirow{3}{*}{\multicolumn{2}{|c|}{$\begin{array}{r}\text { Weight-averaged total MAD: } \\
\text { Weight-averaged outside MAD: } \\
\text { Weight-averaged inside MAD: }\end{array}$}} & $42.5 \%$ \\
\hline Paper and board & 194 & $0.4 \%$ & & & $0.3 \%$ \\
\hline Organic waste and indefinable waste & 967 & $2.0 \%$ & & & $42.2 \%$ \\
\hline Textile & 32 & $0.1 \%$ & \multirow{4}{*}{\multicolumn{2}{|c|}{ Municipality characteristics }} & \\
\hline Ferrous metal & 2336 & $4.8 \%$ & & & \\
\hline Non-ferrous metal & 1236 & $2.5 \%$ & & & \\
\hline Glass & 0 & $0.0 \%$ & & & \\
\hline Agglomerate & 0 & $0.0 \%$ & \multirow{2}{*}{$\begin{array}{l}\text { High-rise buildings: } \\
\text { Collection portfolio: }\end{array}$} & \multirow{2}{*}{$\begin{array}{l}<50 \% \\
\text { PMD }\end{array}$} & \\
\hline Total & 48893 & $100 \%$ & & & \\
\hline & & & \multirow{8}{*}{ Sample density $[\mathrm{kg} / \mathrm{m} 3]$ : } & No & \\
\hline Plastic - moisture and dirt content & & {$[\%]$} & & \multirow{2}{*}{ Kerbside } & \\
\hline PET beverage bottles & & $16.7 \%$ & & & \\
\hline PE non-beverage bottles & & $28.2 \%$ & & \multirow[t]{4}{*}{24.4} & \\
\hline PP rigid and thermoformed packaging & & $4.7 \%$ & & & \\
\hline$P E$ foil >A4 & & $1.1 \%$ & & & \\
\hline PET rigid and thermoformed packaging & & $1.1 \%$ & & & \\
\hline & Weight-averaged MAD Plastic & $7.9 \%$ & & & \\
\hline Notes & & & & & \\
\hline
\end{tabular}


Municipality:

Sampling date:

29.6.2017

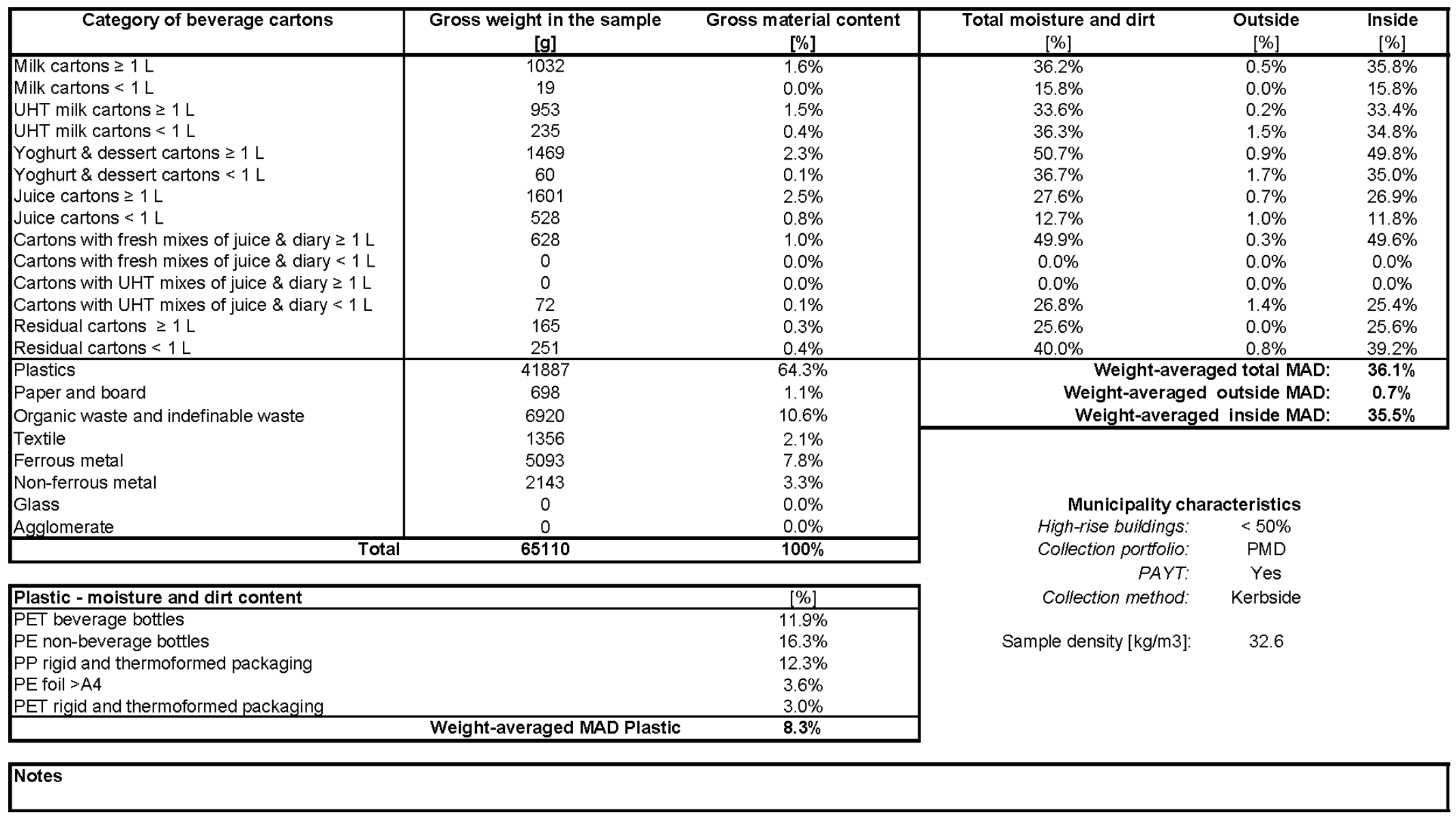




\begin{tabular}{|c|c|c|c|c|c|}
\hline \multirow[b]{2}{*}{ Category of beverage cartons } & \multicolumn{2}{|l|}{ Municipality: } & Sampling date: & \multicolumn{2}{|c|}{27.6 .2017} \\
\hline & $\begin{array}{c}\text { Gross weight in the sample } \\
{[\mathrm{g}]}\end{array}$ & $\begin{array}{c}\text { Gross material content } \\
{[\%]}\end{array}$ & $\begin{array}{l}\text { Total moisture and dirt } \\
{[\%]}\end{array}$ & $\begin{array}{c}\text { Outside } \\
\text { [\%] }\end{array}$ & $\begin{array}{c}\text { Inside } \\
{[\%]}\end{array}$ \\
\hline Milk cartons $\geq 1 \mathrm{~L}$ & 886 & $1.1 \%$ & $16.8 \%$ & $0.0 \%$ & $16.8 \%$ \\
\hline Milk cartons $<1 \mathrm{~L}$ & 0 & $0.0 \%$ & $0.0 \%$ & $0.0 \%$ & $0.0 \%$ \\
\hline UHT milk cartons $\geq 1 \mathrm{~L}$ & 1768 & $2.2 \%$ & $22.8 \%$ & $0.0 \%$ & $22.8 \%$ \\
\hline UHT milk cartons $<1 \mathrm{~L}$ & 106 & $0.1 \%$ & $35.8 \%$ & $1.9 \%$ & $34.0 \%$ \\
\hline Yoghurt \& dessert cartons $\geq 1 \mathrm{~L}$ & 715 & $0.9 \%$ & $52.2 \%$ & $0.5 \%$ & $51.6 \%$ \\
\hline Yoghurt \& dessert cartons $<1 \mathrm{~L}$ & 148 & $0.2 \%$ & $47.6 \%$ & $2.7 \%$ & $44.9 \%$ \\
\hline Juice cartons $\geq 1 \mathrm{~L}$ & 1637 & $2.0 \%$ & $15.8 \%$ & $0.4 \%$ & $15.4 \%$ \\
\hline Juice cartons $<1 \mathrm{~L}$ & 49 & $0.1 \%$ & $16.3 \%$ & $2.0 \%$ & $14.3 \%$ \\
\hline Cartons with fresh mixes of juice \& diary $\geq 1 \mathrm{~L}$ & 457 & $0.6 \%$ & $35.3 \%$ & $1.1 \%$ & $34.2 \%$ \\
\hline Cartons with fresh mixes of juice \& diary $<1 \mathrm{~L}$ & 109 & $0.1 \%$ & $42.7 \%$ & $0.9 \%$ & $41.8 \%$ \\
\hline Cartons with UHT mixes of juice \& diary $\geq 1 \mathrm{~L}$ & 76 & $0.1 \%$ & $24.0 \%$ & $1.3 \%$ & $22.7 \%$ \\
\hline Cartons with UHT mixes of juice \& diary $<1 \mathrm{~L}$ & 10 & $0.0 \%$ & $20.0 \%$ & $0.0 \%$ & $20.0 \%$ \\
\hline Residual cartons $\geq 1 \mathrm{~L}$ & 759 & $0.9 \%$ & $18.1 \%$ & $0.2 \%$ & $17.9 \%$ \\
\hline Residual cartons $<1 \mathrm{~L}$ & 337 & $0.4 \%$ & $28.2 \%$ & $0.6 \%$ & $27.6 \%$ \\
\hline Plastics & 60400 & $74.1 \%$ & \multirow{3}{*}{\multicolumn{2}{|c|}{$\begin{array}{r}\text { Weight-averaged total MAD: } \\
\text { Weight-averaged outside MAD: } \\
\text { Weight-averaged inside MAD: }\end{array}$}} & $24.9 \%$ \\
\hline Paper and board & 1199 & $1.5 \%$ & & & $0.4 \%$ \\
\hline Organic waste and indefinable waste & 4120 & $5.1 \%$ & & & $24.5 \%$ \\
\hline Textile & 415 & $0.5 \%$ & \multirow{4}{*}{\multicolumn{2}{|c|}{ Municipality characteristics }} & \\
\hline Ferrous metal & 5669 & $7.0 \%$ & & & \\
\hline Non-ferrous metal & 1223 & $1.5 \%$ & & & \\
\hline Glass & 495 & $0.6 \%$ & & & \\
\hline \multirow{3}{*}{ Agglomerate } & 903 & $1.1 \%$ & High-rise buildings: & $<50 \%$ & \\
\hline & 81481 & $100 \%$ & Collection portfolio: & PMD & \\
\hline & & & PAYT: & Yes & \\
\hline Plastic - moisture and dirt content & & {$[\%]$} & Collection method: & Drop off & \\
\hline PET beverage bottles & & $18.4 \%$ & & & \\
\hline PE non-beverage bottles & & $25.5 \%$ & Sample density $[\mathrm{kg} / \mathrm{m} 3]$ : & 54.3 & \\
\hline PP rigid and thermoformed packaging & & $1.9 \%$ & & & \\
\hline$P E$ foil $>A 4$ & & $5.1 \%$ & & & \\
\hline PET rigid and thermoformed packaging & & $0.8 \%$ & & & \\
\hline & Weight-averaged MAD Plastic & $7.7 \%$ & & & \\
\hline Notes & & & & & \\
\hline
\end{tabular}




\begin{tabular}{|c|c|c|c|c|c|}
\hline \multirow[b]{2}{*}{ Category of beverage cartons } & \multicolumn{2}{|l|}{ Municipality: } & Sampling date: & \multicolumn{2}{|c|}{27.6 .2017} \\
\hline & $\begin{array}{c}\text { Gross weight in the sample } \\
{[\mathrm{g}]}\end{array}$ & $\begin{array}{c}\text { Gross material content } \\
{[\%]}\end{array}$ & $\begin{array}{l}\text { Total moisture and dirt } \\
{[\%]}\end{array}$ & $\begin{array}{c}\text { Outside } \\
\text { [\%] }\end{array}$ & $\begin{array}{c}\text { Inside } \\
{[\%]}\end{array}$ \\
\hline Milk cartons $\geq 1 \mathrm{~L}$ & 1647 & $3.2 \%$ & $25.9 \%$ & $0.3 \%$ & $25.6 \%$ \\
\hline Milk cartons $<1 \mathrm{~L}$ & 42 & $0.1 \%$ & $14.0 \%$ & $0.0 \%$ & $14.0 \%$ \\
\hline UHT milk cartons $\geq 1 \mathrm{~L}$ & 230 & $0.4 \%$ & $0.0 \%$ & $0.0 \%$ & $0.0 \%$ \\
\hline UHT milk cartons $<1 \mathrm{~L}$ & 0 & $0.0 \%$ & $25.8 \%$ & $0.0 \%$ & $25.8 \%$ \\
\hline Yoghurt \& dessert cartons $\geq 1 \mathrm{~L}$ & 2184 & $4.2 \%$ & $54.8 \%$ & $0.9 \%$ & $54.0 \%$ \\
\hline Yoghurt \& dessert cartons $<1 \mathrm{~L}$ & 218 & $0.4 \%$ & $68.3 \%$ & $0.5 \%$ & $67.9 \%$ \\
\hline Juice cartons $\geq 1 \mathrm{~L}$ & 2070 & $4.0 \%$ & $27.1 \%$ & $0.4 \%$ & $26.7 \%$ \\
\hline Juice cartons $<1 \mathrm{~L}$ & 99 & $0.2 \%$ & $20.2 \%$ & $1.0 \%$ & $19.2 \%$ \\
\hline Cartons with fresh mixes of juice \& diary $\geq 1 \mathrm{~L}$ & 727 & $1.4 \%$ & $60.3 \%$ & $9.4 \%$ & $51.0 \%$ \\
\hline Cartons with fresh mixes of juice \& diary $<1 \mathrm{~L}$ & 41 & $0.1 \%$ & $62.5 \%$ & $20.0 \%$ & $42.5 \%$ \\
\hline Cartons with UHT mixes of juice \& diary $\geq 1 \mathrm{~L}$ & 0 & $0.0 \%$ & $0.0 \%$ & $0.0 \%$ & $0.0 \%$ \\
\hline Cartons with UHT mixes of juice \& diary $<1 \mathrm{~L}$ & 0 & $0.0 \%$ & $0.0 \%$ & $0.0 \%$ & $0.0 \%$ \\
\hline Residual cartons $\geq 1 \mathrm{~L}$ & 0 & $0.0 \%$ & $0.0 \%$ & $0.0 \%$ & $0.0 \%$ \\
\hline Residual cartons $<1 \mathrm{~L}$ & 44 & $0.1 \%$ & $25.6 \%$ & $0.0 \%$ & $25.6 \%$ \\
\hline Plastics & 32321 & $62.0 \%$ & \multirow{3}{*}{\multicolumn{2}{|c|}{$\begin{array}{r}\text { Weight-averaged total MAD: } \\
\text { Weight-averaged outside MAD: } \\
\text { Weight-averaged inside MAD: }\end{array}$}} & $38.8 \%$ \\
\hline Paper and board & 961 & $1.8 \%$ & & & $1.5 \%$ \\
\hline Organic waste and indefinable waste & 4356 & $8.3 \%$ & & & $37.3 \%$ \\
\hline Textile & 2337 & $4.5 \%$ & \multirow{4}{*}{\multicolumn{2}{|c|}{ Municipality characteristics }} & \\
\hline Ferrous metal & 2979 & $5.7 \%$ & & & \\
\hline Non-ferrous metal & 1025 & $2.0 \%$ & & & \\
\hline Glass & 888 & $1.7 \%$ & & & \\
\hline \multirow{3}{*}{ Agglomerate } & 0 & $0.0 \%$ & High-rise buildings: & $<50 \%$ & \\
\hline & 52169 & $100 \%$ & Collection porffolio: & PMD & \\
\hline & & & PAYT: & Yes & \\
\hline Plastic - moisture and dirt content & & {$[\%]$} & Collection method: & Kerbside & \\
\hline PET beverage bottles & & $7.9 \%$ & & & \\
\hline PE non-beverage bottles & & $22.9 \%$ & Sample density $[\mathrm{kg} / \mathrm{m} 3]$ : & 26.1 & \\
\hline PP rigid and thermoformed packaging & & $3.5 \%$ & & & \\
\hline$P E$ foil >A4 & & $0.0 \%$ & & & \\
\hline PET rigid and thermoformed packaging & & $3.4 \%$ & & & \\
\hline & Weight-averaged MAD Plastic & $6.4 \%$ & & & \\
\hline tes & & & & & \\
\hline
\end{tabular}




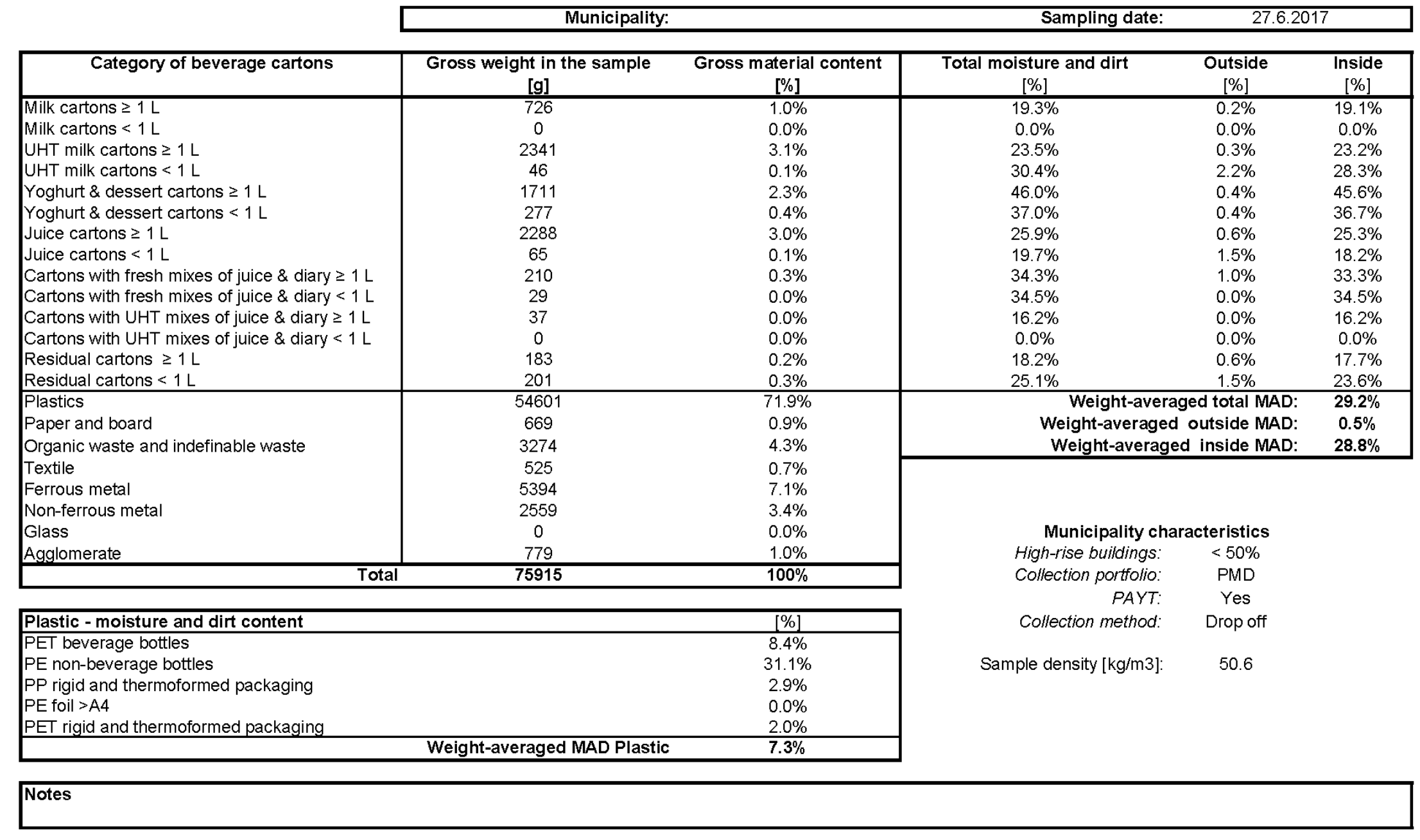




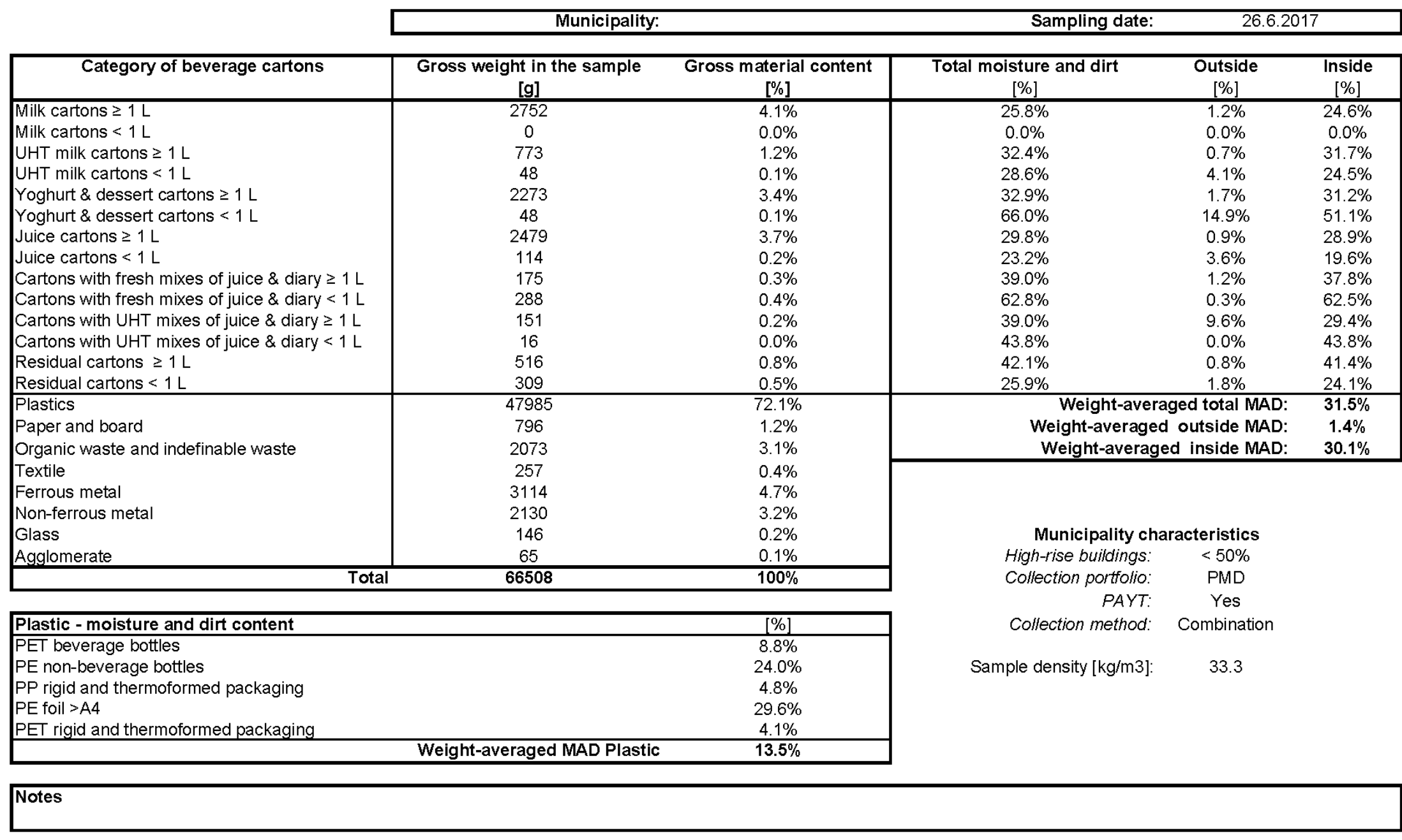




\begin{tabular}{|c|c|c|c|c|c|}
\hline \multirow[b]{2}{*}{ Category of beverage cartons } & \multicolumn{2}{|l|}{ Municipality: } & \multicolumn{3}{|c|}{ Sampling date: } \\
\hline & $\begin{array}{l}\text { Gross weight in the sample } \\
{[\mathrm{g}]}\end{array}$ & $\begin{array}{c}\text { Gross material content } \\
{[\%]}\end{array}$ & $\begin{array}{c}\text { Total moisture and dirt } \\
{[\%]}\end{array}$ & $\begin{array}{c}\text { Outside } \\
\text { [\%] }\end{array}$ & $\begin{array}{c}\text { Inside } \\
{[\%]}\end{array}$ \\
\hline Milk cartons $\geq 1 \mathrm{~L}$ & 1530 & $2.2 \%$ & $31.5 \%$ & $0.5 \%$ & $31.1 \%$ \\
\hline Milk cartons $<1 \mathrm{~L}$ & 0 & $0.0 \%$ & $0.0 \%$ & $0.0 \%$ & $0.0 \%$ \\
\hline UHT milk cartons $\geq 1 \mathrm{~L}$ & 503 & $0.7 \%$ & $30.3 \%$ & $0.2 \%$ & $30.1 \%$ \\
\hline UHT milk cartons $<1 \mathrm{~L}$ & 39 & $0.1 \%$ & $17.5 \%$ & $2.5 \%$ & $15.0 \%$ \\
\hline Yoghurt \& dessert cartons $\geq 1 \mathrm{~L}$ & 1244 & $1.8 \%$ & $73.4 \%$ & $0.0 \%$ & $73.4 \%$ \\
\hline Yoghurt \& dessert cartons $<1 \mathrm{~L}$ & 350 & $0.5 \%$ & $60.5 \%$ & $0.9 \%$ & $59.6 \%$ \\
\hline Juice cartons $\geq 1 \mathrm{~L}$ & 709 & $1.0 \%$ & $34.5 \%$ & $0.0 \%$ & $34.5 \%$ \\
\hline Juice cartons $<1 \mathrm{~L}$ & 163 & $0.2 \%$ & $17.4 \%$ & $0.0 \%$ & $17.4 \%$ \\
\hline Cartons with fresh mixes of juice \& diary $\geq 1 \mathrm{~L}$ & 397 & $0.6 \%$ & $55.3 \%$ & $0.3 \%$ & $55.1 \%$ \\
\hline Cartons with fresh mixes of juice \& diary $<1 \mathrm{~L}$ & 88 & $0.1 \%$ & $50.6 \%$ & $0.0 \%$ & $50.6 \%$ \\
\hline Cartons with UHT mixes of juice \& diary $\geq 1 \mathrm{~L}$ & 158 & $0.2 \%$ & $43.6 \%$ & $0.0 \%$ & $43.6 \%$ \\
\hline Cartons with UHT mixes of juice \& diary $<1 \mathrm{~L}$ & 0 & $0.0 \%$ & $0.0 \%$ & $0.0 \%$ & $0.0 \%$ \\
\hline Residual cartons $\geq 1 \mathrm{~L}$ & 1784 & $2.6 \%$ & $27.6 \%$ & $0.0 \%$ & $27.6 \%$ \\
\hline Residual cartons $<1 \mathrm{~L}$ & 348 & $0.5 \%$ & $36.7 \%$ & $0.9 \%$ & $35.8 \%$ \\
\hline Plastics & 35236 & $50.5 \%$ & \multirow{3}{*}{\multicolumn{2}{|c|}{$\begin{array}{r}\text { Weight-averaged total MAD: } \\
\text { Weight-averaged outside MAD: } \\
\text { Weight-averaged inside MAD: }\end{array}$}} & $40.9 \%$ \\
\hline Paper and board & 6989 & $10.0 \%$ & & & $0.2 \%$ \\
\hline Organic waste and indefinable waste & 10200 & $14.6 \%$ & & & $40.7 \%$ \\
\hline Textile & 2940 & $4.2 \%$ & \multirow{4}{*}{\multicolumn{2}{|c|}{ Municipality characteristics }} & \\
\hline Ferrous metal & 3699 & $5.3 \%$ & & & \\
\hline Non-ferrous metal & 2103 & $3.0 \%$ & & & \\
\hline Glass & 1326 & $1.9 \%$ & & & \\
\hline \multirow{3}{*}{ Agglomerate } & 0 & $0.0 \%$ & High-rise buildin & $\geq 50 \%$ & \\
\hline & 69806 & $100 \%$ & Collection portfo & PMD & \\
\hline & & & $P A$ & No & \\
\hline \multicolumn{2}{|l|}{ Plastic - moisture and dirt content } & {$[\%]$} & Collection meth & Drop off & \\
\hline \multirow{5}{*}{$\begin{array}{l}\text { PET beverage bottles } \\
\text { PE non-beverage bottles } \\
\text { PP rigid and thermoformed packaging } \\
\text { PE foil >A4 } \\
\text { PET rigid and thermoformed packaging }\end{array}$} & & $12.8 \%$ & & & \\
\hline & & $24.7 \%$ & Sample density $[\mathrm{kg} / \mathrm{r}$ & 34.9 & \\
\hline & & $12.6 \%$ & & & \\
\hline & & $3.6 \%$ & & & \\
\hline & & $11.3 \%$ & & & \\
\hline & Weight-averaged MAD Plastic & $12.4 \%$ & & & \\
\hline Notes & e sample there were plenty o & d and sawdust which w & ded in the organic fractiol & & \\
\hline
\end{tabular}




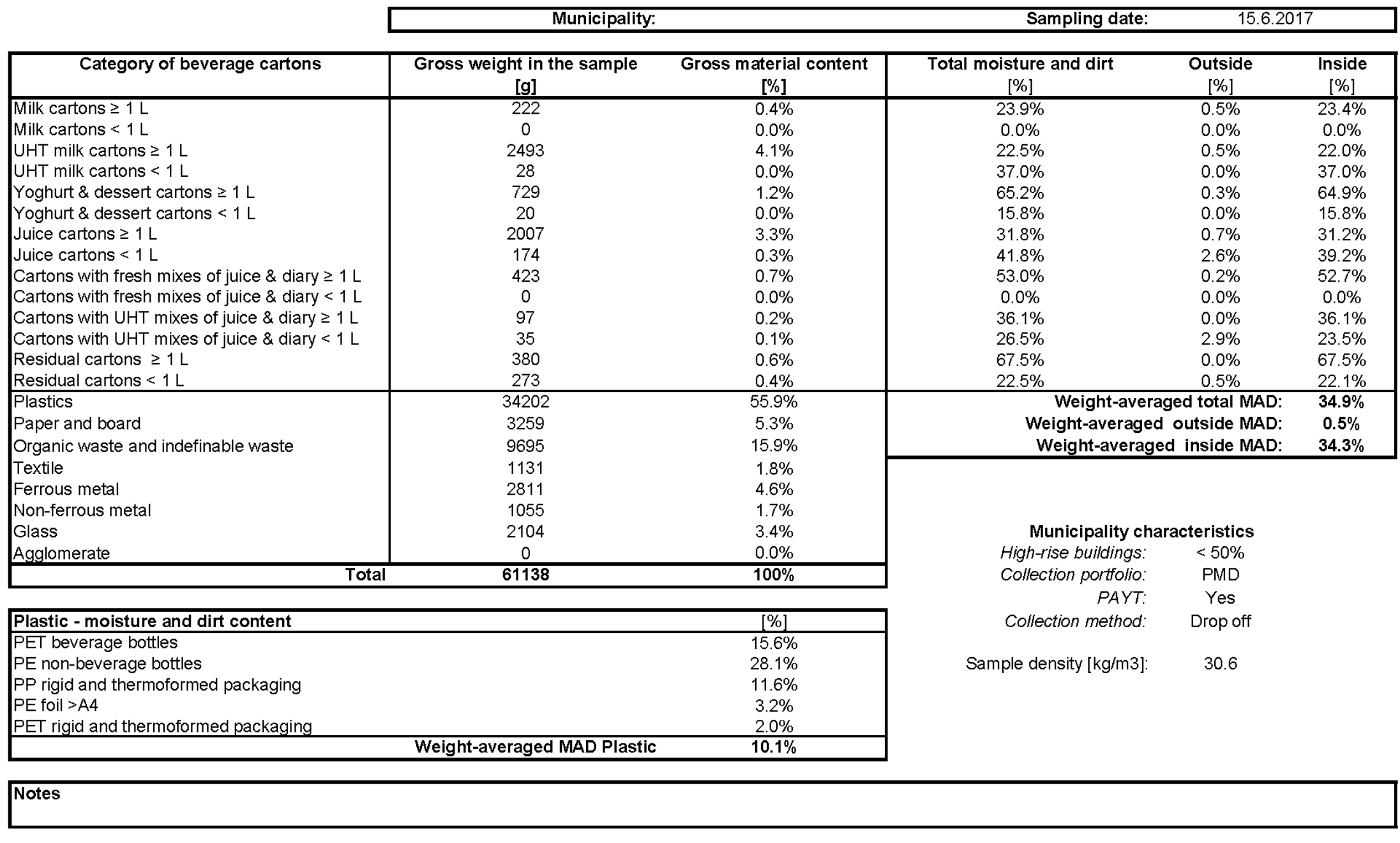




\begin{tabular}{|c|c|c|c|c|c|}
\hline \multirow[b]{2}{*}{ Category of beverage cartons } & \multicolumn{2}{|l|}{ Municipality: } & Sampling date: & \multicolumn{2}{|c|}{14.6 .2017} \\
\hline & $\begin{array}{c}\text { Gross weight in the sample } \\
{[\mathrm{g}]}\end{array}$ & $\begin{array}{c}\text { Gross material content } \\
{[\%]}\end{array}$ & $\begin{array}{c}\text { Total moisture and dirt } \\
{[\%]}\end{array}$ & $\begin{array}{c}\text { Outside } \\
{[\%]}\end{array}$ & $\begin{array}{c}\text { Inside } \\
{[\%]}\end{array}$ \\
\hline Milk cartons $\geq 1 \mathrm{~L}$ & 1346 & $2.3 \%$ & $25.0 \%$ & $0.8 \%$ & $24.2 \%$ \\
\hline Milk cartons $<1 \mathrm{~L}$ & 19 & $0.0 \%$ & $11.1 \%$ & $0.0 \%$ & $11.1 \%$ \\
\hline UHT milk cartons $\geq 1 \mathrm{~L}$ & 322 & $0.5 \%$ & $29.1 \%$ & $0.6 \%$ & $28.4 \%$ \\
\hline UHT milk cartons $<1 \mathrm{~L}$ & 0 & $0.0 \%$ & $0.0 \%$ & $0.0 \%$ & $0.0 \%$ \\
\hline Yoghurt \& dessert cartons $\geq 1 \mathrm{~L}$ & 2601 & $4.4 \%$ & $57.9 \%$ & $0.2 \%$ & $57.7 \%$ \\
\hline Yoghurt \& dessert cartons $<1 \mathrm{~L}$ & 20 & $0.0 \%$ & $11.1 \%$ & $0.0 \%$ & $11.1 \%$ \\
\hline Juice cartons $\geq 1 \mathrm{~L}$ & 904 & $1.5 \%$ & $19.1 \%$ & $0.6 \%$ & $18.5 \%$ \\
\hline Juice cartons $<1 \mathrm{~L}$ & 246 & $0.4 \%$ & $23.9 \%$ & $0.9 \%$ & $23.1 \%$ \\
\hline Cartons with fresh mixes of juice \& diary $\geq 1 \mathrm{~L}$ & 876 & $1.5 \%$ & $61.4 \%$ & $0.2 \%$ & $61.1 \%$ \\
\hline Cartons with fresh mixes of juice \& diary $<1 \mathrm{~L}$ & 0 & $0.0 \%$ & $0.0 \%$ & $0.0 \%$ & $0.0 \%$ \\
\hline Cartons with UHT mixes of juice \& diary $\geq 1 \mathrm{~L}$ & 40 & $0.1 \%$ & $28.9 \%$ & $0.0 \%$ & $28.9 \%$ \\
\hline Cartons with UHT mixes of juice \& diary $<1 \mathrm{~L}$ & 0 & $0.0 \%$ & $0.0 \%$ & $0.0 \%$ & $0.0 \%$ \\
\hline Residual cartons $\geq 1 \mathrm{~L}$ & 45 & $0.1 \%$ & $34.8 \%$ & $0.0 \%$ & $34.8 \%$ \\
\hline Residual cartons $<1 \mathrm{~L}$ & 38 & $0.1 \%$ & $22.2 \%$ & $2.8 \%$ & $19.4 \%$ \\
\hline Plastics & 46948 & $78.6 \%$ & \multirow{3}{*}{\multicolumn{2}{|c|}{$\begin{array}{r}\text { Weight-averaged total MAD: } \\
\text { Weight-averaged outside MAD: } \\
\text { Weight-averaged inside MAD: }\end{array}$}} & $42.5 \%$ \\
\hline Paper and board & 184 & $0.3 \%$ & & & $0.4 \%$ \\
\hline Organic waste and indefinable waste & 1295 & $2.2 \%$ & & & $42.1 \%$ \\
\hline Textile & 274 & $0.5 \%$ & \multirow{5}{*}{\multicolumn{2}{|c|}{ Municipality characteristics }} & \\
\hline Ferrous metal & 3618 & $6.1 \%$ & & & \\
\hline Non-ferrous metal & 567 & $0.9 \%$ & & & \\
\hline Glass & 388 & $0.6 \%$ & & & \\
\hline \multirow{3}{*}{ Agglomerate } & 0 & $0.0 \%$ & & & \\
\hline & 59731 & $100 \%$ & Collection portfolio: & PMD & \\
\hline & & & PAYT: & No & \\
\hline Plastic - moisture and dirt content & & {$[\%]$} & Collection method: & Kerbside & \\
\hline PET beverage bottles & & $17.8 \%$ & & & \\
\hline PE non-beverage bottles & & $19.3 \%$ & Sample density [kg/m3]: & 29.9 & \\
\hline $\mathrm{PP}$ rigid and thermoformed packaging & & $5.9 \%$ & & & \\
\hline$P E$ foil $>A 4$ & & $2.3 \%$ & & & \\
\hline PET rigid and thermoformed packaging & & $1.9 \%$ & & & \\
\hline & Weight-averaged MAD Plastic & $7.2 \%$ & & & \\
\hline Notes & a open Iron c & iner (non-compressed), $\mathrm{c}$ & (on the sun) and sprinkled $w$ & Nater. & \\
\hline
\end{tabular}




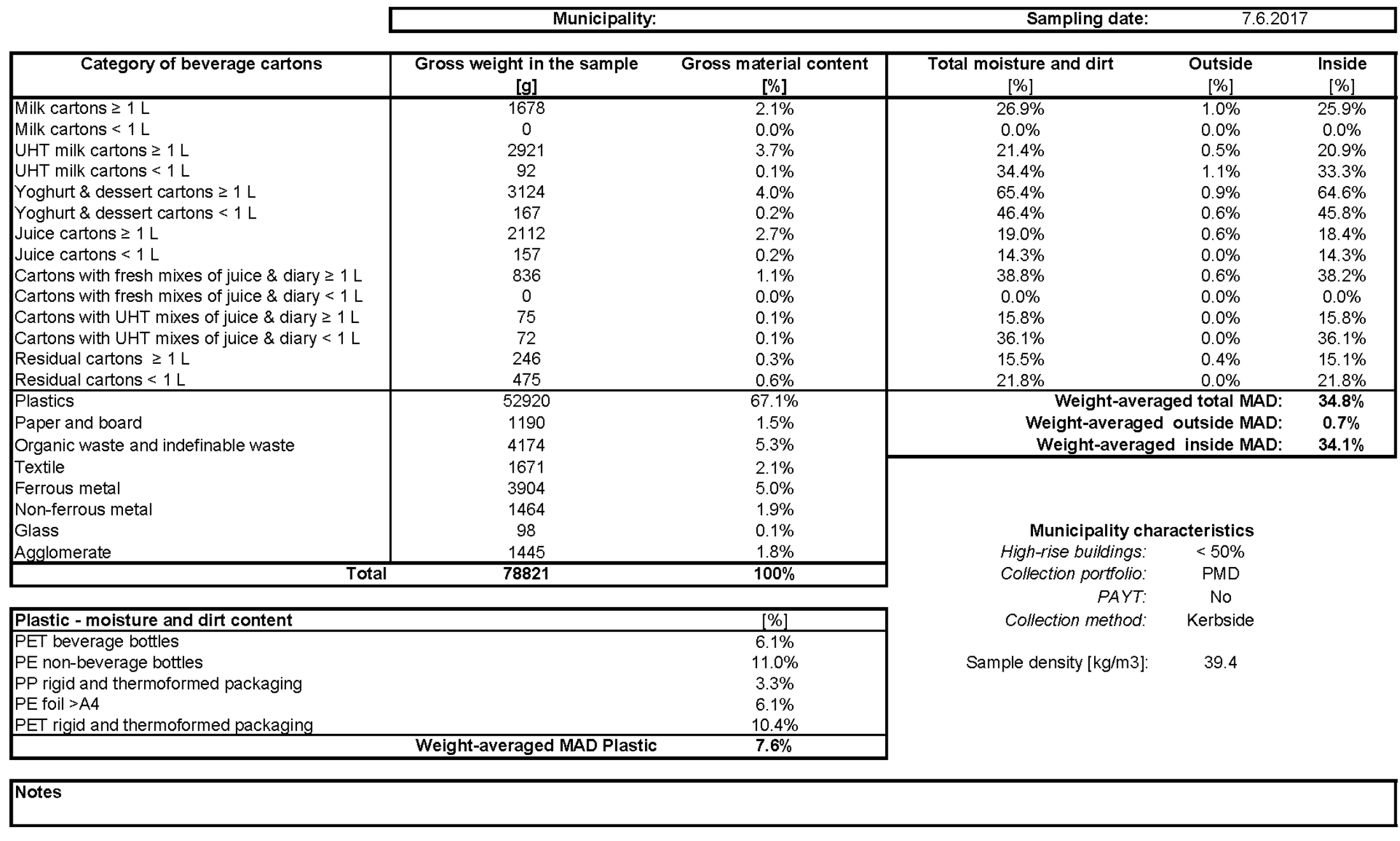




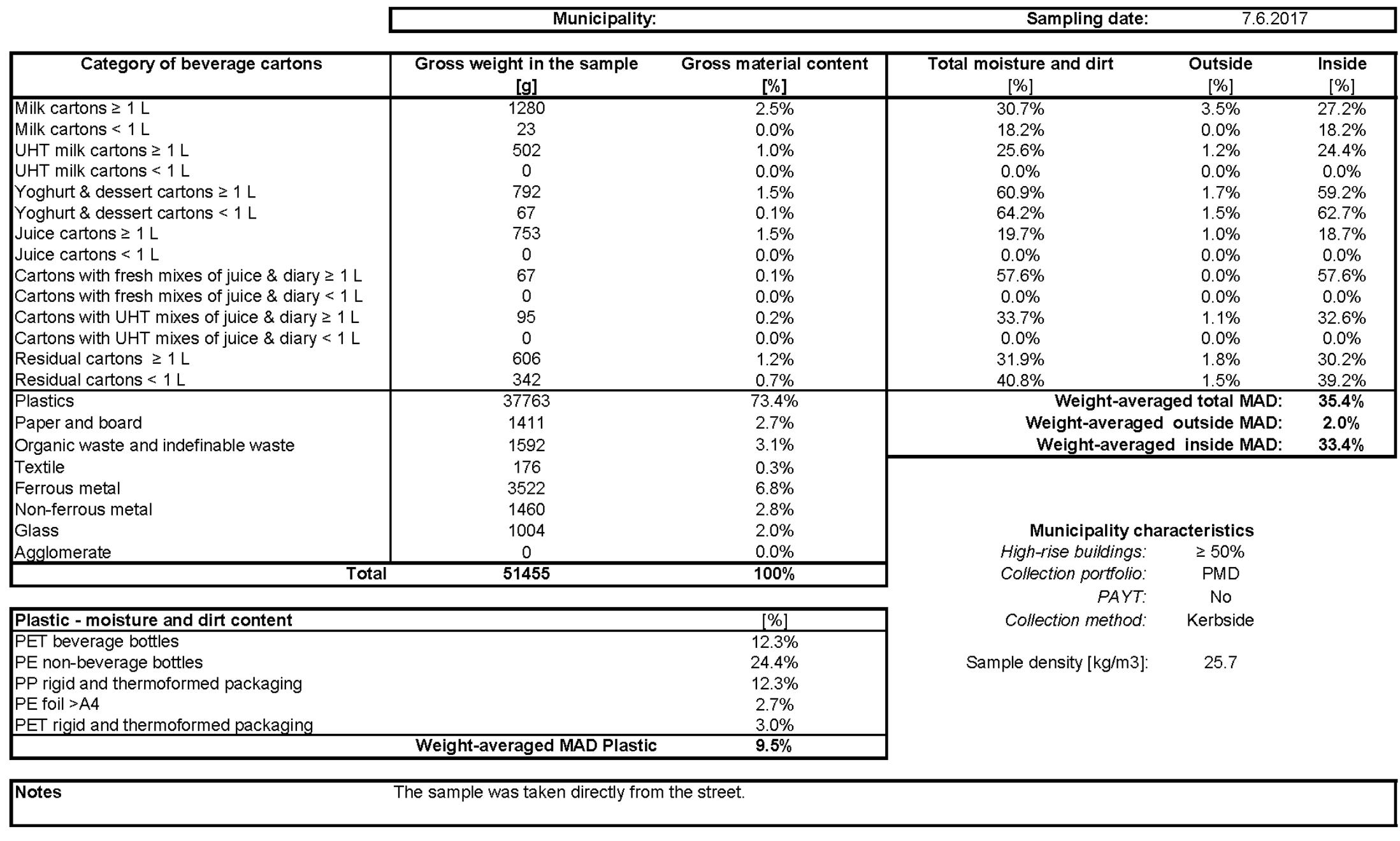




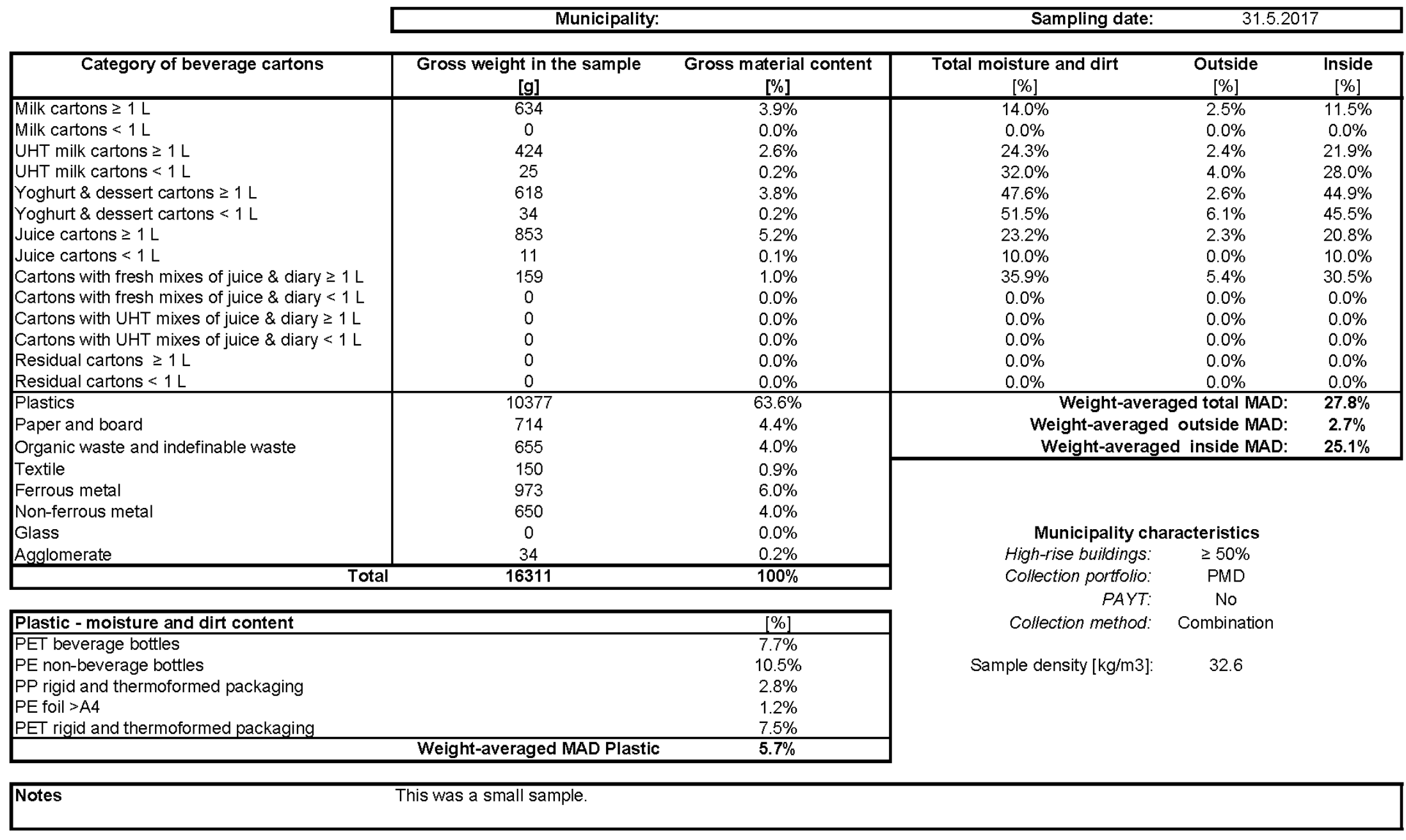




\begin{tabular}{|c|c|c|c|c|c|}
\hline \multirow[b]{2}{*}{ Category of beverage cartons } & \multicolumn{2}{|l|}{ Municipality: } & Sampling date: & \multicolumn{2}{|c|}{31.5 .2017} \\
\hline & $\begin{array}{l}\text { Gross weight in the sample } \\
{[\mathrm{g}]}\end{array}$ & $\begin{array}{c}\text { Gross material content } \\
{[\%]}\end{array}$ & $\begin{array}{c}\text { Total moisture and dirt } \\
{[\%]}\end{array}$ & $\begin{array}{c}\text { Outside } \\
\text { [\%] }\end{array}$ & $\begin{array}{c}\text { Inside } \\
{[\%]}\end{array}$ \\
\hline Milk cartons $\geq 1 \mathrm{~L}$ & 585 & $1.0 \%$ & $24.5 \%$ & $0.3 \%$ & $24.3 \%$ \\
\hline Milk cartons $<1 \mathrm{~L}$ & 0 & $0.0 \%$ & $0.0 \%$ & $0.0 \%$ & $0.0 \%$ \\
\hline UHT milk cartons $\geq 1 \mathrm{~L}$ & 189 & $0.3 \%$ & $30.7 \%$ & $0.0 \%$ & $30.7 \%$ \\
\hline UHT milk cartons $<1 \mathrm{~L}$ & 651 & $1.1 \%$ & $41.8 \%$ & $14.2 \%$ & $27.7 \%$ \\
\hline Yoghurt \& dessert cartons $\geq 1 \mathrm{~L}$ & 636 & $1.1 \%$ & $65.3 \%$ & $1.3 \%$ & $64.0 \%$ \\
\hline Yoghurt \& dessert cartons $<1 \mathrm{~L}$ & 0 & $0.0 \%$ & $0.0 \%$ & $0.0 \%$ & $0.0 \%$ \\
\hline Juice cartons $\geq 1 \mathrm{~L}$ & 1507 & $2.6 \%$ & $23.7 \%$ & $1.2 \%$ & $22.4 \%$ \\
\hline Juice cartons $<1 \mathrm{~L}$ & 7577 & $13.1 \%$ & $24.8 \%$ & $1.7 \%$ & $23.1 \%$ \\
\hline Cartons with fresh mixes of juice \& diary $\geq 1 \mathrm{~L}$ & 63 & $0.1 \%$ & $58.7 \%$ & $1.6 \%$ & $57.1 \%$ \\
\hline Cartons with fresh mixes of juice \& diary $<1 \mathrm{~L}$ & 34 & $0.1 \%$ & $51.5 \%$ & $3.0 \%$ & $48.5 \%$ \\
\hline Cartons with UHT mixes of juice \& diary $\geq 1 \mathrm{~L}$ & 0 & $0.0 \%$ & $0.0 \%$ & $0.0 \%$ & $0.0 \%$ \\
\hline Cartons with UHT mixes of juice \& diary < $1 \mathrm{~L}$ & 528 & $0.9 \%$ & $31.1 \%$ & $3.3 \%$ & $27.9 \%$ \\
\hline Residual cartons $\geq 1 \mathrm{~L}$ & 270 & $0.5 \%$ & $33.6 \%$ & $0.4 \%$ & $33.2 \%$ \\
\hline Residual cartons $<1 \mathrm{~L}$ & 74 & $0.1 \%$ & $27.8 \%$ & $1.4 \%$ & $26.4 \%$ \\
\hline Plastics & 23040 & $39.7 \%$ & \multirow{4}{*}{\multicolumn{2}{|c|}{$\begin{array}{r}\text { Weight-averaged total MAD: } \\
\text { Weight-averaged outside MAD: } \\
\text { Weight-averaged inside MAD: }\end{array}$}} & $28.5 \%$ \\
\hline Paper and board & 7169 & $12.4 \%$ & & & $2.2 \%$ \\
\hline Organic waste and indefinable waste & 6423 & $11.1 \%$ & & & $26.3 \%$ \\
\hline Textile & 1654 & $2.9 \%$ & & & \\
\hline Ferrous metal & 3180 & $5.5 \%$ & \multirow{3}{*}{\multicolumn{2}{|c|}{ Municipality characteristics }} & \\
\hline Non-ferrous metal & 1051 & $1.8 \%$ & & & \\
\hline Glass & 3352 & $5.8 \%$ & & & \\
\hline \multirow{3}{*}{$\begin{array}{ll}\text { Agglomerate } & \\
\end{array}$} & 0 & $0.0 \%$ & High-rise buildings: & $\geq 50 \%$ & \\
\hline & 57983 & $100 \%$ & Collection portfolio: & PMD & \\
\hline & & & PAYT: & No & \\
\hline \multicolumn{2}{|l|}{ Plastic - moisture and dirt content } & {$[\%]$} & Collection method: & Kerbside & \\
\hline \multirow{5}{*}{$\begin{array}{l}\text { PET beverage bottles } \\
\text { PE non-beverage bottles } \\
\text { PP rigid and thermoformed packaging } \\
\text { PE foil }>A 4 \\
\text { PET rigid and thermoformed packaging }\end{array}$} & & $24.9 \%$ & & & \\
\hline & & $19.9 \%$ & Sample density[kg/m3]: & 29.0 & \\
\hline & & $3.7 \%$ & & & \\
\hline & & $6.3 \%$ & & & \\
\hline & & $2.9 \%$ & & & \\
\hline & Weight-averaged MAD Plastic & $10.3 \%$ & & & \\
\hline Notes & $s$ a bag rull & all beverage cartons $p$ & & & \\
\hline
\end{tabular}




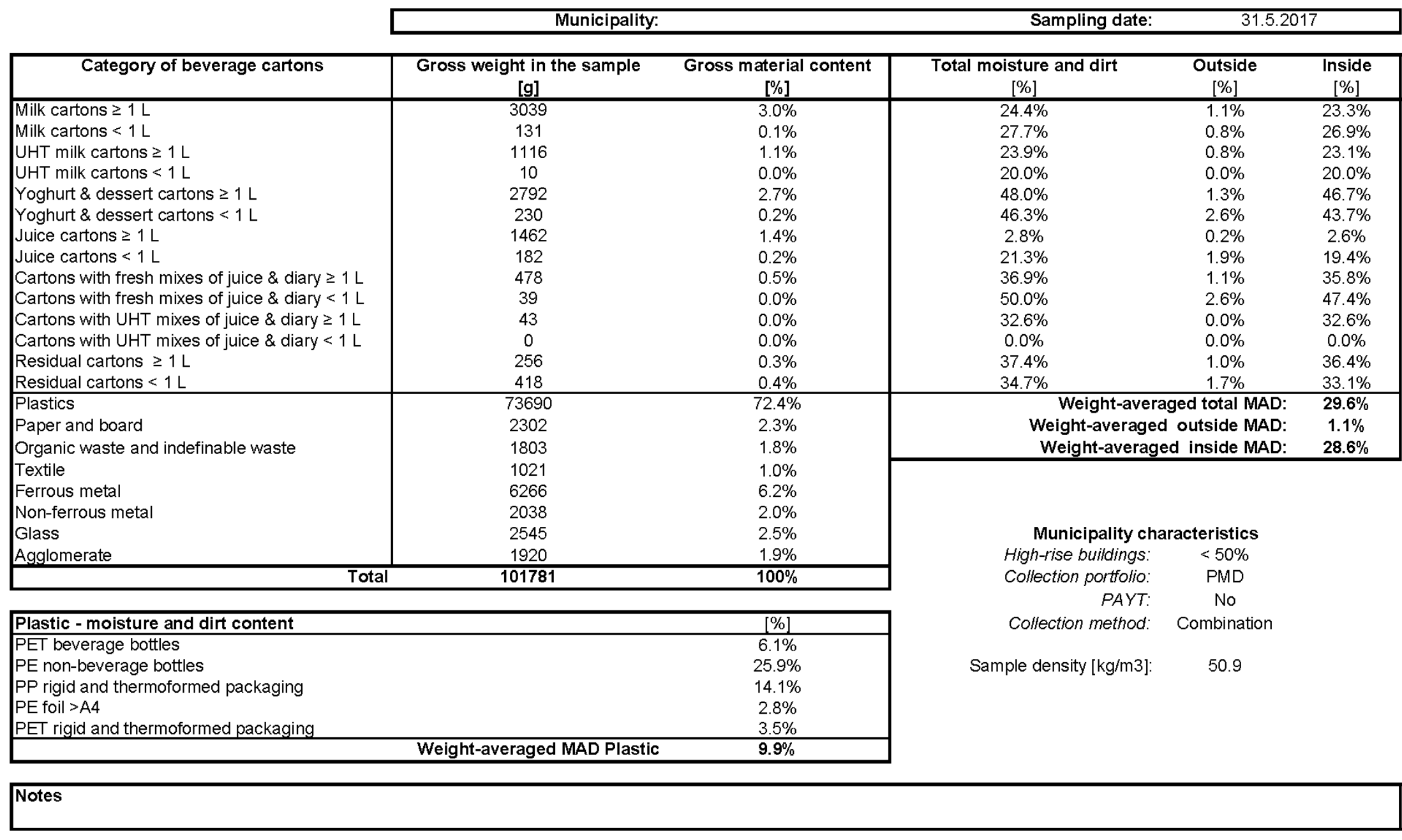




\begin{tabular}{|c|c|c|c|c|c|}
\hline \multirow[b]{2}{*}{ Category of beverage cartons } & \multicolumn{2}{|l|}{ Municipality: } & \multicolumn{3}{|c|}{ Sampling date: } \\
\hline & $\begin{array}{c}\text { Gross weight in the sample } \\
{[\mathrm{g}]}\end{array}$ & $\begin{array}{c}\text { Gross material content } \\
{[\%]}\end{array}$ & $\begin{array}{c}\text { Total moisture and dirt } \\
{[\%]}\end{array}$ & $\begin{array}{c}\text { Outside } \\
{[\%]}\end{array}$ & $\begin{array}{c}\text { Inside } \\
{[\%]}\end{array}$ \\
\hline Milk cartons $\geq 1 \mathrm{~L}$ & 1775 & $1.9 \%$ & $23.5 \%$ & $0.5 \%$ & $23.0 \%$ \\
\hline Milk cartons $<1 \mathrm{~L}$ & 57 & $0.1 \%$ & $24.6 \%$ & $1.8 \%$ & $22.8 \%$ \\
\hline UHT milk cartons $\geq 1 \mathrm{~L}$ & 789 & $0.9 \%$ & $20.2 \%$ & $0.2 \%$ & $20.0 \%$ \\
\hline UHT milk cartons < $1 \mathrm{~L}$ & 40 & $0.0 \%$ & $17.5 \%$ & $0.0 \%$ & $17.5 \%$ \\
\hline Yoghurt \& dessert cartons $\geq 1 \mathrm{~L}$ & 2654 & $2.9 \%$ & $49.9 \%$ & $0.9 \%$ & $49.0 \%$ \\
\hline Yoghurt \& dessert cartons < $1 \mathrm{~L}$ & 297 & $0.3 \%$ & $65.9 \%$ & $0.7 \%$ & $65.2 \%$ \\
\hline Juice cartons $\geq 1 \mathrm{~L}$ & 2502 & $2.7 \%$ & $20.5 \%$ & $1.0 \%$ & $19.5 \%$ \\
\hline Juice cartons $<1 \mathrm{~L}$ & 191 & $0.2 \%$ & $14.0 \%$ & $1.0 \%$ & $13.0 \%$ \\
\hline Cartons with fresh mixes of juice \& diary $\geq 1 \mathrm{~L}$ & 583 & $0.6 \%$ & $48.5 \%$ & $0.9 \%$ & $47.6 \%$ \\
\hline Cartons with fresh mixes of juice \& diary $<1 \mathrm{~L}$ & 132 & $0.1 \%$ & $44.7 \%$ & $1.5 \%$ & $43.2 \%$ \\
\hline Cartons with UHT mixes of juice \& diary $\geq 1 \mathrm{~L}$ & 518 & $0.6 \%$ & $21.8 \%$ & $0.8 \%$ & $21.0 \%$ \\
\hline Cartons with UHT mixes of juice \& diary $<1 \mathrm{~L}$ & 10 & $0.0 \%$ & $10.0 \%$ & $0.0 \%$ & $10.0 \%$ \\
\hline Residual cartons $\geq 1 \mathrm{~L}$ & 306 & $0.3 \%$ & $24.3 \%$ & $0.3 \%$ & $24.0 \%$ \\
\hline Residual cartons $<1 \mathrm{~L}$ & 244 & $0.3 \%$ & $42.0 \%$ & $0.8 \%$ & $41.2 \%$ \\
\hline Plastics & 59560 & $65.0 \%$ & \multirow{3}{*}{\multicolumn{2}{|c|}{$\begin{array}{r}\text { Weight-averaged total MAD: } \\
\text { Weight-averaged outside MAD: } \\
\text { Weight-averaged inside MAD: }\end{array}$}} & $32.6 \%$ \\
\hline Paper and board & 6201 & $6.8 \%$ & & & $0.8 \%$ \\
\hline Organic waste and indefinable waste & 6753 & $7.4 \%$ & & & $31.8 \%$ \\
\hline Textile & 582 & $0.6 \%$ & \multirow{4}{*}{\multicolumn{2}{|c|}{ Municipality characteristics }} & \\
\hline Ferrous metal & 4761 & $5.2 \%$ & & & \\
\hline Non-ferrous metal & 1974 & $2.2 \%$ & & & \\
\hline Glass & 1029 & $1.1 \%$ & & & \\
\hline Agglomerate & 733 & $0.8 \%$ & \multirow{2}{*}{$\begin{array}{l}\text { High-rise building } \\
\text { Collection portfol }\end{array}$} & $<50 \%$ & \\
\hline Total & 91691 & $100 \%$ & & PMD & \\
\hline & & & $P A$ & No & \\
\hline \multicolumn{2}{|l|}{ Plastic - moisture and dirt content } & {$[\%]$} & Collection meth & Drop off & \\
\hline & $7.3 \%$ & & & \\
\hline \multirow{2}{*}{\multicolumn{2}{|c|}{$\begin{array}{l}\text { PE non-beverage bottles } \\
\text { PP rigid and thermoformed packaging }\end{array}$}} & $29.1 \%$ & Sample density $[\mathrm{kg} / \mathrm{m}$ & 45.8 & \\
\hline & & $11.5 \%$ & & & \\
\hline \multirow{2}{*}{\multicolumn{2}{|c|}{$\begin{array}{l}\mathrm{PE} \text { foil > } 44 \\
P E T \text { rigid and thermoformed packaging }\end{array}$}} & $1.0 \%$ & & & \\
\hline & & $2.3 \%$ & & & \\
\hline PET rigid and thermoformed packaging & Weight-averaged MAD Plastic & $9.1 \%$ & & & \\
\hline
\end{tabular}




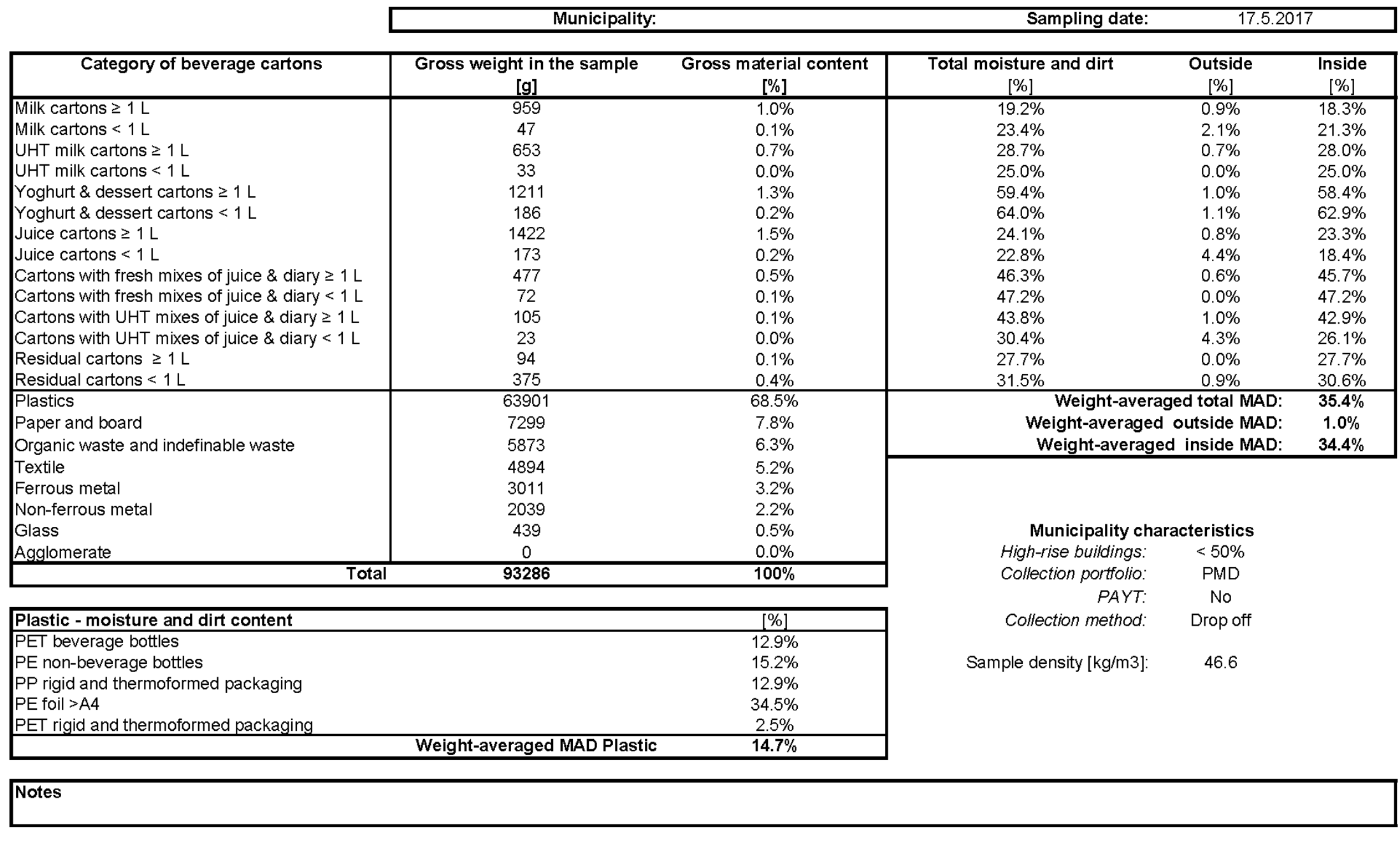




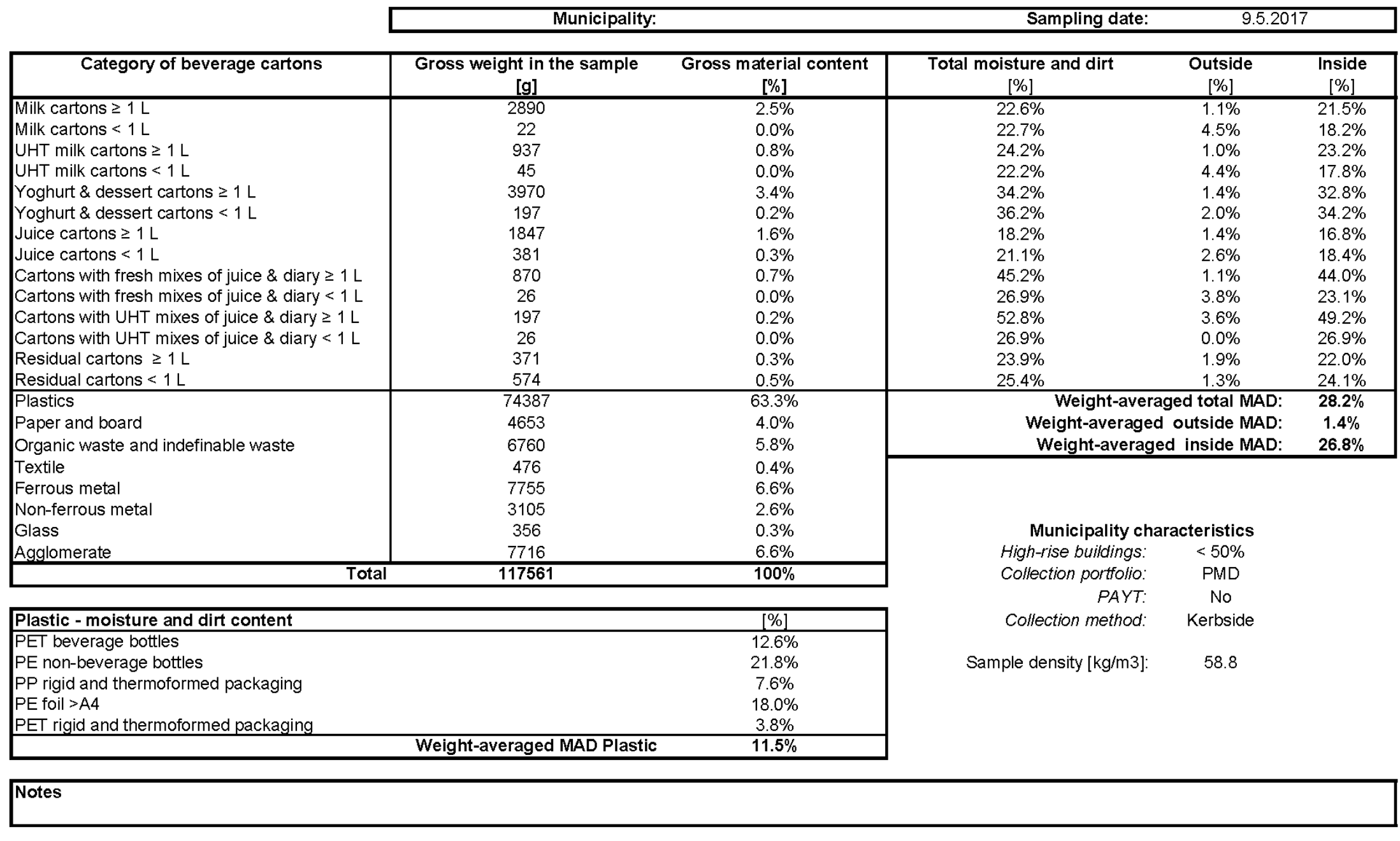




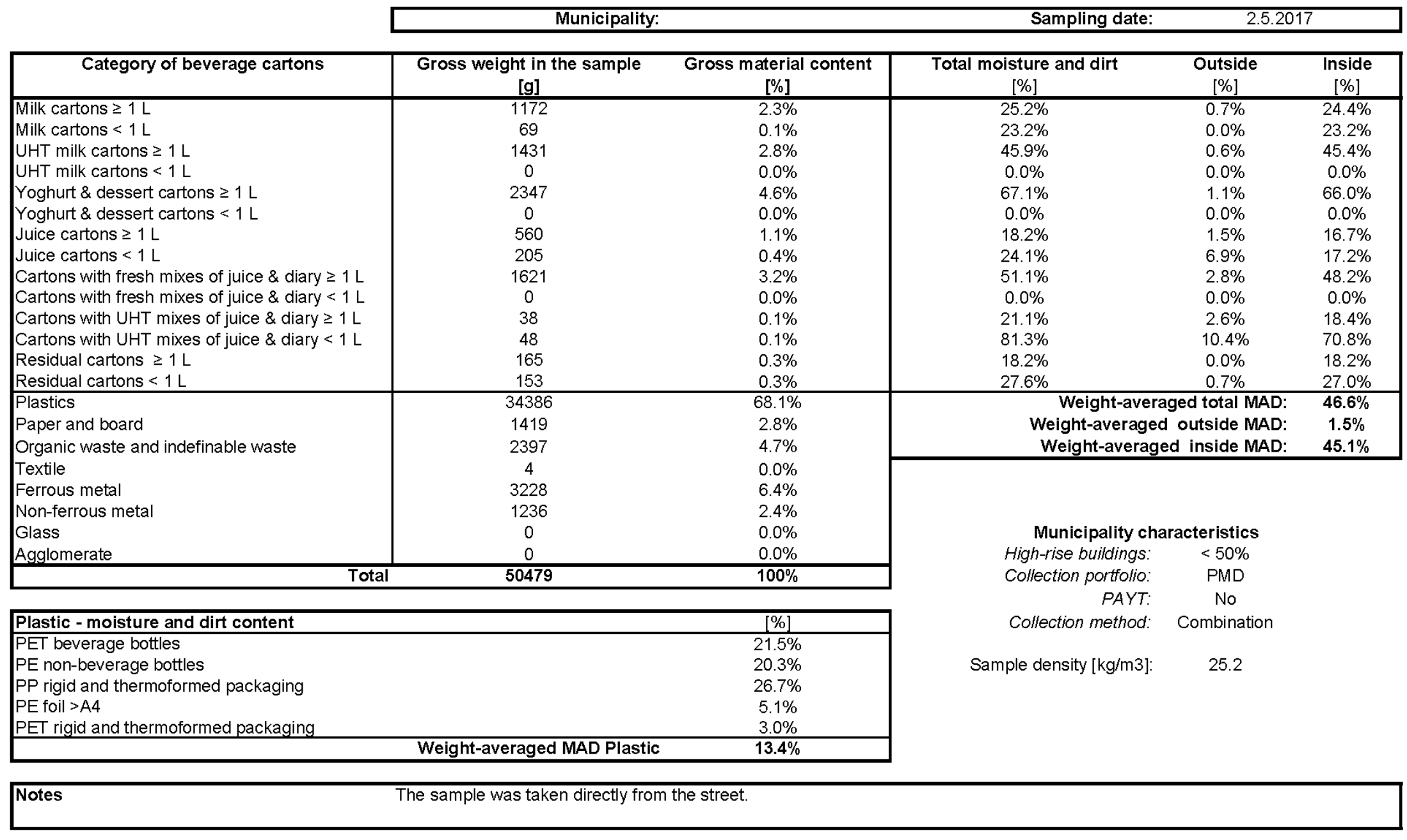




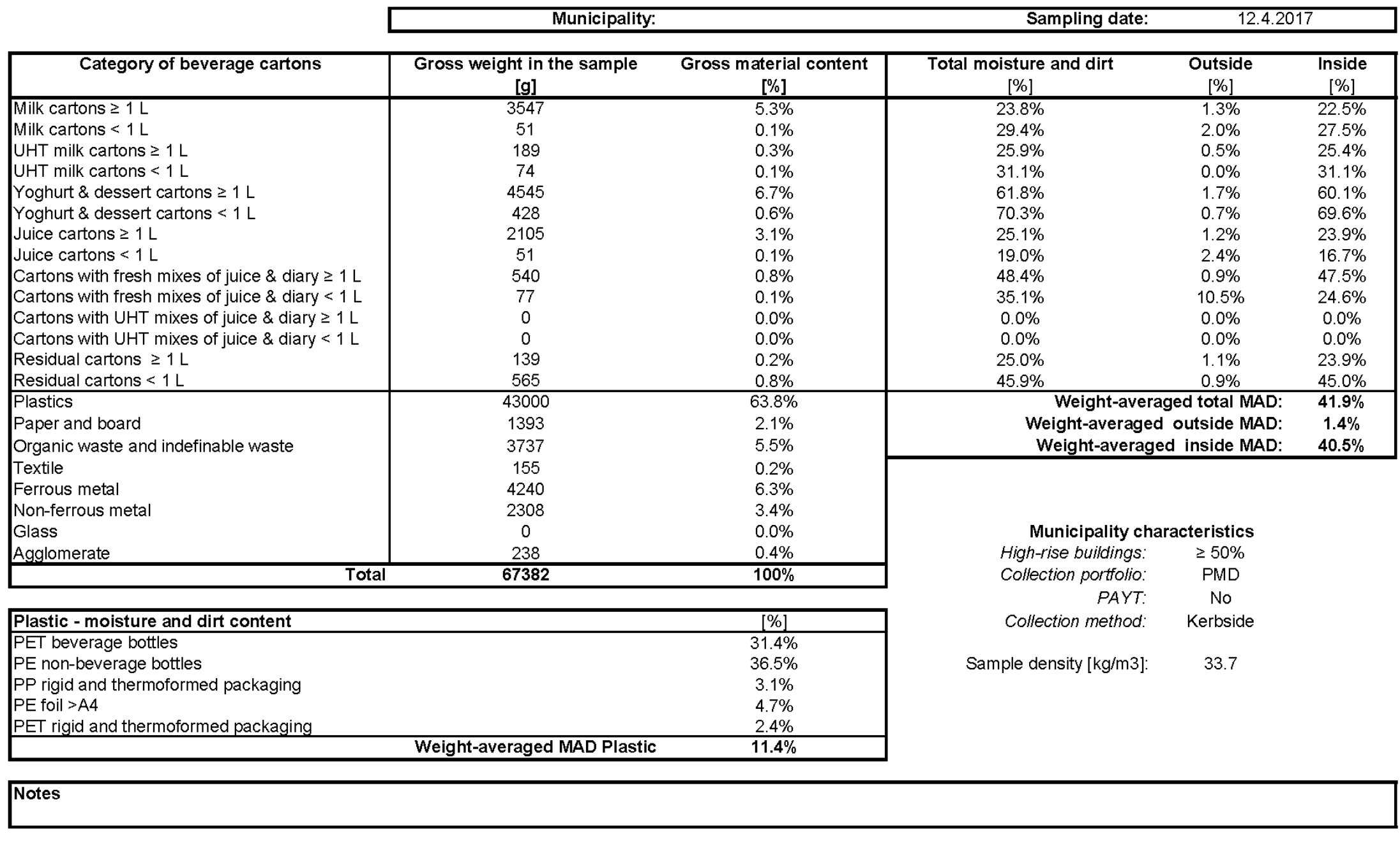




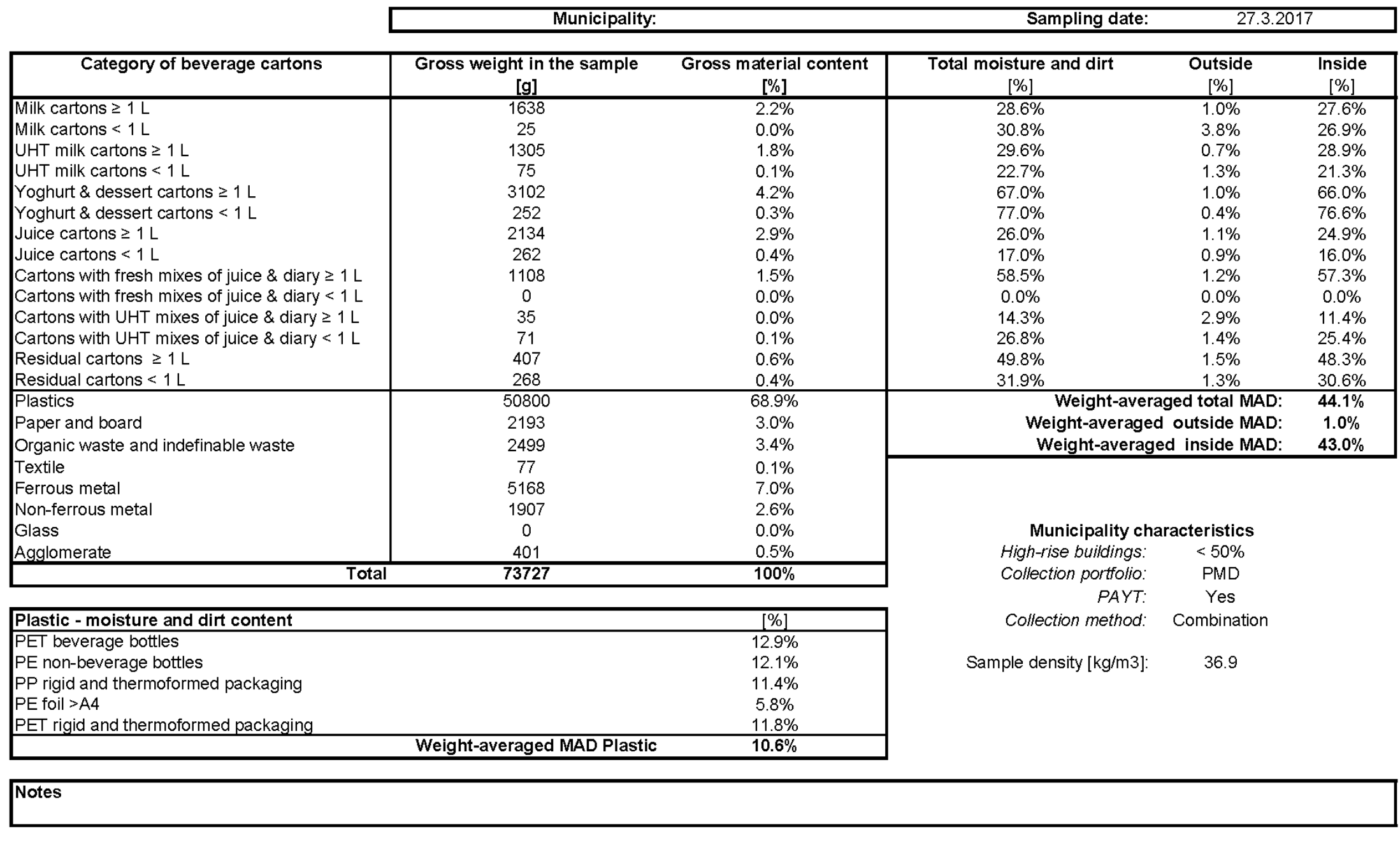




\begin{tabular}{|c|c|c|c|c|c|}
\hline \multirow[b]{2}{*}{ Category of beverage cartons } & \multicolumn{2}{|l|}{ Municipality: } & Sampling date: & \multicolumn{2}{|c|}{20.3 .2017} \\
\hline & $\begin{array}{l}\text { Gross weight in the sample } \\
{[\mathrm{g}]}\end{array}$ & $\begin{array}{c}\text { Gross material content } \\
{[\%]}\end{array}$ & $\begin{array}{c}\text { Total moisture and dirt } \\
{[\%]}\end{array}$ & $\begin{array}{c}\text { Outside } \\
\text { [\%] }\end{array}$ & $\begin{array}{c}\text { Inside } \\
{[\%]}\end{array}$ \\
\hline Milk cartons $\geq 1 \mathrm{~L}$ & 1588 & $1.6 \%$ & $31.1 \%$ & $1.3 \%$ & $29.8 \%$ \\
\hline Milk cartons $<1 \mathrm{~L}$ & 122 & $0.1 \%$ & $22.1 \%$ & $2.5 \%$ & $19.7 \%$ \\
\hline UHT milk cartons $\geq 1 \mathrm{~L}$ & 1087 & $1.1 \%$ & $22.3 \%$ & $2.1 \%$ & $20.1 \%$ \\
\hline UHT milk cartons $<1 \mathrm{~L}$ & 28 & $0.0 \%$ & $13.8 \%$ & $0.0 \%$ & $13.8 \%$ \\
\hline Yoghurt \& dessert cartons $\geq 1 \mathrm{~L}$ & 4942 & $5.1 \%$ & $66.5 \%$ & $2.0 \%$ & $64.5 \%$ \\
\hline Yoghurt \& dessert cartons $<1 \mathrm{~L}$ & 19 & $0.0 \%$ & $21.1 \%$ & $0.0 \%$ & $21.1 \%$ \\
\hline Juice cartons $\geq 1 \mathrm{~L}$ & 2474 & $2.5 \%$ & $21.6 \%$ & $0.9 \%$ & $20.7 \%$ \\
\hline Juice cartons $<1 \mathrm{~L}$ & 124 & $0.1 \%$ & $24.0 \%$ & $4.0 \%$ & $20.0 \%$ \\
\hline Cartons with fresh mixes of juice \& diary $\geq 1 \mathrm{~L}$ & 709 & $0.7 \%$ & $45.2 \%$ & $2.4 \%$ & $42.8 \%$ \\
\hline Cartons with fresh mixes of juice \& diary $<1 \mathrm{~L}$ & 0 & $0.0 \%$ & $0.0 \%$ & $0.0 \%$ & $0.0 \%$ \\
\hline Cartons with UHT mixes of juice \& diary $\geq 1 \mathrm{~L}$ & 51 & $0.1 \%$ & $43.1 \%$ & $0.0 \%$ & $43.1 \%$ \\
\hline Cartons with UHT mixes of juice \& diary $<1 \mathrm{~L}$ & 163 & $0.2 \%$ & $30.6 \%$ & $3.3 \%$ & $27.3 \%$ \\
\hline Residual cartons $\geq 1 \mathrm{~L}$ & 509 & $0.5 \%$ & $26.9 \%$ & $0.6 \%$ & $26.3 \%$ \\
\hline Residual cartons $<1 \mathrm{~L}$ & 471 & $0.5 \%$ & $44.1 \%$ & $2.0 \%$ & $42.1 \%$ \\
\hline Plastics & 64350 & $66.2 \%$ & \multirow{3}{*}{\multicolumn{2}{|c|}{$\begin{array}{r}\text { Weight-averaged total MAD: } \\
\text { Weight-averaged outside MAD: } \\
\text { Weight-averaged inside MAD: }\end{array}$}} & $43.6 \%$ \\
\hline Paper and board & 6500 & $6.7 \%$ & & & $1.7 \%$ \\
\hline Organic waste and indefinable waste & 5294 & $5.4 \%$ & & & $41.9 \%$ \\
\hline Textile & 1139 & $1.2 \%$ & \multirow{4}{*}{\multicolumn{2}{|c|}{ Municipality characteristics }} & \\
\hline Ferrous metal & 4760 & $4.9 \%$ & & & \\
\hline Non-ferrous metal & 1858 & $1.9 \%$ & & & \\
\hline Glass & 103 & $0.1 \%$ & & & \\
\hline \multirow{3}{*}{ Agglomerate } & 13 & $0.9 \%$ & High-rise buildings: & $<50 \%$ & \\
\hline & 97206 & $100 \%$ & Collection portfolio: & PMD & \\
\hline & & & PAYT: & Yes & \\
\hline Plastic - moisture and dirt content & & {$[\%]$} & Collection method: & Kerbside & \\
\hline PET beverage bottles & & $13.1 \%$ & & & \\
\hline PE non-beverage bottles & & $30.1 \%$ & Sample density $[\mathrm{kg} / \mathrm{m} 3]$ : & 48.6 & \\
\hline PP rigid and thermoformed packaging & & $3.0 \%$ & & & \\
\hline$P E$ foil $>A 4$ & & $11.4 \%$ & & & \\
\hline PET rigid and thermoformed packaging & & $19.1 \%$ & & & \\
\hline & Weight-averaged MAD Plastic & $15.2 \%$ & & & \\
\hline Notes & & & & & \\
\hline
\end{tabular}




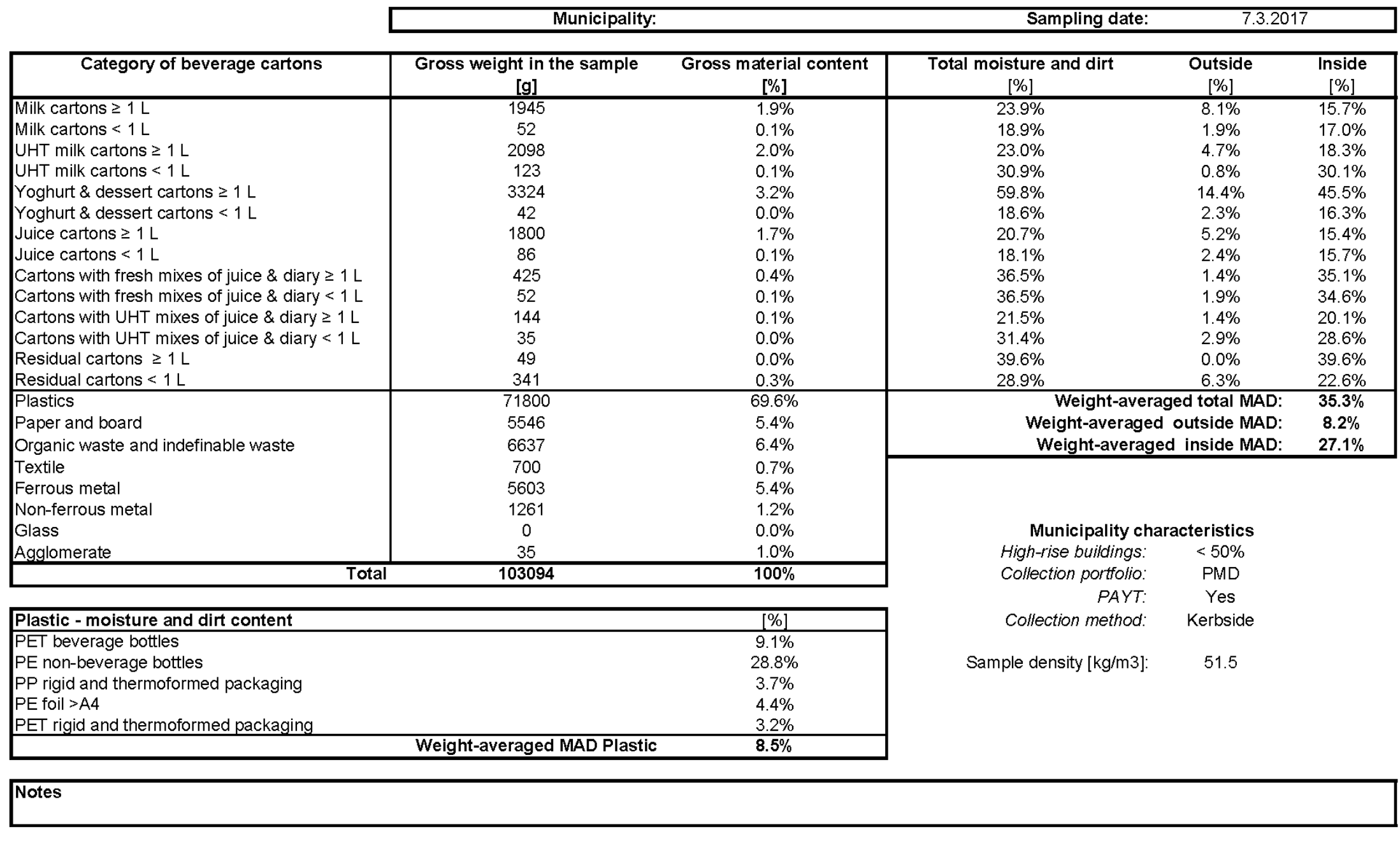




\begin{tabular}{|c|c|c|c|c|c|}
\hline \multirow[b]{2}{*}{ Category of beverage cartons } & \multicolumn{2}{|l|}{ Municipality: } & Sampling date: & \multicolumn{2}{|c|}{18.1 .2017} \\
\hline & $\begin{array}{c}\text { Gross weight in the sample } \\
{[\mathrm{g}]}\end{array}$ & $\begin{array}{c}\text { Gross material content } \\
{[\%]}\end{array}$ & $\begin{array}{c}\text { Total moisture and dirt } \\
{[\%]}\end{array}$ & $\begin{array}{c}\text { Outside } \\
{[\%]}\end{array}$ & $\begin{array}{c}\text { Inside } \\
{[\%]}\end{array}$ \\
\hline Milk cartons $\geq 1 \mathrm{~L}$ & 2932 & $3.0 \%$ & $23.9 \%$ & $1.4 \%$ & $22.5 \%$ \\
\hline Milk cartons $<1 \mathrm{~L}$ & 272 & $0.3 \%$ & $22.0 \%$ & $2.4 \%$ & $19.5 \%$ \\
\hline UHT milk cartons $\geq 1 \mathrm{~L}$ & 2438 & $2.5 \%$ & $27.7 \%$ & $1.4 \%$ & $26.4 \%$ \\
\hline UHT milk cartons $<1 \mathrm{~L}$ & 6 & $0.0 \%$ & $0 \%$ * & $0.0 \%$ & $0.0 \%$ \\
\hline Yoghurt \& dessert cartons $\geq 1 \mathrm{~L}$ & 5348 & $5.5 \%$ & $64.5 \%$ & $1.3 \%$ & $63.2 \%$ \\
\hline Yoghurt \& dessert cartons $<1 \mathrm{~L}$ & 257 & $0.3 \%$ & $57.9 \%$ * & $0.0 \%$ & $57.9 \%$ \\
\hline Juice cartons $\geq 1 \mathrm{~L}$ & 3294 & $3.4 \%$ & $20.4 \%$ & $0.6 \%$ & $19.8 \%$ \\
\hline Juice cartons $<1 \mathrm{~L}$ & 427 & $0.4 \%$ & $12.6 \%$ & $1.0 \%$ & $11.7 \%$ \\
\hline Cartons with fresh mixes of juice \& diary $\geq 1 \mathrm{~L}$ & 375 & $0.4 \%$ & $47.5 \%$ * & $0.0 \%$ & $47.5 \%$ \\
\hline Cartons with fresh mixes of juice \& diary $<1 \mathrm{~L}$ & 278 & $0.3 \%$ & $49.1 \%^{*}$ & $0.0 \%$ & $49.1 \%$ \\
\hline Cartons with UHT mixes of juice \& diary $\geq 1 \mathrm{~L}$ & 87 & $0.1 \%$ & $35.6 \%$ * & $0.0 \%$ & $35.6 \%$ \\
\hline Cartons with UHT mixes of juice \& diary $<1 \mathrm{~L}$ & 33 & $0.0 \%$ & $28.6 \%$ * & $0.0 \%$ & $28.6 \%$ \\
\hline Residual cartons $\geq 1 \mathrm{~L}$ & 920 & $1.0 \%$ & $20.7 \%$ & $0.4 \%$ & $20.2 \%$ \\
\hline Residual cartons $<1 \mathrm{~L}$ & 460 & $0.5 \%$ & $32.0 \%$ & $0.0 \%$ & $32.0 \%$ \\
\hline Plastics & 54691 & $56.7 \%$ & \multirow{3}{*}{\multicolumn{2}{|c|}{$\begin{array}{l}\text { Weight-averaged total MAD: } \\
\text { Weight-averaged outside MAD: } \\
\text { Weight-averaged inside MAD: }\end{array}$}} & $37.7 \%$ \\
\hline Paper and board & 7520 & $7.8 \%$ & & & $1.0 \%$ \\
\hline Organic waste and indefinable waste & 5149 & $5.3 \%$ & & & $36.6 \%$ \\
\hline Textile & 225 & $0.2 \%$ & \multirow{4}{*}{\multicolumn{2}{|c|}{${ }^{*}$ only tota/ MAD was determined }} & \\
\hline Ferrous metal & 5566 & $5.8 \%$ & & & \\
\hline Non-ferrous metal & 3513 & $3.6 \%$ & & & \\
\hline Glass & 0 & $0.0 \%$ & & & \\
\hline \multirow{3}{*}{$\begin{array}{ll}\text { Agglomerate } & \\
\end{array}$} & 40 & $2.8 \%$ & High-rise buildings: & $<50 \%$ & \\
\hline & 96484 & $100 \%$ & Collection portfolio: & PMD & \\
\hline & & & PAYT: & Yes & \\
\hline Plastic - moisture and dirt content & & {$[\%]$} & Collection method: & Kerbside & \\
\hline PET beverage bottles & & $58.8 \%$ & & & \\
\hline PE non-beverage bottles & & $15.6 \%$ & Sample density $[\mathrm{kg} / \mathrm{m} 3]$ : & 48.2 & \\
\hline PP rigid and thermoformed packaging & & $8.8 \%$ & & & \\
\hline$P E$ foil $>A 4$ & & $12.7 \%$ & & & \\
\hline PET rigid and thermoformed packaging & & $4.1 \%$ & & & \\
\hline & Weight-averaged MAD Plastic & $13.0 \%$ & & & \\
\hline Notes & & & & & \\
\hline
\end{tabular}




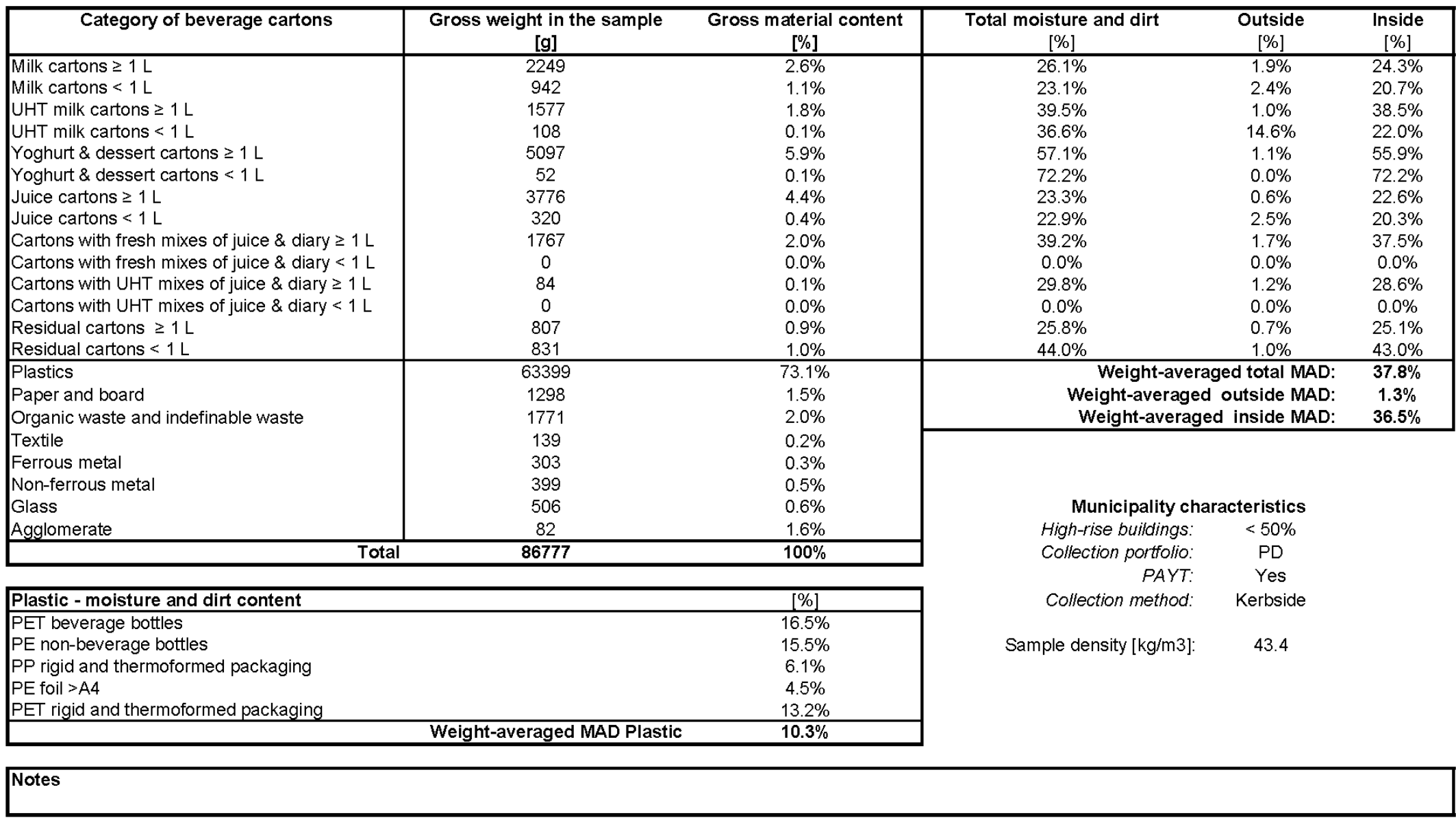




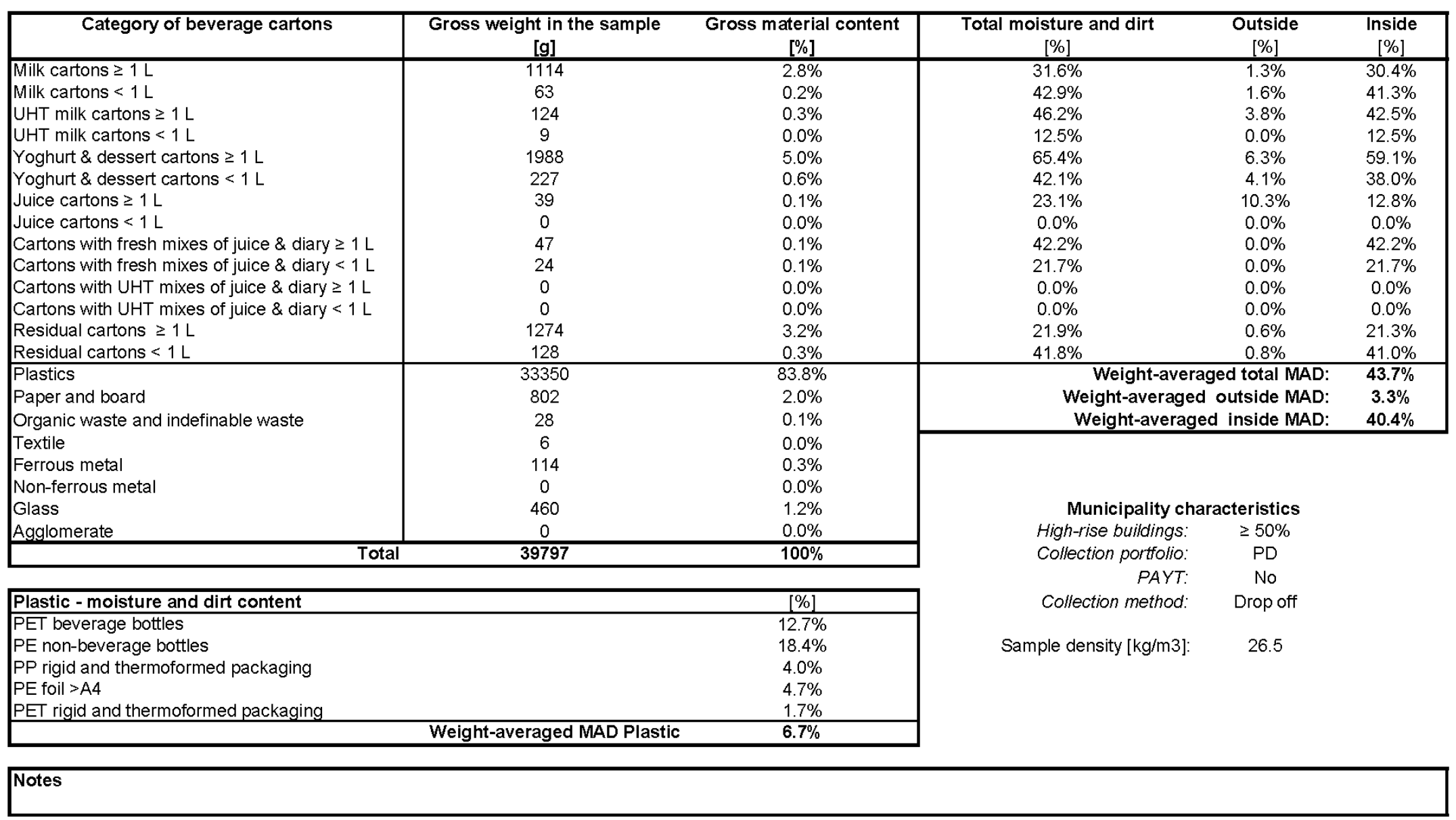




\begin{tabular}{|c|c|c|c|c|c|}
\hline \multirow[b]{2}{*}{ Category of beverage cartons } & \multicolumn{2}{|l|}{ Municipality: } & Sampling date: & \multicolumn{2}{|c|}{2.5 .2017} \\
\hline & $\begin{array}{l}\text { Gross weight in the sample } \\
{[\mathrm{g}]}\end{array}$ & $\begin{array}{c}\text { Gross material content } \\
{[\%]}\end{array}$ & $\begin{array}{c}\text { Total moisture and dirt } \\
{[\%]}\end{array}$ & $\begin{array}{c}\text { Outside } \\
\text { [\%] }\end{array}$ & $\begin{array}{c}\text { Inside } \\
{[\%]}\end{array}$ \\
\hline Milk cartons $\geq 1 \mathrm{~L}$ & 2443 & $1.5 \%$ & $28.9 \%$ & $3.2 \%$ & $25.7 \%$ \\
\hline Milk cartons $<1 \mathrm{~L}$ & 40 & $0.0 \%$ & $17.5 \%$ & $2.5 \%$ & $15.0 \%$ \\
\hline UHT milk cartons $\geq 1 \mathrm{~L}$ & 1359 & $0.8 \%$ & $26.8 \%$ & $2.0 \%$ & $24.9 \%$ \\
\hline UHT milk cartons $<1 \mathrm{~L}$ & 142 & $0.1 \%$ & $28.0 \%$ & $2.5 \%$ & $25.4 \%$ \\
\hline Yoghurt \& dessert cartons $\geq 1 \mathrm{~L}$ & 1990 & $1.2 \%$ & $53.7 \%$ & $4.4 \%$ & $49.3 \%$ \\
\hline Yoghurt \& dessert cartons $<1 \mathrm{~L}$ & 307 & $0.2 \%$ & $62.1 \%$ & $7.0 \%$ & $55.1 \%$ \\
\hline Juice cartons $\geq 1 \mathrm{~L}$ & 1923 & $1.2 \%$ & $19.2 \%$ & $2.2 \%$ & $17.1 \%$ \\
\hline Juice cartons $<1 \mathrm{~L}$ & 341 & $0.2 \%$ & $39.7 \%$ & $9.6 \%$ & $30.1 \%$ \\
\hline Cartons with fresh mixes of juice \& diary $\geq 1 \mathrm{~L}$ & 1012 & $0.6 \%$ & $38.5 \%$ & $2.3 \%$ & $36.2 \%$ \\
\hline Cartons with fresh mixes of juice \& diary $<1 \mathrm{~L}$ & 49 & $0.0 \%$ & $29.2 \%$ & $2.1 \%$ & $27.1 \%$ \\
\hline Cartons with UHT mixes of juice \& diary $\geq 1 \mathrm{~L}$ & 40 & $0.0 \%$ & $22.5 \%$ & $0.0 \%$ & $22.5 \%$ \\
\hline Cartons with UHT mixes of juice \& diary $<1$ L & 48 & $0.0 \%$ & $29.8 \%$ & $4.3 \%$ & $25.5 \%$ \\
\hline Residual cartons $\geq 1 \mathrm{~L}$ & 83 & $0.1 \%$ & $18.1 \%$ & $1.2 \%$ & $16.9 \%$ \\
\hline Residual cartons $<1 \mathrm{~L}$ & 259 & $0.2 \%$ & $33.5 \%$ & $3.4 \%$ & $30.0 \%$ \\
\hline Plastics & 93600 & $56.6 \%$ & \multirow{3}{*}{\multicolumn{2}{|c|}{$\begin{array}{r}\text { Weight-averaged total MAD: } \\
\text { Weight-averaged outside MAD: } \\
\text { Weight-averaged inside MAD: }\end{array}$}} & $34.0 \%$ \\
\hline Paper and board & 9173 & $5.5 \%$ & & & $3.3 \%$ \\
\hline Organic waste and indefinable waste & 23940 & $14.5 \%$ & & & $31 \%$ \\
\hline Textile & 3107 & $1.9 \%$ & \multirow{4}{*}{\multicolumn{2}{|c|}{ Municipality characteristics }} & \\
\hline Ferrous metal & 13092 & $7.9 \%$ & & & \\
\hline Non-ferrous metal & 6336 & $3.8 \%$ & & & \\
\hline Glass & 2162 & $1.3 \%$ & & & \\
\hline \multirow{3}{*}{$\begin{array}{l}\text { Agglomerate } \\
\end{array}$} & 3850 & $2.3 \%$ & High-rise buildings: & $<50 \%$ & \\
\hline & 165296 & $100 \%$ & Collection portfolio: & PD & \\
\hline & & & PAYT: & No & \\
\hline Plastic - moisture and dirt content & & {$[\%]$} & Collection method: & Drop off & \\
\hline PET beverage bottles & & $34.0 \%$ & & & \\
\hline PE non-beverage bottles & & $24.5 \%$ & Sample density $[\mathrm{kg} / \mathrm{m} 3]$ : & 82.6 & \\
\hline PP rigid and thermoformed packaging & & $14.2 \%$ & & & \\
\hline PE foil > A4 & & $14.1 \%$ & & & \\
\hline PET rigid and thermoformed packaging & & $17.1 \%$ & & & \\
\hline & Weight-averaged MAD Plastic & $18.5 \%$ & & & \\
\hline Notes & $y$ (full of sand, br & es, twigs and metals). & & & \\
\hline
\end{tabular}




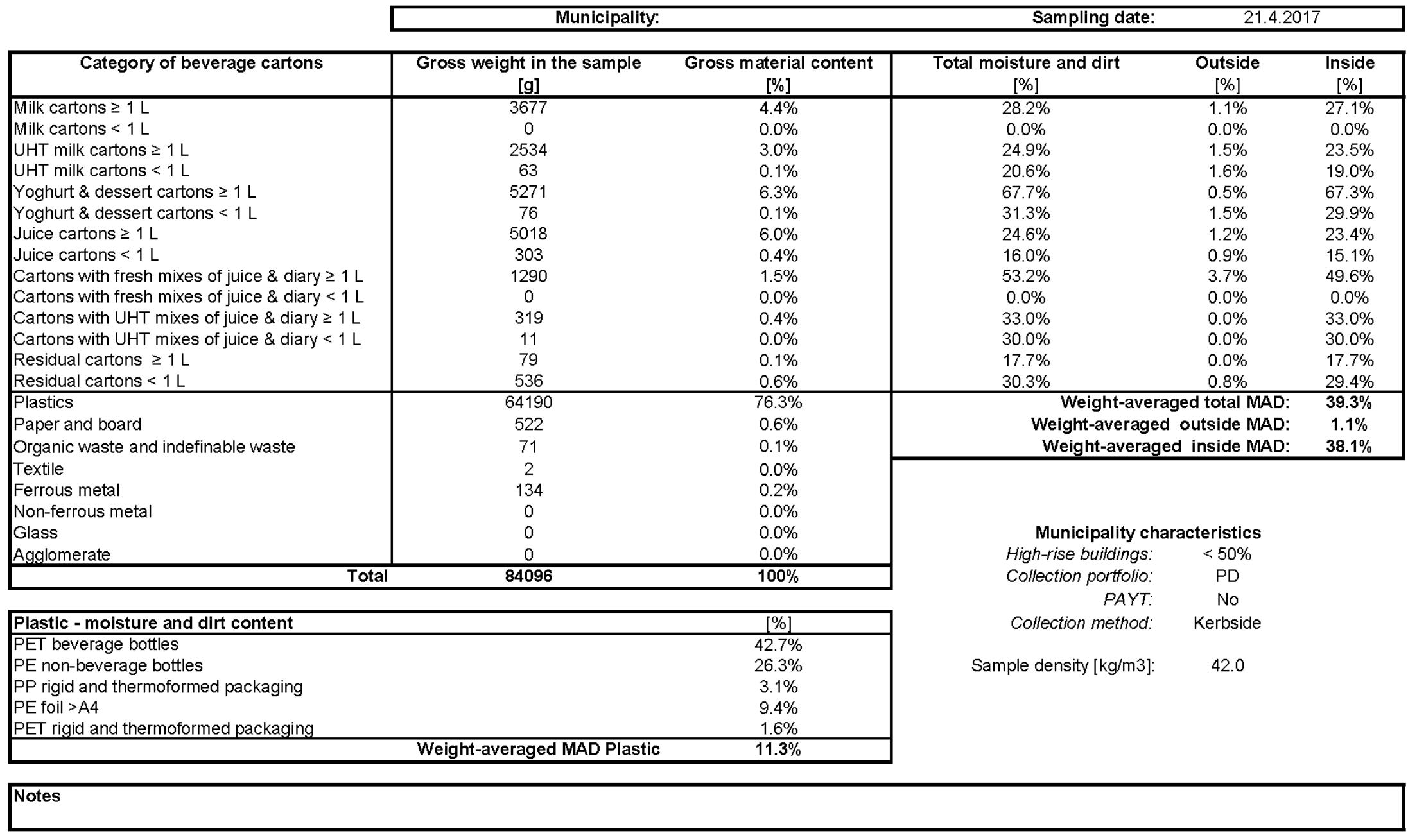




\begin{tabular}{|c|c|c|c|c|c|}
\hline Category of beverage cartons & $\begin{array}{l}\text { Gross weight in the sample } \\
{[\text { [g] }}\end{array}$ & $\begin{array}{c}\text { Gross material content } \\
{[\%]}\end{array}$ & $\begin{array}{c}\text { Total moisture and dirt } \\
{[\%]}\end{array}$ & $\begin{array}{c}\text { Outside } \\
{[\%]}\end{array}$ & $\begin{array}{c}\text { Inside } \\
{[\%]}\end{array}$ \\
\hline Milk cartons $\geq 1 \mathrm{~L}$ & 10675 & $15.9 \%$ & $31.3 \%$ & $3.8 \%$ & $27.5 \%$ \\
\hline Milk cartons $<1 \mathrm{~L}$ & 490 & $0.7 \%$ & $25.3 \%$ & $3.5 \%$ & $21.8 \%$ \\
\hline UHT milk cartons $\geq 1 \mathrm{~L}$ & 8359 & $12.4 \%$ & $27.8 \%$ & $3.0 \%$ & $24.8 \%$ \\
\hline UHT milk cartons $<1 \mathrm{~L}$ & 166 & $0.2 \%$ & $18.6 \%$ & $2.3 \%$ & $16.3 \%$ \\
\hline Yoghurt $\&$ dessert cartons $\geq 1 \mathrm{~L}$ & 8903 & $13.2 \%$ & $52.3 \%$ & $3.3 \%$ & $49.0 \%$ \\
\hline Yoghurt \& dessert cartons $<1 \mathrm{~L}$ & 233 & $0.3 \%$ & $45.9 \%$ * & $0.0 \%$ & $45.9 \%$ \\
\hline Juice cartons $\geq 1 \mathrm{~L}$ & 15348 & $22.8 \%$ & $25.7 \%$ & $3.5 \%$ & $22.3 \%$ \\
\hline Juice cartons $<1 \mathrm{~L}$ & 873 & $1.3 \%$ & $22.6 \%$ & $4.3 \%$ & $18.3 \%$ \\
\hline Cartons with fresh mixes of juice $\&$ diary $\geq 1 \mathrm{~L}$ & 3290 & $4.9 \%$ & $39.5 \%$ & $3.2 \%$ & $36.4 \%$ \\
\hline Cartons with fresh mixes of juice $\&$ diary $<1 \mathrm{~L}$ & 103 & $0.2 \%$ & $38.10 \%$ * & $0.0 \%$ & $38.1 \%$ \\
\hline Cartons with UHT mixes of juice \& diary $\geq 1 \mathrm{~L}$ & 629 & $0.9 \%$ & $22.0 \%$ & $2.7 \%$ & $19.3 \%$ \\
\hline Cartons with UHT mixes of juice \& diary $<1$ L & 166 & $0.2 \%$ & $26.1 \%$ & $0.0 \%$ & $26.1 \%$ \\
\hline Residual cartons $\geq 1 \mathrm{~L}$ & 2675 & $4.0 \%$ & $28.6 \%$ & $4.7 \%$ & $24.0 \%$ \\
\hline Residual cartons $<1 \mathrm{~L}$ & 1600 & $2.4 \%$ & $29.8 \%$ & $3.4 \%$ & $26.4 \%$ \\
\hline Plastics & 3762 & $5.6 \%$ & \multirow{3}{*}{\multicolumn{2}{|c|}{$\begin{array}{l}\text { Weight-averaged total MAD } \\
\text { Weight-averaged outside MAD }\end{array}$}} & $32.7 \%$ \\
\hline Paper and board & 6588 & $9.8 \%$ & & & $3.4 \%$ \\
\hline Organic waste and indefinable waste & 2768 & $4.1 \%$ & & & $29.2 \%$ \\
\hline
\end{tabular}

Organic waste and indefinable waste

Textile

Ferrous metal

Glass

Agglomerate

\begin{tabular}{r|r} 
& 391 \\
& 0 \\
& 0 \\
\hline
\end{tabular}

"only total MAD was determined

Municipality characteristics

High-rise buildings:

Collection porffolio: Sorted product

Plastic - moisture and dirt content 67260

$\mathrm{PP}$ rigid and thermoformed packaging

$P E$ foil $>A 4$

$\mathrm{PET}$ rigid and thermoformed packaging

Notes: This is the sample from the $* \ldots *$ and it represents "gesorteerde drankenkartons" (sorted beverage cartons). The metal fraction was not divided on ferro and non-ferro (all is isted all as a ferro), the plastic fraction was not washed and analysed, it was only sorted on types. 


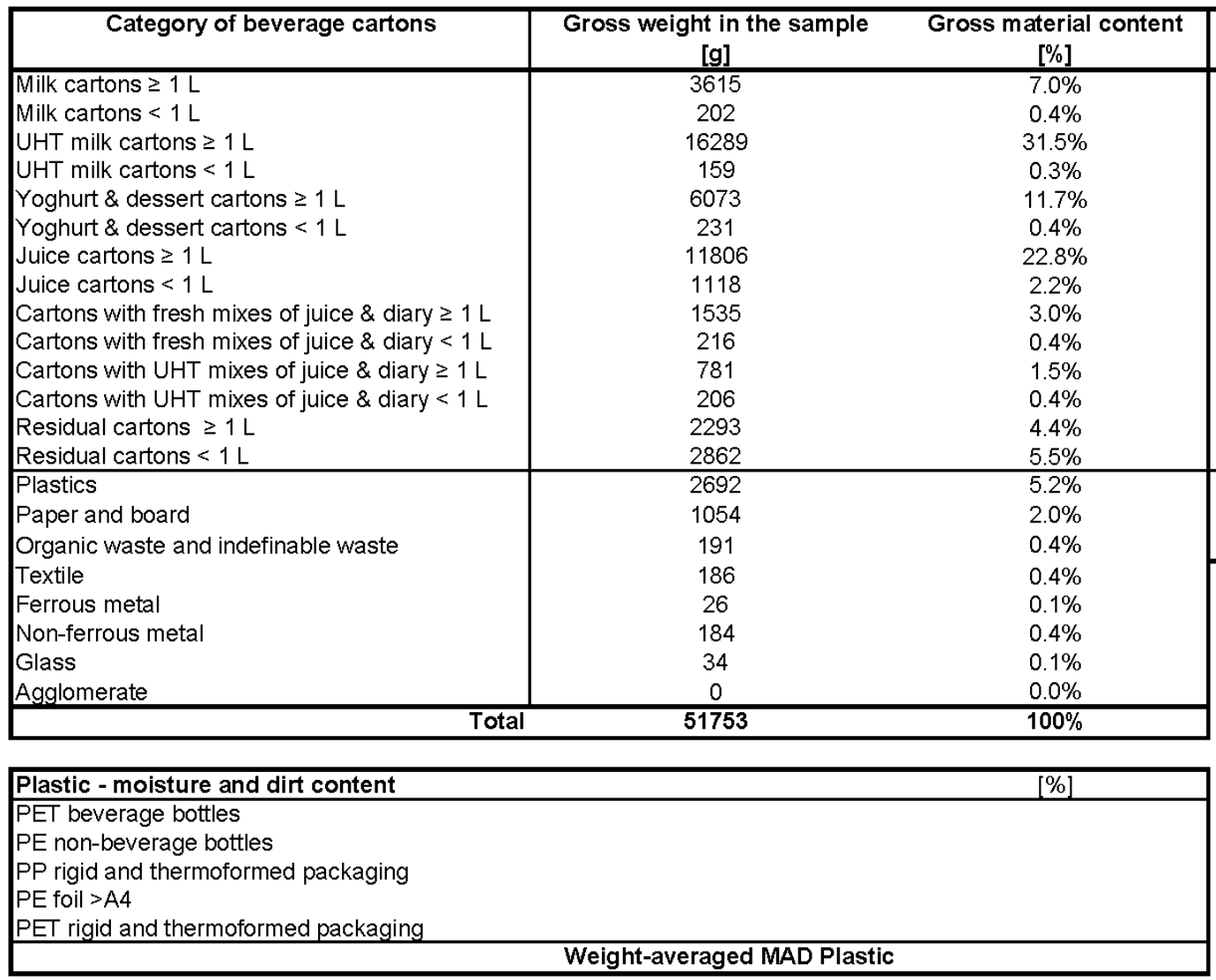

\begin{tabular}{|l} 
Total mo \\
\hline
\end{tabular}

[\%]
$30.5 \%$

$29.2 \%$

$\begin{array}{lll}25.4 \% & 2.5 \% & 26.7 \% \\ 3.6 \% & 23 \%\end{array}$

$\begin{array}{lll}25.2 \% & 2.3 \% & 32.8 \%\end{array}$

$\begin{array}{lll}33.4 \% & 1.8 \% & 31.6 \% \\ 55.8 \% & 0.9 \% & 55.0 \%\end{array}$

\begin{tabular}{lll}
$1.8 \%$ & $55.0 \%$ \\
\hline & $1.5 \%$ & $20 \%$
\end{tabular}

$\begin{array}{lll}22.4 \% & 1.5 \% & 20.9 \%\end{array}$

$\begin{array}{lll}22.6 \% & 2.6 \% & 20.0 \%\end{array}$

$\begin{array}{lll}43.3 \% & 1.6 \% & 41.7 \%\end{array}$

$\begin{array}{lll}37.7 \% & 1.9 \% & 35.8 \%\end{array}$

$\begin{array}{lll}32.2 \% & 1.8 \% & 30.4 \%\end{array}$

$\begin{array}{lll}33.3 \% & 2.5 \% & 30.8 \%\end{array}$

\begin{tabular}{lll}
$25.1 \%$ & $1.3 \%$ & $23.8 \%$ \\
\hline
\end{tabular}

$\begin{array}{cc}1.6 \% & 27.6 \% \\ \text { Weight-averaged total MAD: } & \mathbf{2 7 . 2} \%\end{array}$

Weight-averaged outside MAD: $\quad 1.7 \%$

Weight-averaged inside MAD:

$25.5 \%$

Municipality characteristics High-rise buildings: Collection portfolio: Sorted product

Collection method:

Sample density $[\mathrm{kg} / \mathrm{m} 3]$ : $\quad 69.0$

Weight-averaged MAD Plastic

Notes 


\begin{tabular}{|c|c|c|c|c|c|}
\hline & Sorted product, separate co & llection & Sampling da & 29.6 .26 & \\
\hline Category of beverage cartons & $\begin{array}{l}\text { Gross weight in the sample } \\
{[\mathrm{g}]}\end{array}$ & $\begin{array}{c}\text { Gross material content } \\
{[\%]}\end{array}$ & $\begin{array}{c}\text { Total moisture and dirt } \\
{[\%]}\end{array}$ & $\begin{array}{l}\text { Outside } \\
\text { [\%] }\end{array}$ & $\begin{array}{c}\text { Inside } \\
{[\%]}\end{array}$ \\
\hline Milk cartons $\geq 1 \mathrm{~L}$ & 8866 & $16.6 \%$ & $14.3 \%$ & $1.2 \%$ & $13.1 \%$ \\
\hline Milk cartons $<1 \mathrm{~L}$ & 143 & $0.3 \%$ & $24.5 \%$ & $2.2 \%$ & $22.3 \%$ \\
\hline UHT milk cartons $\geq 1 \mathrm{~L}$ & 8051 & $15.1 \%$ & $20.1 \%$ & $1.9 \%$ & $18.2 \%$ \\
\hline UHT milk cartons $<1 \mathrm{~L}$ & 219 & $0.4 \%$ & $20.4 \%$ & $1.9 \%$ & $18.4 \%$ \\
\hline Yoghurt \& dessert cartons $\geq 1 \mathrm{~L}$ & 8637 & $16.2 \%$ & $31.5 \%$ & $1.9 \%$ & $29.6 \%$ \\
\hline Yoghurt \& dessert cartons < $1 \mathrm{~L}$ & 485 & $0.9 \%$ & $28.2 \%$ & $2.3 \%$ & $25.9 \%$ \\
\hline Juice cartons $\geq 1 \mathrm{~L}$ & 12316 & $23.1 \%$ & $15.5 \%$ & $0.8 \%$ & $14.7 \%$ \\
\hline Juice cartons $<1 \mathrm{~L}$ & 824 & $1.5 \%$ & $23.9 \%$ & $1.7 \%$ & $22.2 \%$ \\
\hline Cartons with fresh mixes of juice \& diary $\geq 1 \mathrm{~L}$ & 3174 & $5.9 \%$ & $26.5 \%$ & $2.1 \%$ & $24.4 \%$ \\
\hline Cartons with fresh mixes of juice \& diary < $1 \mathrm{~L}$ & 142 & $0.3 \%$ & $25.0 \%$ & $2.9 \%$ & $22.1 \%$ \\
\hline Cartons with UHT mixes of juice \& diary $\geq 1 \mathrm{~L}$ & 566 & $1.1 \%$ & $28.1 \%$ & $2.1 \%$ & $26.0 \%$ \\
\hline Cartons with UHT mixes of juice \& diary $<1 \mathrm{~L}$ & 97 & $0.2 \%$ & $22.9 \%$ & $2.1 \%$ & $20.8 \%$ \\
\hline Residual cartons $\geq 1 \mathrm{~L}$ & 1333 & $2.5 \%$ & $16.2 \%$ & $1.1 \%$ & $15.0 \%$ \\
\hline Residual cartons $<1 \mathrm{~L}$ & 1399 & $2.6 \%$ & $24.7 \%$ & $1.8 \%$ & $22.9 \%$ \\
\hline Plastics & 5160 & $9.7 \%$ & Weight-a & aged total MAD: & $20.7 \%$ \\
\hline Paper and board & 1433 & $2.7 \%$ & Weight-aver & d outsid MAD: & $1.5 \%$ \\
\hline Organic waste and indefinable waste & 511 & $1.0 \%$ & Weight-ave & ed inside MAD: & $19.2 \%$ \\
\hline Textile & 2 & $0.0 \%$ & & & \\
\hline Ferrous metal & 0 & $0.0 \%$ & & & \\
\hline Non-ferrous metal & 0 & $0.0 \%$ & & & \\
\hline Glass & 35 & $0.1 \%$ & Municipality & aracteristics & \\
\hline Agglomerate & 0 & $0.0 \%$ & High-rise buildin & & \\
\hline Total & 53393 & $100 \%$ & Collection portfol & Sorted product & \\
\hline & & & $P A Y$ & - & \\
\hline Plastic - moisture and dirt content & & {$[\%]$} & Collection meth & - & \\
\hline PET beverage bottles & & & & & \\
\hline PE non-beverage bottles & & - & Sample density $[\mathrm{kg} / \mathrm{m}$ & 71.2 & \\
\hline $\begin{array}{l}P P \text { rigid and thermoformed packaging } \\
P F \text { foil >A4 }\end{array}$ & & - & & & \\
\hline $\begin{array}{l}\text { PE foil >A4 } \\
\text { PET rigid and thermoformed packaging }\end{array}$ & & - & & & \\
\hline & Weight-averaged MAD Plastic & - & & & \\
\hline
\end{tabular}




\begin{tabular}{|c|c|c|c|c|c|}
\hline & Sorted product, separate collection & llection & Sampling date: & \multicolumn{2}{|c|}{17.5 .2017} \\
\hline Category of beverage cartons & $\begin{array}{l}\text { Gross weight in the sample } \\
{[\mathrm{g}]}\end{array}$ & $\begin{array}{c}\text { Gross material content } \\
{[\%]}\end{array}$ & $\begin{array}{c}\text { Total moisture and dirt } \\
{[\%]}\end{array}$ & $\begin{array}{c}\text { Outside } \\
\text { [\%] }\end{array}$ & $\begin{array}{c}\text { Inside } \\
{[\%]}\end{array}$ \\
\hline Milk cartons $\geq 1 \mathrm{~L}$ & 9291 & $19.8 \%$ & $31.6 \%$ & $2.0 \%$ & $29.6 \%$ \\
\hline Milk cartons $<1 \mathrm{~L}$ & 134 & $0.3 \%$ & $25.8 \%$ & $3.0 \%$ & $22.7 \%$ \\
\hline UHT milk cartons $\geq 1 \mathrm{~L}$ & 7504 & $16.0 \%$ & $23.7 \%$ & $2.1 \%$ & $21.6 \%$ \\
\hline UHT milk cartons $<1 \mathrm{~L}$ & 257 & $0.5 \%$ & $22.2 \%$ & $2.8 \%$ & $19.4 \%$ \\
\hline Yoghurt \& dessert cartons $\geq 1 \mathrm{~L}$ & 7095 & $15.1 \%$ & $42.6 \%$ & $1.7 \%$ & $40.9 \%$ \\
\hline Yoghurt \& dessert cartons $<1 \mathrm{~L}$ & 390 & $0.8 \%$ & $34.9 \%$ & $2.2 \%$ & $32.7 \%$ \\
\hline Juice cartons $\geq 1 \mathrm{~L}$ & 9581 & $20.4 \%$ & $18.4 \%$ & $1.5 \%$ & $16.9 \%$ \\
\hline Juice cartons $<1 \mathrm{~L}$ & 639 & $1.4 \%$ & $23.5 \%$ & $3.4 \%$ & $20.2 \%$ \\
\hline Cartons with fresh mixes of juice \& diary $\geq 1 \mathrm{~L}$ & 2693 & $5.7 \%$ & $32.1 \%$ & $2.2 \%$ & $30.0 \%$ \\
\hline Cartons with fresh mixes of juice \& diary $<1 \mathrm{~L}$ & 160 & $0.3 \%$ & $33.9 \%$ & $0.6 \%$ & $33.3 \%$ \\
\hline Cartons with UHT mixes of juice \& diary $\geq 1 \mathrm{~L}$ & 569 & $1.2 \%$ & $29.4 \%$ & $2.2 \%$ & $27.2 \%$ \\
\hline Cartons with UHT mixes of juice \& diary $<1 \mathrm{~L}$ & 95 & $0.2 \%$ & $20.5 \%$ & $2.3 \%$ & $18.2 \%$ \\
\hline Residual cartons $\geq 1 \mathrm{~L}$ & 2693 & $5.7 \%$ & $24.5 \%$ & $2.0 \%$ & $22.5 \%$ \\
\hline Residual cartons $<1 \mathrm{~L}$ & 1424 & $3.0 \%$ & $27.7 \%$ & $2.0 \%$ & $25.8 \%$ \\
\hline Plastics & 2385 & $5.1 \%$ & \multirow{3}{*}{\multicolumn{2}{|c|}{$\begin{array}{r}\text { Weight-averaged total MAD: } \\
\text { Weight-averaged outside MAD: } \\
\text { Weight-averaged inside MAD: }\end{array}$}} & $28.3 \%$ \\
\hline Paper and board & 745 & $1.6 \%$ & & & $1.9 \%$ \\
\hline Organic waste and indefinable waste & 308 & $0.7 \%$ & & & $26.4 \%$ \\
\hline Textile & 51 & $0.1 \%$ & \multirow{7}{*}{\multicolumn{2}{|c|}{\begin{tabular}{rc}
\multicolumn{2}{c}{ Municipality characteristics } \\
High-rise buildings: & - \\
Collection portfolio: & Sorted product \\
PAYT: & -
\end{tabular}}} & \\
\hline Ferrous metal & 0 & $0.0 \%$ & & & \\
\hline Non-ferrous metal & 0 & $0.0 \%$ & & & \\
\hline Glass & 4 & $0.0 \%$ & & & \\
\hline Agglomerate & 861 & $1.8 \%$ & & & \\
\hline Total & 46879 & $100 \%$ & & & \\
\hline & & & & & \\
\hline \multicolumn{2}{|l|}{ Plastic - moisture and dirt content } & {$[\%]$} & \multirow{6}{*}{$\begin{array}{l}\text { Collection method: } \\
\text { Sample density [kg/m3]: }\end{array}$} & \multirow[t]{2}{*}{-} & \\
\hline \multirow{5}{*}{$\begin{array}{l}\text { PET beverage bottles } \\
\text { PE non-beverage bottles } \\
\text { PP rigid and thermoformed packaging } \\
\text { PE foil >A4 } \\
\text { PET rigid and thermoformed packaging }\end{array}$} & & - & & & \\
\hline & & - & & \multirow[t]{4}{*}{133.9} & \\
\hline & & - & & & \\
\hline & & - & & & \\
\hline & & - & & & \\
\hline & Weight-averaged MAD Plastic & - & & & \\
\hline
\end{tabular}




\section{Appendix B: Input Data into STAN}

Input data for reconciliation in STAN with the net beverage carton weights and the concomitant errors. [kg net/a]

\begin{tabular}{|l|l|l|l|l|l|}
\hline & & \multicolumn{2}{|l|}{ Input STAN calculation } & \multicolumn{2}{l|}{ Output STAN calculation } \\
\hline Input 1 & PMD & 16036445 & 641458 & 15709631 & 607254 \\
\hline Input 2 & PD & 4803670 & 360275 & 4700576 & 354327 \\
\hline Input 3 & Mono-P & 62747 & 3137 & 62739 & 3137 \\
\hline Output 1 & PET & 3787 & 4234 & 3801 & 4234 \\
\hline Output 2 & PE & 5553 & 2936 & 5560 & 2936 \\
\hline Output 3 & PP & 18739 & 11229 & 18839 & 11229 \\
\hline Output 4 & FILM & 11338 & 9604 & 11411 & 9604 \\
\hline Output 5 & MIX & 958831 & 395310 & 1082950 & 387440 \\
\hline Output 6 & BC & 14305092 & 960377 & 15037660 & 841261 \\
\hline Output 7 & Sorting residue & 2387614 & 1528226 & 4242595 & 979525 \\
\hline Output 8 & Metals & 63473 & 91547 & 70130 & 91450 \\
\hline
\end{tabular}




\section{Appendix C: Material Flow Schemes}

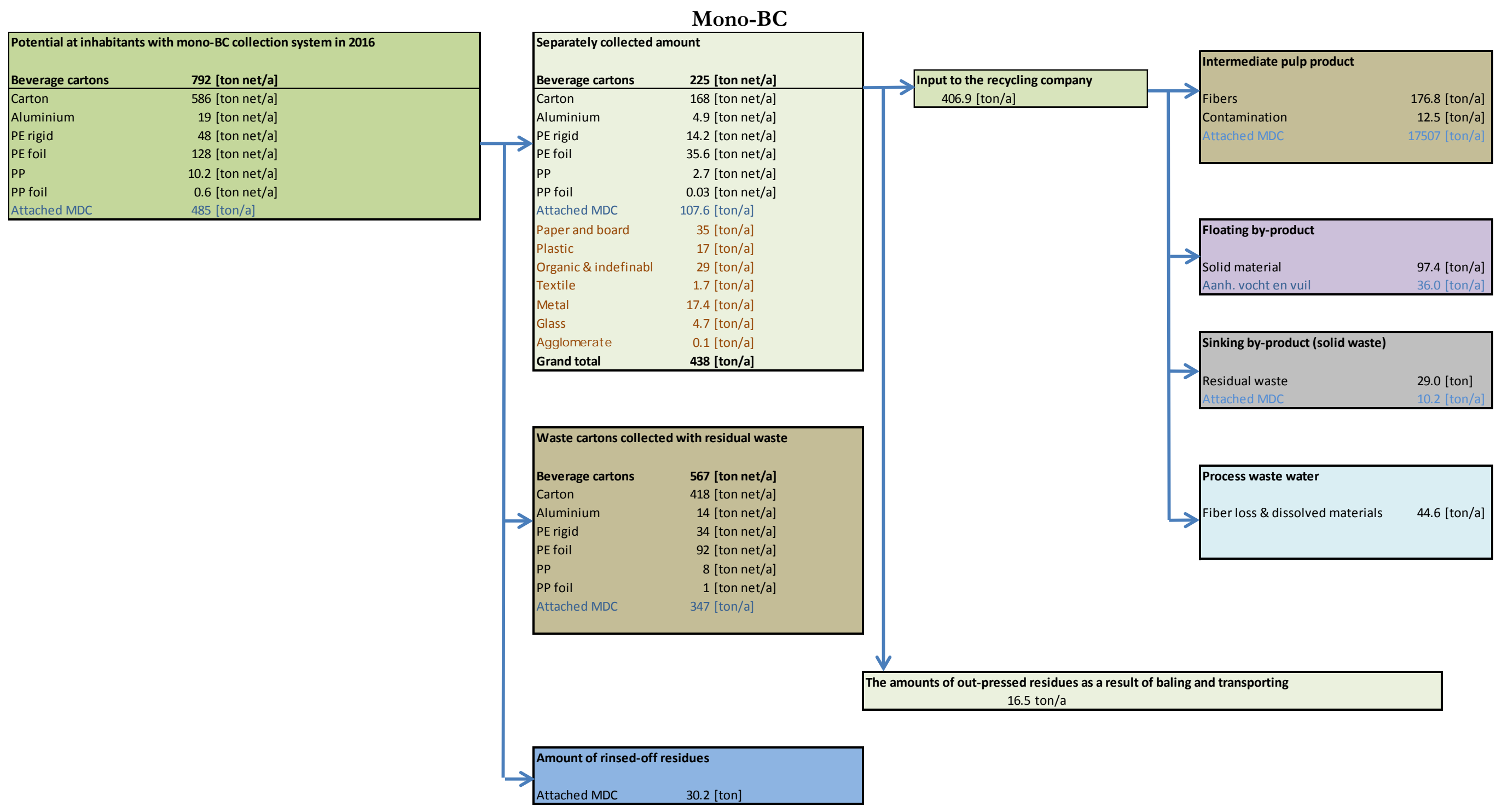


Mechanical recovery from MSW

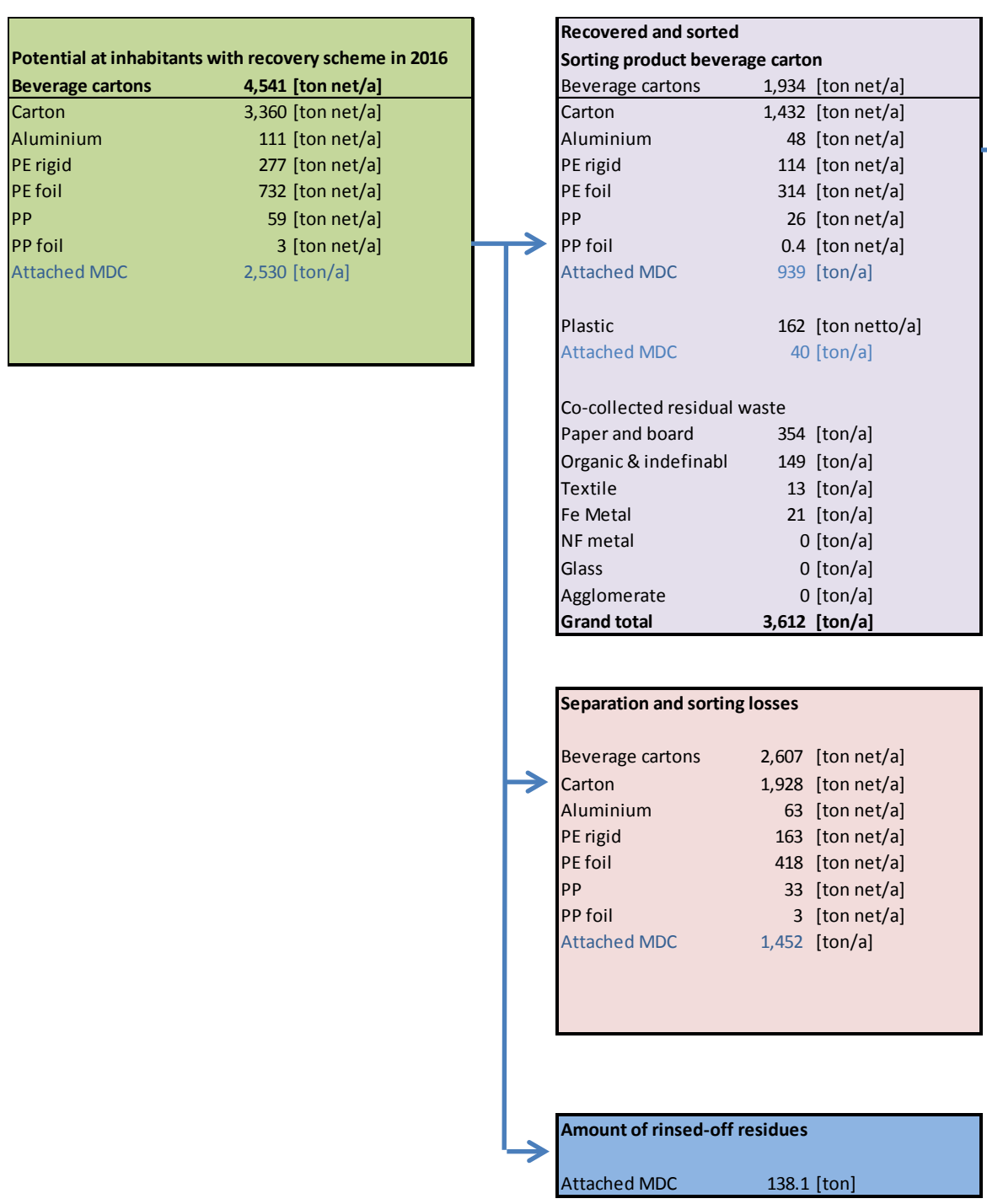

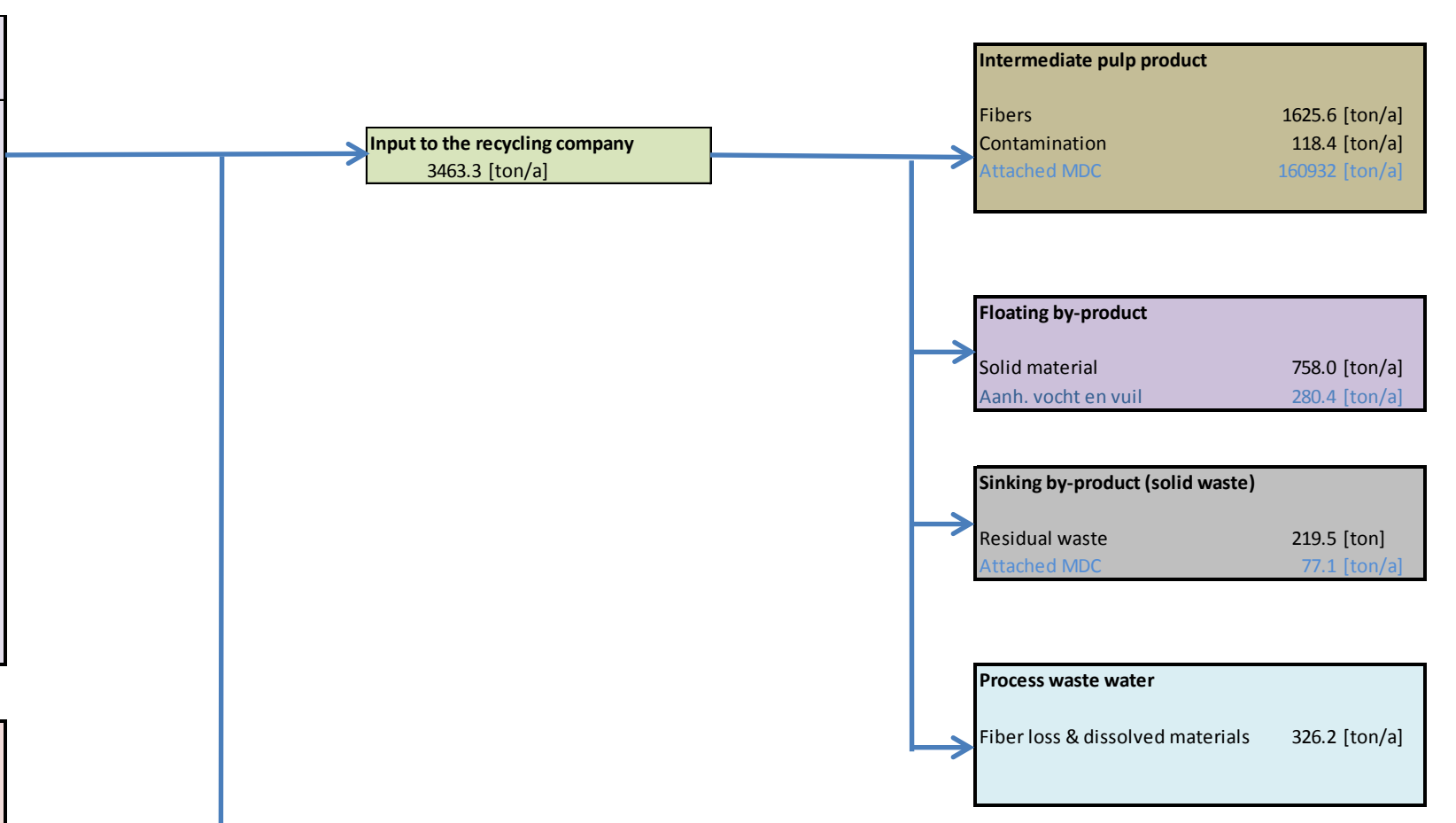


PD - sampled municipalities

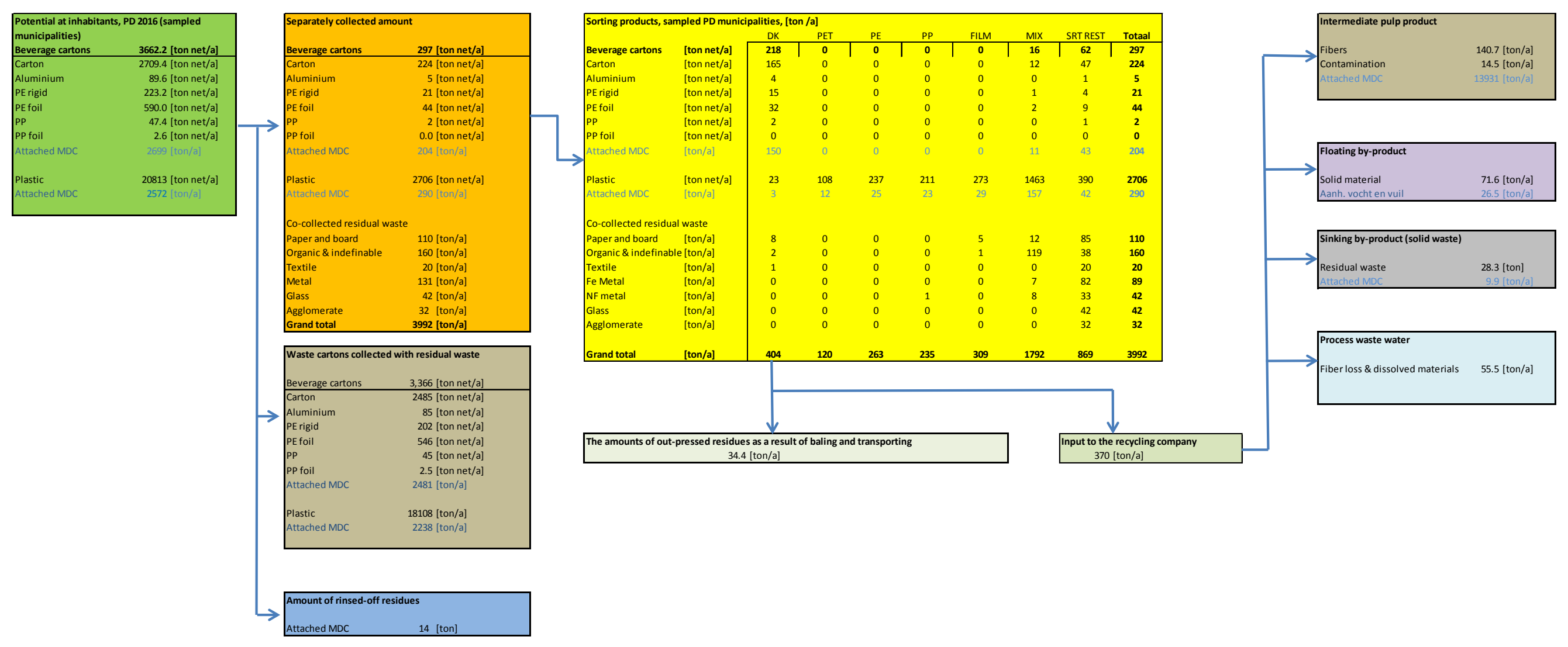


PMD - sampled municipalities

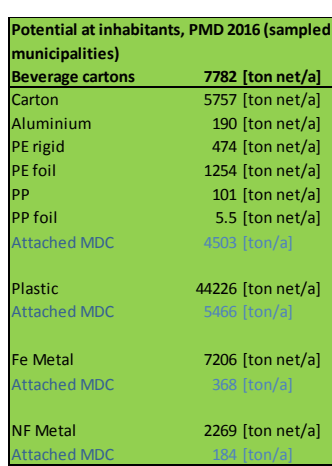


PD - whole PD category

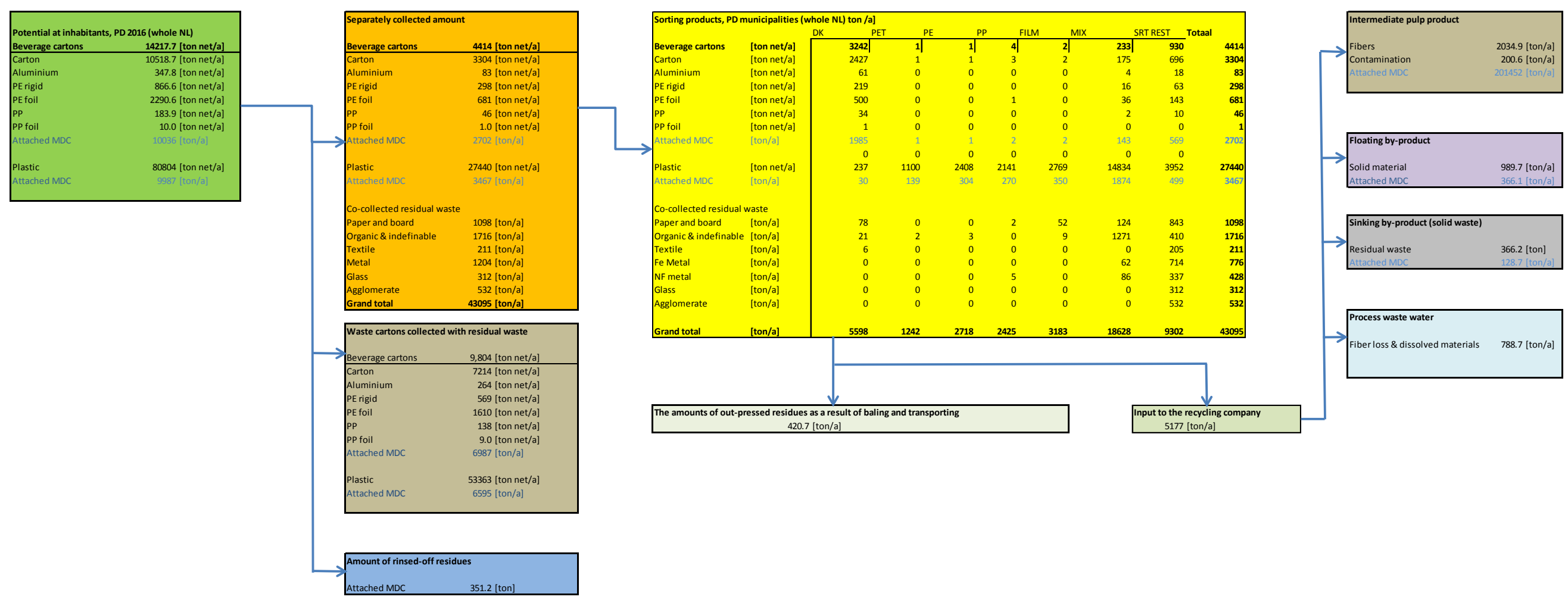


PMD - whole PMD category
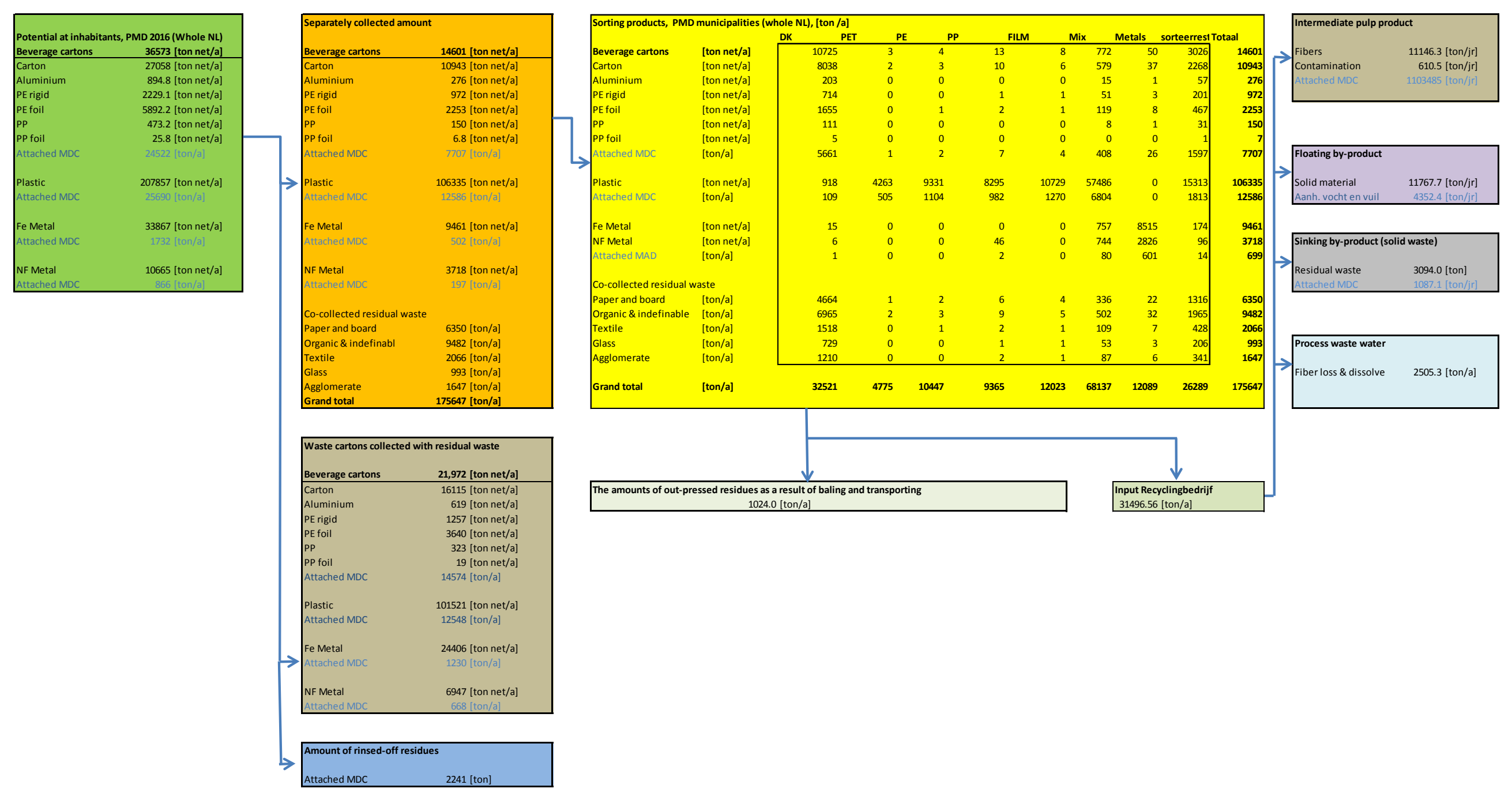


\section{Appendix D: Paper fibre fractionation results}

\section{Pulp Strength}

For the testing of the fibre strength in pulp-sheets the stored samples were pulped in a mechanical pulper (RAS-Pulper) for 10 minutes at a consistency of $2.5 \%$. The pulp was cleaned further from smaller size impurities with a Sommerville fractionator. A slit width of 0.15 mm was used. Hand-sheets were produced using a Rapid Köthen Sheet former. After conditioning, weight, thickness, Short Span Compressing Strength and tensile properties were determined according to ISO 536, ISO 534, ISO 1924-2 and ISO 9895.

\begin{tabular}{|c|c|c|c|c|c|c|c|c|c|c|c|}
\hline \multicolumn{12}{|c|}{ SP $(\mathrm{P}+\mathrm{PD}+\mathrm{PMD})$ storage at $4{ }^{\circ} \mathrm{C}$} \\
\hline Duration & Weeks & \multicolumn{2}{|c|}{0} & \multicolumn{2}{|c|}{0.5} & \multicolumn{2}{|c|}{1} & \multicolumn{2}{|c|}{2} & \multicolumn{2}{|c|}{4} \\
\hline Property & unit & & SD & & $\mathrm{SD}$ & & $\mathrm{SD}$ & & $\mathrm{SD}$ & & $\mathrm{SD}$ \\
\hline Grammage & $\mathrm{g} / \mathrm{m}^{2}$ & 83.4 & 0.7 & 90.5 & 2.5 & 82.8 & 1.1 & 93.1 & 0.8 & 87.9 & 3.2 \\
\hline Bulk & $\mathrm{cm}^{3} / \mathrm{g}$ & 1.71 & 0.07 & 1.71 & 0.11 & 1.69 & 0.06 & 1.72 & 0.03 & 1.76 & 0.07 \\
\hline Apparent sheet density & $\mathrm{g} / \mathrm{cm}^{3}$ & 0.58 & 0.02 & 0.59 & 0.04 & 0.59 & 0.02 & 0.58 & 0.01 & 0.57 & 0.02 \\
\hline Breaking length & $\mathrm{km}$ & 4.0 & 0.1 & 3.5 & 0.2 & 4.6 & 0.3 & 3.7 & 0.2 & 3.4 & 0.5 \\
\hline Tensile index & $\mathrm{Nm} / \mathrm{g}$ & 39.4 & 1.0 & 34.3 & 2.2 & 45.2 & 2.5 & 36.7 & 1.6 & 32.9 & 5.4 \\
\hline T.E.A.-index & $\mathrm{mJ} / \mathrm{G}$ & 438 & 22 & 336 & 36 & 575 & 80 & 449 & 82 & 396 & 58 \\
\hline E-modulus & $\mathrm{GPa}$ & 3.29 & 0.17 & 3.11 & 0.19 & 3.53 & 0.16 & 3.16 & 0.09 & 2.94 & 0.13 \\
\hline Strain & $\%$ & 1.6 & 0.1 & 1.4 & 0.1 & 1.9 & 0.1 & 1.7 & 0.2 & 1.6 & 0.1 \\
\hline
\end{tabular}

\begin{tabular}{|l|l|r|r|r|r|r|r|r|r|}
\hline \multicolumn{10}{|c|}{ SP (P+PD+PMD) storage at $20^{\circ} \mathbf{C}$} \\
\hline Duration & Weeks & \multicolumn{2}{|c|}{0.5} & \multicolumn{2}{|c|}{1} & \multicolumn{2}{|c|}{2} & \multicolumn{2}{|c|}{4} \\
\hline Property & unit & & SD & & SD & & SD & & SD \\
\hline Grammage & $\mathrm{g} / \mathrm{m}^{2}$ & 91.3 & 3.4 & 87.2 & 2.2 & 87.2 & 2.0 & 86.2 & 0.5 \\
\hline Bulk & $\mathrm{cm}^{3} / \mathrm{g}$ & 1.74 & 0.09 & 1.71 & 0.03 & 1.68 & 0.06 & 1.73 & 0.02 \\
\hline $\begin{array}{l}\text { Apparent sheet } \\
\text { density }\end{array}$ & $\mathrm{g} / \mathrm{cm}^{3}$ & 0.58 & 0.03 & 0.58 & 0.01 & 0.59 & 0.02 & 0.58 & 0.01 \\
\hline Breaking length & $\mathrm{km}$ & 3.0 & 0.7 & 3.6 & 0.2 & 3.9 & 0.3 & 3.4 & 0.3 \\
\hline Tensile index & $\mathrm{Nm} / \mathrm{g}$ & 28.9 & 6.9 & 34.9 & 1.9 & 38.7 & 2.5 & 33.0 & 2.9 \\
\hline T.E.A.-index & $\mathrm{mJ} / \mathrm{G}$ & 252 & 125 & 357 & 74 & 411 & 67 & 321 & 91 \\
\hline E-modulus & $\mathrm{GPa}$ & 2.83 & 0.40 & 3.10 & 0.07 & 3.43 & 0.23 & 3.05 & 0.14 \\
\hline Strain & $\%$ & 1.2 & 0.3 & 1.5 & 0.2 & 1.5 & 0.2 & 1.4 & 0.3 \\
\hline
\end{tabular}

(c) Wageningen Food \& Biobased Research, institute within the legal entity Stichting Wageningen Research 


\begin{tabular}{|l|l|r|r|r|r|r|r|r|r|r|}
\hline \multicolumn{9}{c|}{ SP (P+PD+PMD) storage at $40^{\circ} \mathbf{C}$} \\
\hline Duration & Weeks & \multicolumn{2}{c|}{0.5} & \multicolumn{2}{|c|}{1} & \multicolumn{2}{|c|}{2} & \multicolumn{2}{|c|}{4} \\
\hline Property & unit & & SD & & SD & & SD & & SD \\
\hline Grammage & $\mathrm{g} / \mathrm{m}^{2}$ & 97.2 & 0.8 & 104.9 & 6.0 & 86.8 & 3.9 & 93.0 & 0.5 \\
\hline Bulk & $\mathrm{cm}^{3} / \mathrm{g}$ & 1.67 & 0.02 & 1.71 & 0.02 & 1.73 & 0.12 & 1.78 & 0.02 \\
\hline $\begin{array}{l}\text { Apparent sheet } \\
\text { density }\end{array}$ & $\mathrm{g} / \mathrm{cm}^{3}$ & 0.60 & 0.01 & 0.59 & 0.01 & 0.58 & 0.04 & 0.56 & 0.01 \\
\hline Breaking length & $\mathrm{km}$ & 4.4 & 0.2 & 3.7 & 0.3 & 3.7 & 0.2 & 4.1 & 0.3 \\
\hline Tensile index & $\mathrm{Nm} / \mathrm{g}$ & 43.6 & 1.6 & 36.2 & 3.2 & 36.3 & 2.0 & 40.4 & 2.5 \\
\hline T.E.A.-index & $\mathrm{m} / \mathrm{G}$ & 575 & 52 & 400 & 30 & 409 & 23 & 494 & 86 \\
\hline E-modulus & $\mathrm{GPa}$ & 3.60 & 0.14 & 3.21 & 0.41 & 3.31 & 0.15 & 3.22 & 0.13 \\
\hline Strain & $\%$ & 1.9 & 0.1 & 1.6 & 0.2 & 1.6 & 0.0 & 1.7 & 0.2 \\
\hline
\end{tabular}




\begin{tabular}{|c|c|c|c|c|c|c|c|c|c|}
\hline \multicolumn{10}{|c|}{ SP (Recovery) storage at $4{ }^{\circ} \mathrm{C}$} \\
\hline Duration & Weeks & & & 1 & & 2 & & 4 & \\
\hline Property & unit & & $\mathrm{SD}$ & & $\mathrm{SD}$ & & $\mathrm{SD}$ & & $\mathrm{SD}$ \\
\hline Grammage & $\mathrm{g} / \mathrm{m}^{2}$ & 89.4 & 0.8 & 83.9 & 5.5 & 84.4 & 1.1 & 87.3 & 0.5 \\
\hline Bulk & $\mathrm{cm}^{3} / \mathrm{g}$ & 1.92 & 0.32 & 1.74 & 0.07 & 1.81 & 0.06 & 1.71 & 0.03 \\
\hline $\begin{array}{l}\text { Apparent sheet } \\
\text { density }\end{array}$ & $\mathrm{g} / \mathrm{cm}^{3}$ & 0.53 & 0.07 & 0.58 & 0.02 & 0.55 & 0.02 & 0.59 & 0.01 \\
\hline Breaking length & $\mathrm{km}$ & 2.6 & 0.1 & 3.9 & 0.5 & 2.9 & 0.1 & 3.8 & 0.2 \\
\hline Tensile index & $\mathrm{Nm} / \mathrm{g}$ & 25.3 & 0.9 & 38.0 & 5.2 & 28.3 & 0.7 & 37.2 & 1.7 \\
\hline T.E.A.-index & $\mathrm{mJ} / \mathrm{G}$ & 247 & 32 & 421 & 119 & 249 & 28 & 394 & 81 \\
\hline E-modulus & $\mathrm{GPa}$ & 2.25 & 0.36 & 3.28 & 0.28 & 2.55 & 0.13 & 3.19 & 0.08 \\
\hline Strain & $\%$ & 1.4 & 0.1 & 1.6 & 0.2 & 1.3 & 0.1 & 1.5 & 0.2 \\
\hline
\end{tabular}

\begin{tabular}{|l|l|r|r|r|r|r|r|}
\hline \multicolumn{7}{|c|}{ SP (Recovery) storage at $\mathbf{2 0}^{\circ} \mathbf{C}$} \\
\hline Duration & Weeks & \multicolumn{2}{|c|}{1} & \multicolumn{2}{|c|}{2} & \multicolumn{2}{|c|}{4} \\
\hline Property & unit & & \multicolumn{1}{l|}{ SD } & & \multicolumn{1}{l|}{ SD } & & SD \\
\hline Grammage & $\mathrm{g} / \mathrm{m}^{2}$ & 81.0 & 4.7 & 84.3 & 1.6 & 83.9 & 0.7 \\
\hline Bulk & $\mathrm{cm}^{3} / \mathrm{g}$ & 1.86 & 0.17 & 1.78 & 0.05 & 1.74 & 0.04 \\
\hline $\begin{array}{l}\text { Apparent sheet } \\
\text { density }\end{array}$ & $\mathrm{g} / \mathrm{cm}^{3}$ & 0.54 & 0.05 & 0.56 & 0.01 & 0.57 & 0.01 \\
\hline Breaking length & $\mathrm{km}$ & 3.1 & 0.5 & 2.9 & 0.1 & 3.8 & 0.3 \\
\hline Tensile index & $\mathrm{Nm} / \mathrm{g}$ & 30.9 & 4.6 & 28.4 & 0.9 & 36.8 & 3.2 \\
\hline T.E.A.-index & $\mathrm{mJ} / \mathrm{G}$ & 340 & 74 & 254 & 41 & 400 & 119 \\
\hline E-modulus & $\mathrm{GPa}$ & 2.58 & 0.24 & 2.56 & 0.07 & 3.18 & 0.17 \\
\hline Strain & $\%$ & 1.6 & 0.1 & 1.3 & 0.1 & 1.6 & 0.3 \\
\hline
\end{tabular}




\begin{tabular}{|l|l|r|r|r|r|r|r|}
\hline \multicolumn{7}{|c|}{ SP (Recovery) storage at $\mathbf{4 0}^{\circ} \mathbf{C}$} \\
\hline Duration & Weeks & \multicolumn{1}{c|}{1} & \multicolumn{2}{|c|}{2} & \multicolumn{2}{|c|}{4} \\
\hline Property & unit & & $\mathrm{SD}$ & & $\mathrm{SD}$ & & $\mathrm{SD}$ \\
\hline Grammage & $\mathrm{g} / \mathrm{m}^{2}$ & 85.7 & 0.5 & 83.1 & 0.5 & 81.4 & 0.8 \\
\hline Bulk & $\mathrm{cm}^{3} / \mathrm{g}$ & 1.79 & 0.06 & 1.84 & 0.05 & 1.87 & 0.06 \\
\hline $\begin{array}{l}\text { Apparent sheet } \\
\text { density }\end{array}$ & $\mathrm{g} / \mathrm{cm}^{3}$ & 0.56 & 0.02 & 0.54 & 0.02 & 0.53 & 0.02 \\
\hline Breaking length & $\mathrm{km}$ & 3.0 & 0.1 & 3.2 & 0.1 & 3.0 & 0.2 \\
\hline Tensile index & $\mathrm{Nm} / \mathrm{g}$ & 29.5 & 1.1 & 31.3 & 1.4 & 29.3 & 2.1 \\
\hline T.E.A.-index & $\mathrm{mJ} / \mathrm{G}$ & 269 & 46 & 288 & 61 & 282 & 41 \\
\hline E-modulus & $\mathrm{GPa}$ & 2.65 & 0.12 & 2.71 & 0.09 & 2.41 & 0.19 \\
\hline Strain & $\%$ & 1.3 & 0.2 & 1.4 & 0.2 & 1.4 & 0.1 \\
\hline
\end{tabular}


Fibre length characterisation

For the length qualification the stored samples were pulped in in a mechanical pulper (RAS-Pulper) for 10 minutes at a consistency of 2,5\%. Part of the pulped sample was fractionated using a Sommerville fractionator (slit width of $0.15 \mathrm{~mm}$ ) followed by a Bauer-McNett classifier. This resulted in five different fractions: Particles with a width $>0.15 \mathrm{~mm}$. And four different fibre length fractions: $>1.19 \mathrm{~mm},>0.595 \mathrm{~mm},>0.149 \mathrm{~mm},>0.074 \mathrm{~mm}$. All particles smaller $/$ shorter than $0.074 \mathrm{~mm}$ were not determined.

\begin{tabular}{|l|c|c|c|c|c|c|c|}
\hline & \multicolumn{3}{|c|}{ Storage conditions } & \multicolumn{5}{c|}{ Mass fractions [dry matter wt\%] } \\
\hline & $\begin{array}{c}\text { Temperature } \\
{\left[{ }^{\circ} \mathrm{C}\right]}\end{array}$ & $\begin{array}{c}\text { Duration } \\
{[\text { weeks] }}\end{array}$ & $\begin{array}{l}\text { Diameter } \\
{[\mathrm{mm}]}\end{array}$ & \multicolumn{4}{|c|}{$\begin{array}{c}\text { Length } \\
{[\mathrm{mm}]}\end{array}$} \\
\hline & & & $>0.15$ & $>1.19$ & $>0.595$ & $>0.149$ & $>0.074$ \\
\hline $\begin{array}{l}\text { SP } \\
(\mathrm{P}+\mathrm{PD}+\mathrm{PMD})\end{array}$ & 4 & 0.5 & 30.3 & 36.2 & 22.7 & 9.3 & 1.4 \\
\hline & 4 & 2 & 40.4 & 28.2 & 24.0 & 6.9 & 0.4 \\
\hline & 4 & 4 & 30.9 & 29.2 & 26.0 & 13.3 & 0.5 \\
\hline & 20 & 0.5 & 30.5 & 33.3 & 22.1 & 13.0 & 1.0 \\
\hline & 20 & 2 & 34.5 & 28.4 & 24.3 & 12.3 & 0.5 \\
\hline & 20 & 4 & 33.6 & 33.1 & 21.0 & 11.9 & 0.4 \\
\hline & 40 & 0.5 & 30.9 & 31.4 & 22.7 & 14.3 & 0.8 \\
\hline & 40 & 2 & 30.7 & 32.5 & 24.3 & 11.9 & 0.6 \\
\hline & 40 & 4 & 29.0 & 35.5 & 22.8 & 12.3 & 0.4 \\
\hline & - & 0 & 29.8 & 36.3 & 21.7 & 11.8 & 0.5 \\
\hline & 4 & 1 & 32.1 & 30.2 & 24.0 & 13.0 & 0.6 \\
\hline & 4 & 2 & 35.2 & 29.2 & 21.8 & 13.5 & 0.3 \\
\hline & 4 & 4 & 29.6 & 33.2 & 23.9 & 12.7 & 0.6 \\
\hline & 20 & 1 & 27.2 & 36.8 & 22.8 & 13.0 & 0.3 \\
\hline & 20 & 2 & 28.1 & 33.0 & 24.4 & 14.2 & 0.3 \\
\hline & 20 & 4 & 37.0 & 29.7 & 20.8 & 12.0 & 0.5 \\
\hline & 40 & 1 & 28.8 & 32.6 & 24.2 & 13.9 & 0.5 \\
\hline & 40 & 2 & 29.4 & 34.8 & 22.9 & 12.6 & 0.3 \\
\hline & 4 & 4 & 30.0 & 35.8 & 21.1 & 12.8 & 0.3 \\
\hline
\end{tabular}




\section{Appendix E: Categorisation of municipalities}

\begin{tabular}{|llc|}
\hline \multicolumn{3}{|l|}{ Mono-P (no BC) } \\
\hline System & Municipality & Inhabitants \\
\hline PA, $\geq 50 \%$ HRB & - & - \\
\hline PA, $<50 \%$ HRB & Aalsmeer & 31299 \\
& Boxtel & 30406 \\
& Heemstede & 26766 \\
& Hellendoorn & 35651 \\
& Oegstgeest & 23209 \\
& Sint Michielsgestel & 28403 \\
Zundert & 21488 \\
\hline NP, $\geq 50 \%$ HRB & Leiden & 122561 \\
& Vlaardingen & 71808 \\
\hline NP, $<50 \%$ HRB & Barneveld & 55441 \\
& Best & 28976 \\
& Brielle & 16640 \\
Dongen & 25413 \\
& Edam-Volendam & 35465 \\
Heerhugowaard & 53927 \\
& Hulst & 27372 \\
Kaag en Braassem & 26108 \\
Leiderdorp & 26968 \\
Nissewaard & 85293 \\
Noordwijk & 25760 \\
Oudewater & 10049 \\
Pekela & 12641 \\
Slochteren & 15698 \\
Uden & 41247 \\
Uitgeest & 13360 \\
Valkenswaard & 30262 \\
Vlissingen & 44451 \\
Voorschoten & 25211 \\
Westland & 104960 \\
\hline
\end{tabular}

\begin{tabular}{|lcc|}
\hline \multicolumn{3}{|c|}{ Mono BC } \\
\hline System & Municipality & Inhabitants \\
\hline DO, PA, $\geq 50 \%$ HRB & - & - \\
\hline DO, PA, $<50 \%$ HRB & Beesel & 13388 \\
& Haaren & 13570 \\
& Overbetuwe & 47002 \\
& Venray & 43291 \\
\hline DO, NP, $\geq 50 \%$ HRB & - & - \\
\hline DO, NP $<50 \%$ HRB & - & - \\
\hline $\mathrm{KS}, \mathrm{PA} \geq 50 \%$ HRB & - & - \\
\hline $\mathrm{KS}, \mathrm{PA}<50 \%$ HRB & Sint-Oedenrode & 17896 \\
\hline $\mathrm{KS}, \mathrm{NP}, \geq 50 \%$ HRB & - & - \\
\hline $\mathrm{KS}, \mathrm{NP},<50 \%$ HRB & Echt-Susteren & 31943 \\
& Roermond & 57010 \\
\hline $\mathrm{CO}, \mathrm{PA}, \geq 50 \%$ HRB & - & - \\
\hline $\mathrm{CO}, \mathrm{PA},<50 \%$ HRB & - & - \\
\hline $\mathrm{CO}, \mathrm{NP}, \geq 50 \%$ HRB & - & - \\
\hline $\mathrm{CO}, \mathrm{NP},<50 \%$ HRB & - & - \\
\hline
\end{tabular}

\begin{tabular}{|c|c|c|}
\hline \multicolumn{3}{|c|}{ Recovery } \\
\hline System & Municipality & Inhabitants \\
\hline $\mathrm{DO}, \geq 50 \% \mathrm{HRB}$ & - & - \\
\hline \multirow[t]{8}{*}{$\mathrm{DO},<50 \% \mathrm{HRB}$} & De Friese Meren & 51265 \\
\hline & De Marne & 10101 \\
\hline & Haren & 19076 \\
\hline & Heerenveen & 50290 \\
\hline & Ooststellingwerf & 25571 \\
\hline & Opsterland & 29830 \\
\hline & Ten Boer & 7352 \\
\hline & Winsum & 13633 \\
\hline \multirow[t]{2}{*}{$\mathrm{NP}, \geq 50 \% \mathrm{HRB}$} & Groningen & 200952 \\
\hline & Eindhoven & 224755 \\
\hline \multirow[t]{29}{*}{$N P,<50 \% \mathrm{HRB}$} & Achtkarspelen & 28007 \\
\hline & Ameland & 3611 \\
\hline & Appingedam & 12001 \\
\hline & Bedum & 10433 \\
\hline & Dantumadeel & 19015 \\
\hline & Delfzijl & 25068 \\
\hline & Dongeradeel & 23932 \\
\hline & Eemsmond & 15815 \\
\hline & Elburg & 22929 \\
\hline & Ermelo & 26507 \\
\hline & Ferwerderadiel & 8701 \\
\hline & Franekeradeel & 20265 \\
\hline & Harderwijk & 45966 \\
\hline & Harlingen & 15813 \\
\hline & Het Bildt & 10525 \\
\hline & Kollumerland en Nieuwkruisland & 12811 \\
\hline & Leeuwarden & 107897 \\
\hline & Leeuwarderadeel & 10175 \\
\hline & Littenseradiel & 10833 \\
\hline & Loppersum & 10042 \\
\hline & Menameradiel & 13543 \\
\hline & Nunspeet & 26835 \\
\hline & Oldebroek & 23104 \\
\hline & Schiermonnikoog & 919 \\
\hline & Terschelling & 4870 \\
\hline & Tytsjerksteradiel & 32077 \\
\hline & Vlieland & 1083 \\
\hline & Weststellingwerf & 25520 \\
\hline & Zuidwest-Friesland & 84048 \\
\hline
\end{tabular}




\begin{tabular}{|c|c|c|c|c|c|c|c|c|}
\hline \multicolumn{9}{|c|}{ PD collection } \\
\hline System & Municipality & Inhabitants & System & Municipality & Inhabitants & System & Municipality & Inhabitants \\
\hline $\mathrm{DO}, \mathrm{PA}, \geq 50 \% \mathrm{HRB}$ & 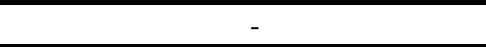 & - & \multirow{31}{*}{$\mathrm{KS}, \mathrm{PA},<50 \% \mathrm{HRB}$} & Aalburg & 13038 & $\mathrm{KS}, \mathrm{NP}, \geq 50 \% \mathrm{HRB}$ & - & - \\
\hline \multirow[t]{6}{*}{$\mathrm{DO}, \mathrm{PA},<50 \% \mathrm{HRB}$} & Bergen op Zoom & 66237 & & Bernheze & 29880 & $\mathrm{KS}, \mathrm{NP}<50 \% \mathrm{HRB}$ & Borsele & 22612 \\
\hline & Haarlemmermeer & 144518 & & Bloemendaal & 22296 & & Krimpenerwaard & 54653 \\
\hline & Halderberge & 29531 & & Buren & 26202 & & Moerdijk & 36762 \\
\hline & Nijkerk & 41199 & & Culemborg & 27644 & & Nieuwkoop & 27433 \\
\hline & Schouwen-Duiveland & 33735 & & Geldermalsen & 26346 & & Noord-Beveland & 7421 \\
\hline & Vught & 25973 & & Grootegast & 12155 & & Sluis & 23639 \\
\hline \multirow[t]{4}{*}{$\mathrm{DO}, \mathrm{NP}, \geq 50 \% \mathrm{HRB}$} & Amsterdam & 833624 & & Helmond & 90127 & & Waddinxveen & 26072 \\
\hline & Diemen & 26840 & & Hoogezand-Sappemeer & 34177 & & Woudenberg & 12550 \\
\hline & Rotterdam & 629606 & & Kapelle & 12639 & & Zandvoort & 16792 \\
\hline & Schiedam & 77108 & & Leek & 19536 & $\mathrm{CO}, \mathrm{PA}, \geq 50 \% \mathrm{HRB}$ & - & - \\
\hline \multirow[t]{10}{*}{$\mathrm{DO}, \mathrm{NP},<50 \% \mathrm{HRB}$} & Beemster & 8958 & & Lingewaal & 11112 & $\mathrm{CO}, \mathrm{PA},<50 \% \mathrm{HRB}$ & - & - \\
\hline & Bergen NH & 29943 & & Maasdriel & 24084 & $\mathrm{CO}, \mathrm{NP}, \geq 50 \% \mathrm{HRB}$ & - & - \\
\hline & Beverwijk & 40318 & & Marum & 10305 & $\mathrm{CO}, \mathrm{NP},<50 \% \mathrm{HRB}$ & Breda & 181611 \\
\hline & Bodegraven-Reeuwijk & 33451 & & Menterwolde & 12233 & & Geertruidenberg & 21630 \\
\hline & Lelystad & 76792 & & Neerijnen & 12122 & & & \\
\hline & Middelburg & 47873 & & Oldambt & 38228 & & & \\
\hline & s-Hertogenbosch & 151608 & & Roerdalen & 20686 & & & \\
\hline & Steenbergen & 23477 & & Roosendaal & 76960 & & & \\
\hline & Terneuzen & 54657 & & Rucphen & 22276 & & & \\
\hline & Zaanstad & 152466 & & Schijndel & 23625 & & & \\
\hline \multirow[t]{10}{*}{$\mathrm{KS}, \mathrm{PA}, \geq 50 \% \mathrm{HRB}$} & - & - & & Stadskanaal & 32621 & & & \\
\hline & & & & Tiel & 41510 & & & \\
\hline & & & & Tynaarlo & 32804 & & & \\
\hline & & & & Veghel & 38078 & & & \\
\hline & & & & Werkendam & 26527 & & & \\
\hline & & & & West Maas en Waal & 18693 & & & \\
\hline & & & & Woudrichem & 14518 & & & \\
\hline & & & & Zaltbommel & 27543 & & & \\
\hline & & & & Zuidhorn & 18794 & & & \\
\hline & & & & Zuidplas & 40937 & & & \\
\hline
\end{tabular}




\begin{tabular}{|c|c|c|c|c|c|}
\hline \multicolumn{6}{|c|}{ PMD collection } \\
\hline System & Municipality & Inhabitants & System & Municipality & Inhabitants \\
\hline $\mathrm{DO}, \mathrm{PA}, \geq 50 \% \mathrm{HRB}$ & - & - & \multirow[t]{6}{*}{$\mathrm{KS}, \mathrm{NP}, \geq 50 \% \mathrm{HRB}$} & Amstelveen & 88602 \\
\hline \multirow[t]{7}{*}{$\mathrm{DO}, \mathrm{PA},<50 \% \mathrm{HRB}$} & Haaksbergen & 24332 & & Capelle aan den IJssel & 66486 \\
\hline & Leudal & 36140 & & Delft & 101034 \\
\hline & Maasgouw & 23757 & & Leidschendam-Voorburg & 74223 \\
\hline & Maastricht & 122533 & & Utrecht & 338967 \\
\hline & Nederweert & 16793 & & Wageningen & 37837 \\
\hline & Twenterand & 33846 & $\mathrm{CO}, \mathrm{PA}, \geq 50 \% \mathrm{HRB}$ & Eindhoven (Bennekel en deel van Blaarthem) & - \\
\hline & Zevenaar & 32269 & \multirow[t]{8}{*}{$\mathrm{CO}, \mathrm{PA},<50 \% \mathrm{HRB}$} & Apeldoorn & 159025 \\
\hline \multirow[t]{3}{*}{$\mathrm{DO}, \mathrm{NP}, \geq 50 \% \mathrm{HRB}$} & Maassluis & 32292 & & Bronckhorst & 36510 \\
\hline & Rijswijk & 49328 & & Etten-Leur & 42832 \\
\hline & s-Gravenhage & 519988 & & Gennep & 17085 \\
\hline \multirow[t]{22}{*}{$\mathrm{DO}, \mathrm{NP},<50 \% \mathrm{HRB}$} & Almelo & 72425 & & Hengelo & 81075 \\
\hline & Almere & 198145 & & Schinnen & 12960 \\
\hline & Amersfoort & 153602 & & Sittard-Geleen & 93555 \\
\hline & Barendrecht & 47861 & & Stein & 25064 \\
\hline & Borne & 22343 & $\mathrm{CO}, \mathrm{NP}, \geq 50 \% \mathrm{HRB}$ & Weesp & 18572 \\
\hline & Goirle & 23111 & \multirow[t]{23}{*}{$\mathrm{CO}, \mathrm{NP},<50 \% \mathrm{HRB}$} & Alblasserdam & 19955 \\
\hline & Haarlem & 158140 & & Alkmaar & 107615 \\
\hline & Hardinxveld-Giessendam & 17774 & & Blaricum & 9622 \\
\hline & Heemskerk & 39299 & & Coevorden & 35381 \\
\hline & Hellevoetsluis & 38634 & & Emmen & 107584 \\
\hline & Katwijk & 64239 & & Epe & 32282 \\
\hline & Leusden & 29309 & & Giessenlanden & 14544 \\
\hline & Noordwijkerhout & 16140 & & Gooise Meren & 56696 \\
\hline & Ouder-Amstel & 13411 & & Gorinchem & 35260 \\
\hline & Pijnacker-Nootdorp & 51894 & & Hilversum & 87830 \\
\hline & Purmerend & 79889 & & Huizen & 41373 \\
\hline & Velsen & 67448 & & Laren & 10956 \\
\hline & Waterland & 17304 & & Oss & 90003 \\
\hline & Weert & 49100 & & Papendrecht & 32248 \\
\hline & Wijk bij Duurstede & 23384 & & Peel en Maas & 43316 \\
\hline & Zederik & 13718 & & Rijssen-Holten & 37875 \\
\hline & Zeewolde & 22113 & & Stichtse Vecht & 64061 \\
\hline \multirow[t]{6}{*}{$\mathrm{KS}, \mathrm{PA}, \geq 50 \% \mathrm{HRB}$} & - & - & & Strijen & 8766 \\
\hline & & & & Tilburg & 212941 \\
\hline & & & & Wijdemeren & 23275 \\
\hline & & & & Woerden & 51161 \\
\hline & & & & Zwijndrecht & 44454 \\
\hline & & & & Zwolle & 124896 \\
\hline
\end{tabular}


PMD collection

\begin{tabular}{|c|c|c|c|c|c|c|c|c|}
\hline System & Municipality & Inhabitants & System & Municipality & Inhabitants & System & Municipality & Inhabitants \\
\hline \multirow[t]{32}{*}{$\mathrm{KS}, \mathrm{PA},<50 \% \mathrm{HRB}$} & Aa en Hunze & 25243 & $\mathrm{KS}, \mathrm{PA},<50 \% \mathrm{HRB}$ & Gemert-Bakel & 29647 & $\mathrm{KS}, \mathrm{PA},<50 \% \mathrm{HRB}$ & Ommen & 17696 \\
\hline & Aalten & 26912 & & Gilze en Rijen & 26152 & & Onderbanken & 7869 \\
\hline & Asten & 16580 & & Grave & 12643 & & Oost Gelre & 29537 \\
\hline & Baarle-Nassau & 6611 & & Hattem & 11890 & & Oosterhout & 54018 \\
\hline & Beek & 16068 & & Heerde & 18556 & & Oud-Beijerland & 23851 \\
\hline & Bellingwedde & 8971 & & Heerlen & 87406 & & Putten & 24516 \\
\hline & Berg en dal & 34574 & & Heeze-Leende & 15650 & & Raalte & 36700 \\
\hline & Bergeijk & 18253 & & Heumen & 16360 & & Reusel-De Mierden & 12811 \\
\hline & Bergen (L.) & 13090 & & Heusden & 43274 & & Rheden & 43824 \\
\hline & Berkelland & 44437 & & Hilvarenbeek & 15164 & & Rijnwaarden & 10866 \\
\hline & Beuningen & 25289 & & Hof van Twente & 34881 & & Simpelveld & 10741 \\
\hline & Binnenmaas & 28771 & & Horst aan de Maas & 41675 & & Sint Anthonis & 11594 \\
\hline & Bladel & 19966 & & Kampen & 51950 & & Someren & 18914 \\
\hline & Boekel & 10254 & & Kerkrade & 46023 & & Staphorst & 16544 \\
\hline & Borger-Odoorn & 25371 & & Korendijk & 10825 & & Steenwijkerland & 43333 \\
\hline & Boxmeer & 28465 & & Laarbeek & 21965 & & Teylingen & 36013 \\
\hline & Brummen & 20938 & & Landgraaf & 37465 & & Tubbergen & 21120 \\
\hline & Brunssum & 28448 & & Lingewaard & 45950 & & Vaals & 9632 \\
\hline & Cranendonck & 20660 & & Lisse & 22606 & & Valkenburg aan de Geul & 16518 \\
\hline & Cromstrijen & 12755 & & Lochem & 33333 & & Veenendaal & 63816 \\
\hline & Cuijk & 24608 & & Lopik & 14156 & & Vianen & 19513 \\
\hline & Dalfsen & 27916 & & Losser & 22444 & & Voerendaal & 12482 \\
\hline & Deurne & 31878 & & Meerssen & 19040 & & Voorst & 23984 \\
\hline & Deventer & 98869 & & Mill en Sint Hubert & 10801 & & Waalwijk & 47021 \\
\hline & Dinkelland & 26120 & & Montferland & 35173 & & Westervoort & 15001 \\
\hline & Doesburg & 11336 & & Mook en Middelaar & 7755 & & Wierden & 23952 \\
\hline & Drimmelen & 26815 & & Nijmegen & 172064 & & Wijchen & 40814 \\
\hline & Druten & 18407 & & Nuenen, Gerwen en Nederwetten & 22763 & & Winterswijk & 28939 \\
\hline & Duiven & 25433 & & Nuth & 15425 & & Zoeterwoude & 8119 \\
\hline & Eersel & 18551 & & Oirschot & 18199 & & Zutphen & 46997 \\
\hline & Eijsden-Margraten & 25123 & & Oisterwijk & 25835 & & Zwartewaterland & 22278 \\
\hline & Geldrop-Mierlo & 38893 & & Olst-Wijhe & 17886 & & & \\
\hline
\end{tabular}




\begin{tabular}{|c|c|c|c|c|c|c|c|c|}
\hline \multicolumn{9}{|c|}{ PMD collection } \\
\hline System & Municipality & Inhabitants & System & Municipality & Inhabitants & System & Municipality & Inhabitants \\
\hline \multirow[t]{26}{*}{$\mathrm{KS}, \mathrm{NP},<50 \% \mathrm{HRB}$} & Albrandswaard & 24985 & $\mathrm{KS}, \mathrm{NP},<50 \% \mathrm{HRB}$ & Hoogeveen & 55240 & $K S, N P,<50 \%$ HRB & Renswoude & 5051 \\
\hline & Alphen aan den Rijn & 107960 & & Hoorn & 72172 & & Rhenen & 19400 \\
\hline & Arnhem & 153818 & & IJsselstein & 34101 & & Rozendaal & 1498 \\
\hline & Assen & 67061 & & Koggenland & 22471 & & Schagen & 46159 \\
\hline & Baarn & 24521 & & Krimpen aan den IJssel & 29054 & & Scherpenzeel & 9529 \\
\hline & Bunnik & 14773 & & Landerd & 15303 & & Sliedrecht & 24968 \\
\hline & Bunschoten & 20823 & & Landsmeer & 10977 & & Smallingerland & 55439 \\
\hline & Castricum & 34604 & & Langedijk & 27447 & & Soest & 45487 \\
\hline & De Bilt & 42375 & & Lansingerland & 59035 & & Son en Breugel & 16425 \\
\hline & De Ronde Venen & 42576 & & Leerdam & 20711 & & Stede Broec & 21493 \\
\hline & De Wolden & 23722 & & Loon op Zand & 22929 & & Texel & 13574 \\
\hline & Den Helder & 56275 & & Medemblik & 43725 & & Uithoorn & 29181 \\
\hline & Doetinchem & 56827 & & Meppel & 32794 & & Urk & 19987 \\
\hline & Dordrecht & 118801 & & Midden-Delfland & 18873 & & Utrechtse Heuvelrug & 48506 \\
\hline & Dronten & 40592 & & Molenwaard & 29067 & & Veere & 21960 \\
\hline & Ede & 112427 & & Montfoort & 13783 & & Veldhoven & 44317 \\
\hline & Eemnes & 8877 & & Nieuwegein & 61749 & & Venlo & 100371 \\
\hline & Enkhuizen & 18455 & & Noordenveld & 31039 & & Vlagtwedde & 16422 \\
\hline & Enschede & 158351 & & Noordoostpolder & 46439 & & Waalre & 17023 \\
\hline & Goeree-Overflakkee & 48321 & & Oldenzaal & 32110 & & Wassenaar & 25885 \\
\hline & Goes & 37207 & & Oostzaan & 9504 & & Westerveld & 18940 \\
\hline & Gulpen-Wittem & 14508 & & Opmeer & 11336 & & Westvoorne & 14197 \\
\hline & Heiloo & 22689 & & Oude IJsselstreek & 39657 & & Wormerland & 15664 \\
\hline & Hendrik-Ido-Ambacht & 29408 & & Reimerswaal & 22265 & & Zeist & 62258 \\
\hline & Hillegom & 21089 & & Renkum & 31254 & & Zoetermeer & 124107 \\
\hline & Hollands Kroon & 47546 & & & & & & \\
\hline
\end{tabular}

